Prepared in cooperation with the New York State Department of Environmental Conservation

\title{
Analysis of Remedial Scenarios Affecting Plume Movement Through a Sole-Source Aquifer System, Southeastern Nassau County, New York
}

Scientific Investigations Report 2020-5090 



\section{Analysis of Remedial Scenarios Affecting Plume Movement Through a Sole-Source Aquifer System, Southeastern Nassau County, New York}

By Paul E. Misut, Donald Walter, Christopher Schubert, and Sarken Dressler

Prepared in cooperation with the

New York State Department of Environmental Conservation

Scientific Investigations Report 2020-5090 


\title{
U.S. Department of the Interior \\ DAVID BERNHARDT, Secretary
}

\author{
U.S. Geological Survey \\ James F. Reilly II, Director
}

U.S. Geological Survey, Reston, Virginia: 2020

For more information on the USGS - the Federal source for science about the Earth, its natural and living resources, natural hazards, and the environment-visit https://www.usgs.gov or call 1-888-ASK-USGS.

For an overview of USGS information products, including maps, imagery, and publications, visit https://store.usgs.gov/.

Any use of trade, firm, or product names is for descriptive purposes only and does not imply endorsement by the U.S. Government.

Although this information product, for the most part, is in the public domain, it also may contain copyrighted materials as noted in the text. Permission to reproduce copyrighted items must be secured from the copyright owner.

Suggested citation:

Misut, P.E., Walter, D., Schubert, C., and Dressler, S., 2020, Analysis of remedial scenarios affecting plume movement through a sole-source aquifer system, southeastern Nassau County, New York: U.S. Geological Survey Scientific Investigations Report 2020-5090, 83 p., https://doi.org/10.3133/sir20205090.

Data associated with this publication:

Misut, P.E., 2020, MODFLOW-NWT and MODPATH6 model use to analyze remedial scenarios affecting plume movement through a sole-source aquifer system, southeastern Nassau County, New York: U.S. Geological Survey data release, https://doi.org/10.5066/P9D0B08N.

ISSN 2328-0328 (online) 


\section{Contents}

Abstract

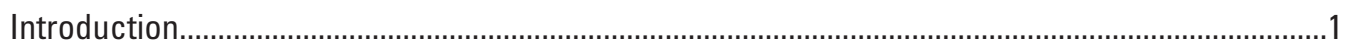

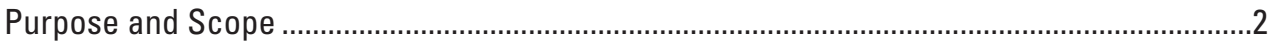

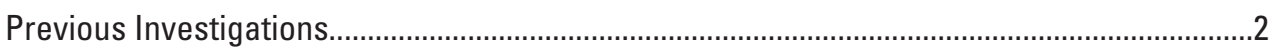

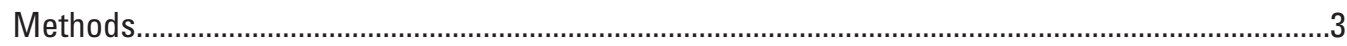

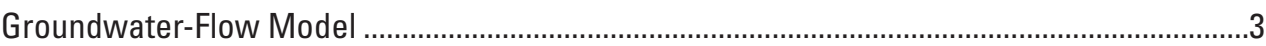

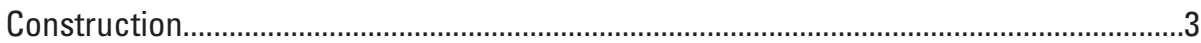

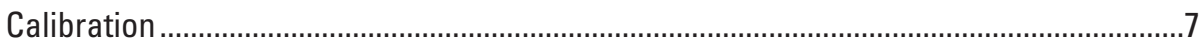

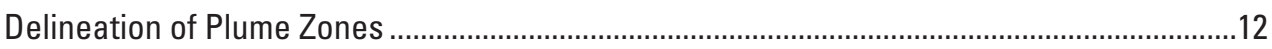

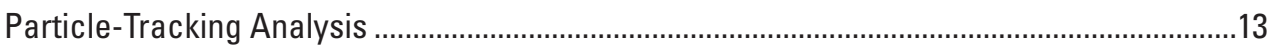

Analysis of Remedial Scenarios Affecting Plume Movement.........................................................26

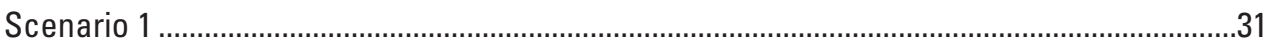

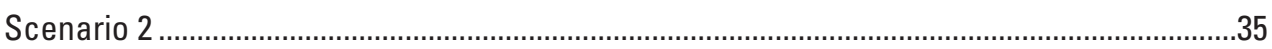

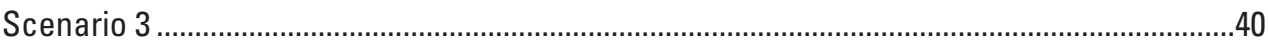

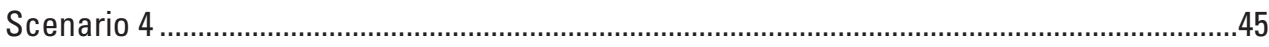

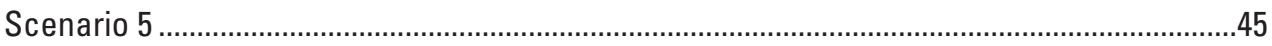

Limitations of Analysis ....................................................................................................

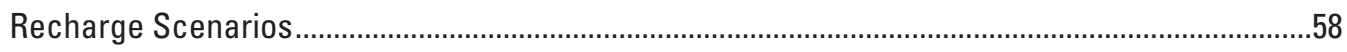

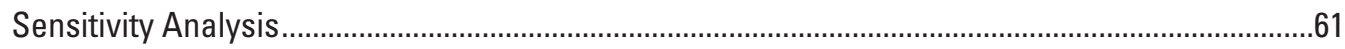

Summary

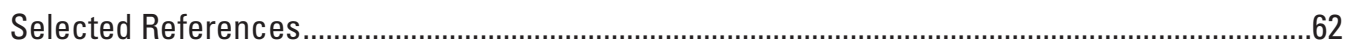

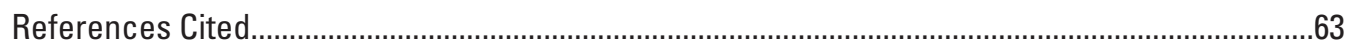

Appendix 1. Chemical Components of Plumes in Bethpage, New York .......................................64

Appendix 2. Regional Model Construction for Groundwater Flow in Central Long Island,

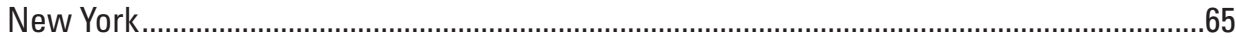

\section{Figures}

1. Model-grid domain, sections, and other local features for southeastern Nassau

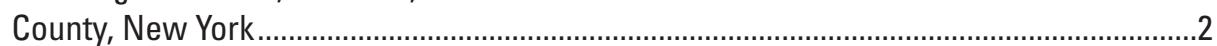

2. Model row and column sections in Nassau County, Long Island, New York .....................4

3. Conceptual diagram and cross section for hydrogeologic conditions of the border of Nassau and Suffolk Counties, New York.........................................................

4. Map showing zones used to calculate simulated water-budget terms for southeastern Nassau County, New York

5. Map showing production wells and drain cells within focus area, southeastern Nassau County, New York ............................................................................................

6. Map showing locations of selected observation wells and streamgages in southeastern Nassau County, New York ....................................................................11

7. Graph showing water-level elevations in well N12250 measured from 2005 to $2018 \ldots . . . .14$

8. Graph showing water-level elevation in well N180 measured from 2005 to 2018............14

9. Graph showing daily mean discharge at U.S. Geological Survey streamgage 01309500, Massapequa Creek at Massapequa, New York, from 2005 to 2015 
10. Graph showing daily mean discharge at U.S. Geological Survey streamgage 0309950, Bellmore Creek at Bellmore, New York, from 2005 to 2015.

11. Graph showing the relation between observed and simulated hydraulic heads calculated for present steady-state conditions by a groundwater-flow model, southeastern Nassau County, New York.

12. Maps showing hydraulic conductivity and the volatile organic-compound plume for model layers 1 and 19 for southeastern Nassau County, New York.

13. Map showing the water table, depth to water, and the volatile organic compound plume under present steady-state conditions in southeastern Nassau County, New York...

14. Graph showing number of model cells per layer that intersect the total chlorinated volatile organic compound plumes in southeastern Nassau County, New York

15. Map showing stress locations for remedial well pumping under present conditions and scenario 1 in southeastern Nassau County, New York

16. Map showing the volatile organic compounds plume shell and scenario 1 particle pathlines started at the plume shell, southeastern Nassau County, New York

17. Map showing scenario 1 locations of treated-water return and simulated water-table change from present conditions, southeastern Nassau County, New York.

18. Maps showing remedial pumping wells for layers 6 through 15 of a model for the volatile organic compounds plume shell scenarios $2 \mathrm{~A}$ and $2 \mathrm{~B}$, southeastern Nassau County, New York

19. Maps showing locations of treated water return and simulated water-table change in scenarios $2 \mathrm{~A}$ and 2B, southeastern Nassau County, New York.

20. Maps showing scenarios $3 \mathrm{~A}$ and $3 \mathrm{~B}$ and particle pathlines started the plume shell, southeastern Nassau County, New York.

21. Maps showing locations in scenarios $3 \mathrm{~A}$ and $3 \mathrm{~B}$ of treated-water return and simulated water-table change from scenario 1, southeastern Nassau County, New York

22. Map showing scenario 4 pumping wells, the plume shell, and particle pathlines starting at the plume shell, southeastern Nassau County, New York.

23. Map showing scenario 4 locations of treated-water return and simulated water-table change from scenario 1, southeastern Nassau County, New York.

24. Maps showing remedial wells, the volatile organic compound plume shell, and particle pathlines started at plume shell for scenarios $5 A$ and $5 B$, southeastern Nassau County, New York

25. Maps showing changes in the locations of treated-water return and the simulated water table in scenarios $5 \mathrm{~A}$ and $5 \mathrm{~B}$ from scenario 1, southeastern Nassau County, New York

26. Graphs showing effects of variation in total natural recharge on the present-conditions steady-state MODFLOW model, southeastern Nassau County, New York.

27. Graph showing effects of variation in total natural recharge on the present-conditions steady-state endpoint locations for the volatile organic compound plume in southeastern Nassau County, New York

28. Graph showing sensitivities of mean travel times in the volatile organic compound plume of scenario particles to porosity, southeastern Nassau County, New York 


\section{Tables}

1. Characteristics of hydrogeologic units, southeastern Nassau County, New York............5

2. Range of land-surface elevations within the focus area on Long Island, New York ........5

3. Average (2010-2015) production-well pumping rates and screen elevation for wells in southeastern Nassau County, New York.

4. Summary statistics for water-level elevations in selected observation wells measured monthly by the U.S. Geological Survey from 2005 to 2015 in southeastern Nassau County, New York

5. Water-level elevations in selected observation wells measured by the Naval Facilities Engineering Command from 2015 to 2018 in southeastern Nassau County, New York

6. Initial and final calibrated parameter values of present steady-state conditions used in the groundwater-flow model for southeastern Nassau County, New York ........16

7. Observed minus simulated water-level values for residuals of a groundwater-flow model based on calibrated current steady-state conditions for southeastern Nassau County, New York

8. Observed minus simulated streamflow residuals of calibrated present steady-state conditions calculated by a groundwater-flow model, southeastern Nassau County, New York.

9. Water budget under present steady-state conditions simulated by the groundwater-flow model, southeastern Nassau County, New York.

10. Characteristics of scenarios calculated by a simulation of present conditions and eight remedial scenarios, southeastern Nassau County, New York.

11. Statistics of particle travel time to discharge for the present-conditions simulation and eight remedial scenarios, southeastern Nassau County, New York.......27

12. Simulated water levels and streamflows under present conditions and remedial scenarios, southeastern Nassau County, New York

13. Simulated steady-state-zone budget terms of focus-area model under present conditions and remedial scenarios, New York

14. Well-pumping rates in southeastern Nassau County, New York, under scenario 1 .......31

15. Well-pumping rates in southeastern Nassau County, New York, under scenario 2 .......35

16. Well-pumping rates in southeastern Nassau County, New York, under scenarios $3 \mathrm{~A}$ and $3 \mathrm{~B}$

17. Well-pumping rates in southeastern Nassau County, New York, under scenario 4 .......46

18. Well-pumping rates in southeastern Nassau County, New York, under scenario 5 .......49 


\section{Conversion Factors}

U.S. customary units to International System of Units

\begin{tabular}{|c|c|c|}
\hline Multiply & By & To obtain \\
\hline \multicolumn{3}{|c|}{ Length } \\
\hline foot $(\mathrm{ft})$ & 0.3048 & meter $(\mathrm{m})$ \\
\hline mile (mi) & 1.609 & kilometer (km) \\
\hline \multicolumn{3}{|c|}{ Volume } \\
\hline gallon (gal) & 3.785 & liter (L) \\
\hline \multicolumn{3}{|c|}{ Flow rate } \\
\hline cubic foot per second $\left(\mathrm{ft}^{-} / \mathrm{s}\right)$ & 0.02832 & cubic meter per second $\left(\mathrm{m}^{3} / \mathrm{s}\right)$ \\
\hline gallon per minute (gal/min) & 0.06309 & liter per second $(\mathrm{L} / \mathrm{s})$ \\
\hline \multicolumn{3}{|c|}{ Hydraulic conductivity } \\
\hline foot per day (ft/d) & 0.3048 & meter per day $(\mathrm{m} / \mathrm{d})$ \\
\hline
\end{tabular}

\section{Datum}

Vertical coordinate information is referenced to the North American Vertical Datum of 1988 (NAVD 88), referred to in this report as "sea level."

Horizontal coordinate information is referenced to the North American Datum of 1983 (NAD 83).

Elevation, as used in this report, refers to distance above the vertical datum.

\section{Supplemental Information}

Concentrations of chemical constituents in water are given in parts per billion (ppb).

\section{Abbreviations}

Kh horizontal hydraulic conductivity

Kv vertical hydraulic conductivity

low-k hydraulic conductivity parameter applied in areas of low conductivity

high-k hydraulic conductivity parameter applied in areas of high conductivity

NAVFAC Naval Facilities Engineering Command

NCDH Nassau County Department of Health

NYSDEC New York State Department of Environmental Conservation

SCG standards, criteria, and guidance

SWB soil-water balance

TCE trichloroethylene

TCVOC total chlorinated volatile organic compound

USGS U.S. Geological Survey

VOC volatile organic compound 


\title{
Analysis of Remedial Scenarios Affecting Plume Movement Through a Sole-Source Aquifer System, Southeastern Nassau County, New York
}

\author{
By Paul E. Misut,1 Donald Walter,1 Christopher Schubert,1 and Sarken Dressler²
}

\section{Abstract}

A steady-state three-dimensional groundwater-flow model based on present conditions is coupled with the particle-tracking program MODPATH to assess the fate and transport of volatile organic-compound plumes within the Magothy and upper glacial aquifers in southeastern Nassau County, New York. Particles are forward tracked from locations within plumes defined by surfaces of equal concentration. Particles move toward ultimate well capture and discharge to the general head and drain boundaries representing natural receptors in the models. Because rates of advection within coarse-grained sediments typically exceed 0.1 foot per day, mechanisms of dispersion and diffusion were assumed to be negligible. Resulting particle pathlines are influenced by hydrogeologic framework features and the interplay of nearby hydrologic stresses. Simulated hydrologic effects include cones of depression near pumping wells and water-table mounding near points of treated water recharge; however, remedial pumping amounts are balanced by treated are water return, and net effects at distant regional boundaries, including freshwater/saltwater interfaces, are minor.

Once a steady-state model was developed and calibrated, eight hypothetical remedial scenarios were evaluated to hydraulically contain the volatile organic-compound plumes. Specifically, the remedial scenarios were optimized to achieve full containment by altering the pumping-well locations, adjusting the pumping rates, and adjusting the discharge locations and rates. Based on the results, total hypothetical extraction rates varied from about 5,462 gallons per minute during an anticipated near-future condition to about 13,340 gallons per minute during full hydraulic containment of all site-related compounds identified by the New York State standards, criteria, and guidance for environmental investigations and cleanup. Targeting of high-concentration zones of the plume increases the total amount of remedial pumpage necessary to capture all parts of the plume but may decrease

\footnotetext{
1U.S. Geological Survey.

${ }^{2}$ New York State Department of Environmental Conservation.
}

the total amount of time necessary to operate a remedial system. Simulated time frames of advective transport ranged from about 12 years to capture zones with elevated concentrations of volatile organic compounds (mean particle travel time plus the standard deviation of travel time) to more than 100 years to capture all zones.

Groundwater-flow model analysis indicates that all the optimal plume-containment scenarios would have negligible effects on streams and the saltwater-freshwater interface along the south shore of Long Island. Massapequa, Bellmore, Seaman, and Seaford Creeks are represented by using MODFLOW drain-boundary conditions. Saltwater-freshwater interfaces are represented by using MODFLOW general headboundary conditions where the Magothy aquifer discharges upward into saline groundwater across the Gardiners clay confining unit and the Lloyd aquifer discharges upward into saline groundwater across the Raritan confining unit.

\section{Introduction}

Several plumes of dissolved volatile organic compounds (VOCs), including trichloroethylene (TCE), have been identified in a sole-source aquifer in southeastern Nassau County, New York (fig. 1). These VOC-contaminant plumes extend from an industrial facility several miles southeast into an offsite area (Misut, 2014), and some contain "hotspots" where concentrations are one or more orders of magnitude greater than in the surrounding plume. Distributed-parameter models developed to simulate plume movement and effects on downgradient public-supply wells in the study area include Smolensky and Feldman (1995), Arcadis (2003), and Misut (2014 and 2018). Knowledge of groundwater-flow patterns and rates is essential for effective management of groundwater resources and for mitigation of potential adverse effects of the plumes on drinking-water supplies and ecosystems. This modeling analysis will allow the New York State Department of Environmental Conservation (NYSDEC) to evaluate pumpand-treat remedial alternatives identified in an amended record of decision (New York State Department of Environmental 


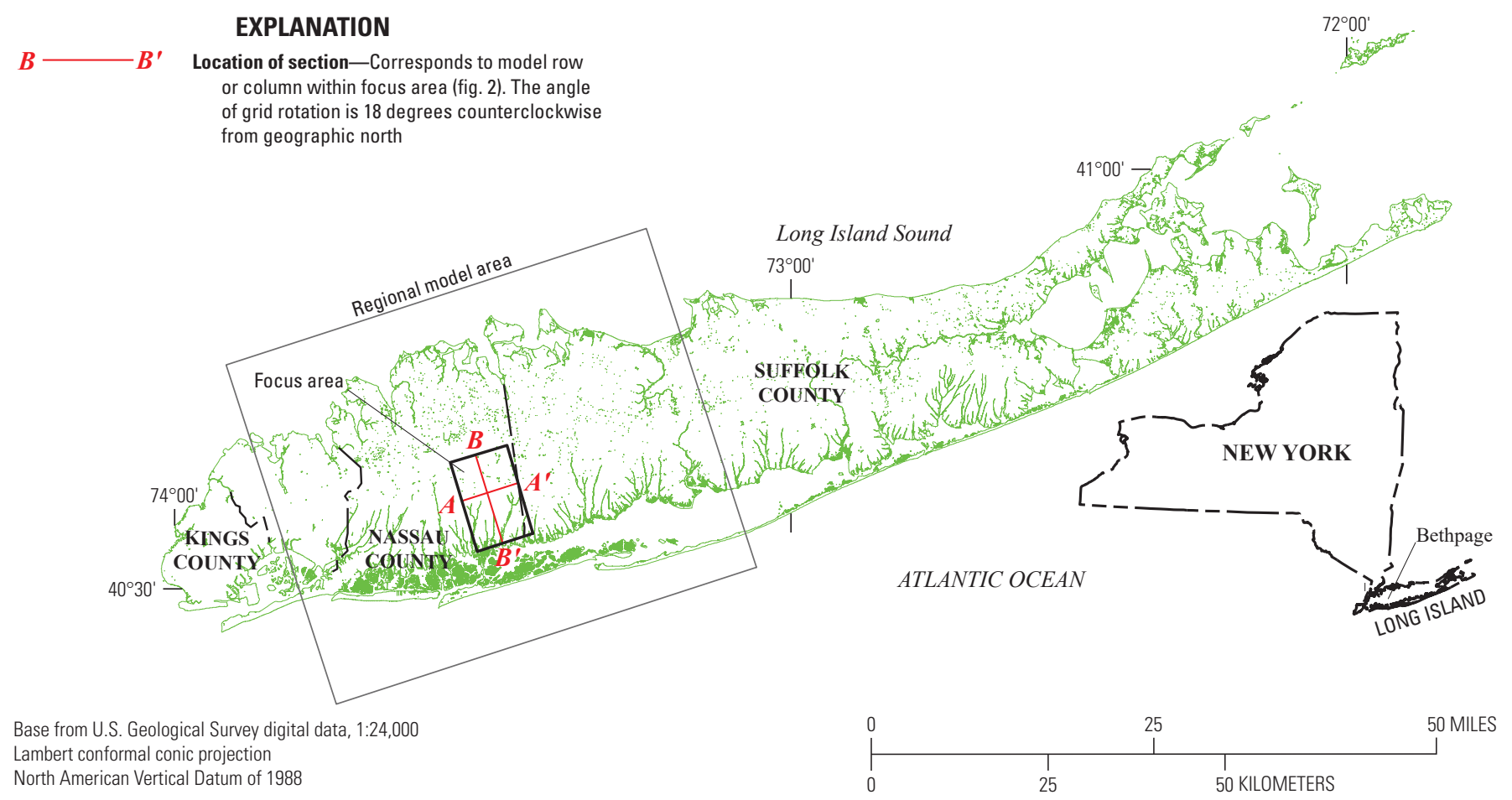

Figure 1. Model-grid domain, sections, and other local features for southeastern Nassau County, New York.

Conservation, 2019) including plume-containment and hydrologic effects. Modeling will also provide insight into the potential effect of remedial alternatives on the environment.

Modeling will provide insights regarding the optimum number, placement, depth of recovery wells, and possible options for managing treated water. These options might include the use of recharge basins, surface-water bodies, and injection wells as means for managing treated water.

\section{Purpose and Scope}

This report presents the results of a study undertaken to determine the movement of a plume within a focus area (fig. 1) of a Long Island regional-model grid. The study evaluated advective groundwater-flow patterns through hypothetical groundwater-flow simulation and particle-tracking analysis in forward mode. The groundwater-flow simulation and particletracking analysis had the following general objectives:

- develop and optimize remedial scenario alternatives to capture plumes by adjusting the number of pumping wells, locations of pumping wells and their depths of screened intervals, and pumping rates;

- evaluate the optimal locations and methods for posttreatment groundwater disposal; and

- assess the potential effects of remedial alternative scenarios to the environment (streamflows, wetlands, public water-supply wells, and saltwater intrusion).
Plumes are defined in three ways: (1) as zones where concentration of total chlorinated volatile organic compounds (TCVOCs; table 1.1) exceeds 50 parts per billion (ppb), (2) as zones where concentration of TCVOCs exceeds $100 \mathrm{ppb}$, and (3) as the extent of additional compounds whose concentrations exceeds the maximum contaminant level as stated by NYSDEC standards, criteria, and guidance (SCGs; HDR, 2019). In addition to the TCVOC compounds, other contaminants of concern exceed SCGs (table 1.1). The limit for contaminant of concern 1-4 dioxane, for example, was $0.35 \mathrm{ppb}$.

A regional groundwater-flow model was developed with variable discretization focusing on the southeastern part of Nassau County (fig. 1). A discussion of the limitations of this approach is included. Representation of plume-source loading mechanisms, such as contaminant inflow, was beyond the scope of the study. Simulations described in this report do not characterize the historical development of any plume and represent only the steady-state conditions at the present [2019] time.

\section{Previous Investigations}

Simulation of the groundwater-flow system of Nassau County began before the advent of digital computers through the use of electric-analog models (Getzen, 1977). Smolensky and Feldman (1995) simulated groundwater-flow paths in southeastern Nassau County in cooperation with the Nassau County Department of Health (NCDH) through the use of the 
U.S. Geological Survey (USGS) codes MODFLOW (McDonald and Harbaugh, 1988) and MODPATH (Pollock, 1994a, b). At the time of the first MODFLOW analysis, groundwater flowed toward deep industrial pumping wells and away from surface-recharge basins where water captured by industrial wells was reintroduced. Use of an open-loop geothermal cooling system that included pumping wells and discharge to surface-recharge basins resulted in rearrangement and partial containment of a VOC plume, which was migrating in a generally southward direction at a rate of about 200 feet per year (ft/yr) as described by Smolensky and Feldman (1995). The analysis also indicated that some groundwater upgradient from surface-recharge basins was drawn into the deep zones of industrial-well influence, but not captured, and ultimately discharged to the far-southern model boundary in the bottom part of the Magothy aquifer, near the contact with the underlying Raritan confining unit as described by Smolensky and Feldman (1995) and in subsequent sections of this report. From 1995 to the present, consultants developed a series of MODFLOW, MODPATH, and MT3D (Zheng, 1990) models that are generally consistent with the earlier USGS work but depict greater containment of VOCs upgradient from an onsite containment system and continued southward migration of VOCs downgradient from the onsite containment system (Arcadis, 2009). The remedy must conform to promulgated standards and criteria that are directly applicable or that are relevant and appropriate. The selection of a remedy must also take guidance into consideration as appropriate to the NYSDEC SCGs.

To determine whether the contaminants identified in various media are present at levels of concern, the data from this investigation were compared to media-specific SCGs. The NYSDEC has developed SCGs for groundwater, surface water, sediments, and soil. The NYSDEC has developed SCGs for drinking water and soil-vapor intrusion (New York State Department of Environmental Conservation, undated). A timeline of the modeling efforts is given in Misut (2011); subsequent particle-tracking analyses (Misut 2014, 2018) were in general agreement with previous studies. An analysis of total hydraulic-containment alternatives began with the Naval Facilities Engineering Command (NAVFAC; Tetra Tech, 2012) and was continued by the NYSDEC (HDR, 2019).

\section{Methods}

USGS codes MODFLOW-2005 (Harbaugh, 2005), and MODPATH version 6 (Pollock, 2012) were used to simulate steady-state groundwater flow and advective transport of the plume. A soil-water balance model (Westenbroek and others, 2010) was used to estimate recharge from precipitation. Kriging was used to interpolate hydraulic-conductivity fields. UCODE_2005 (Poeter and others, 2005) was used in the estimation of model parameters. Radial-basis interpolation methods were used in the delineation of the plumes (HDR, 2019).

\section{Groundwater-Flow Model}

A regional steady-state groundwater flow model of central Long Island that simulates present-day conditions forms the basis of the numerical simulations of hypothetical scenarios investigated in this study. The model is documented according to USGS guidance regarding the use of groundwater simulation in project reports (Reilly and Harbaugh, 2004).

\section{Construction}

Initially, a regional model (domain shown in fig. 1) was constructed with a regular grid of 25 layers, 617 columns, and 614 rows of 500-foot (ft)-square cells (described in app. 2). This regional model was then discretized again in a focus area (domain shown in fig. 1) surrounding the plume. This focus area includes 25 layers, 250 columns, and 346 rows of 100 -ft-square cells. Beyond the focus area of 100 -ft-square cells are square- and rectangular-shaped cells resulting from variable spacings. Vertically, the focus-area grid covers the entire depth of unconsolidated deposits (fig. 2; table 1) with bedrock as the lower boundary. The upper boundary is the land surface with a mean elevation of $80 \mathrm{ft}$ above sea level (North American Vertical Datum of 1988 [NAVD 88]; table 2). The hydrostratigraphic-unit elevations and extents that were used to represent the tops and bottoms of each layer (fig. 2) were derived from a synthesis of the elevations and extents of the topmost layer of the hydrostratigraphic units developed by Smolensky and others (1989) with the following changes: (1) revision of the Raritan clay surface to reflect recent drilling in the Bethpage area, and (2) interpretations of Stumm (1999) along the north shore of Nassau County. In general, each of the primary regional confined aquifers and confining units is represented as a separate layer in the model.

Additional layers were added to the Magothy and upper glacial aquifers to provide a better representation of pumpingwell-screen zones and to minimize the effects of weak sinksoverrepresentation of the capture zones to pumping wells in a given layer as described in (Pollock, 2012). Where a hydrogeologic unit does not extend across a given layer, a zone with a minimum thickness of $1 \mathrm{ft}$ was created, and the hydraulic properties of the overlying unit were applied in order to make the layer continuous across the model domain - a requirement of the finite-difference solution. The top of the model (layer 1), which represents the shallow part of the upper glacial aquifer, is the land surface in onshore areas and the seabed in offshore areas. The top of layer 6 is the surface elevation of the Cretaceous Magothy aquifer. The bottom of layer 23 is the top surface of the Cretaceous Raritan confining unit. The bottoms of the intervening layers (6 through 22) were generally equal divisions of those two surfaces, such that the Magothy aquifer is represented by 19 model layers of equal thickness. The bottom of layer 24 is the surface elevation of the underlying Cretaceous Lloyd aquifer, and the bottom of layer 25 is the surface elevation of the underlying crystalline bedrock (fig. 2). 

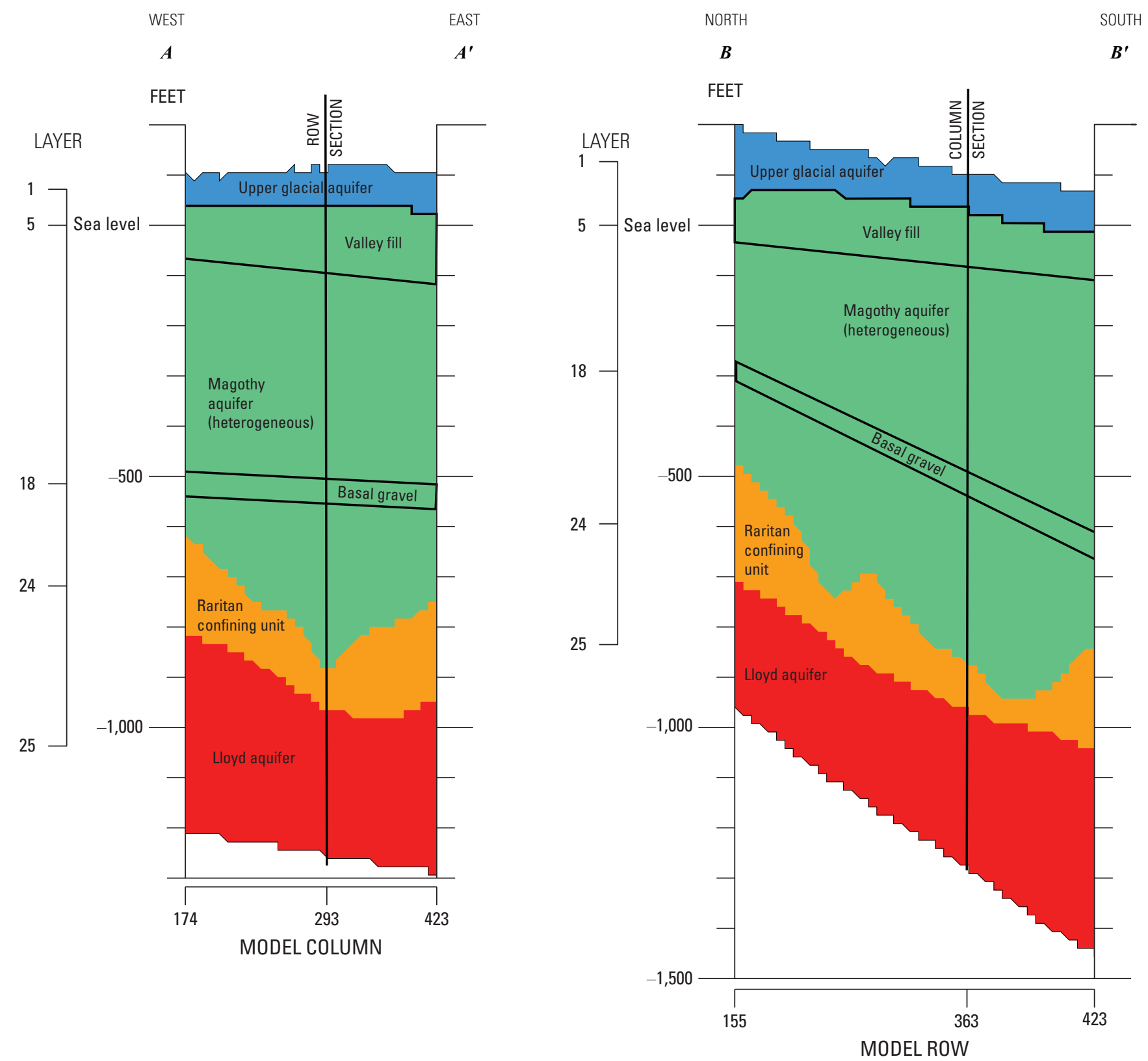

VERTICAL EXAGGERATION $\times 50$

\section{EXPLANATION}

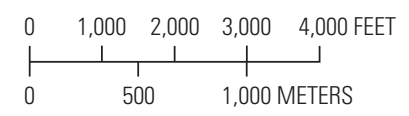

Upper glacial aquifer

Magothy aquifer

(heterogeneous)

Raritan confining unit

Lloyd aquifer

Figure 2. Model row and column sections in Nassau County, Long Island, New York. Section locations shown on figure 1. 
Table 1. Characteristics of hydrogeologic units, southeastern Nassau County, New York.

[Modified from Misut (2014) and Resolution Consultants (2017)]

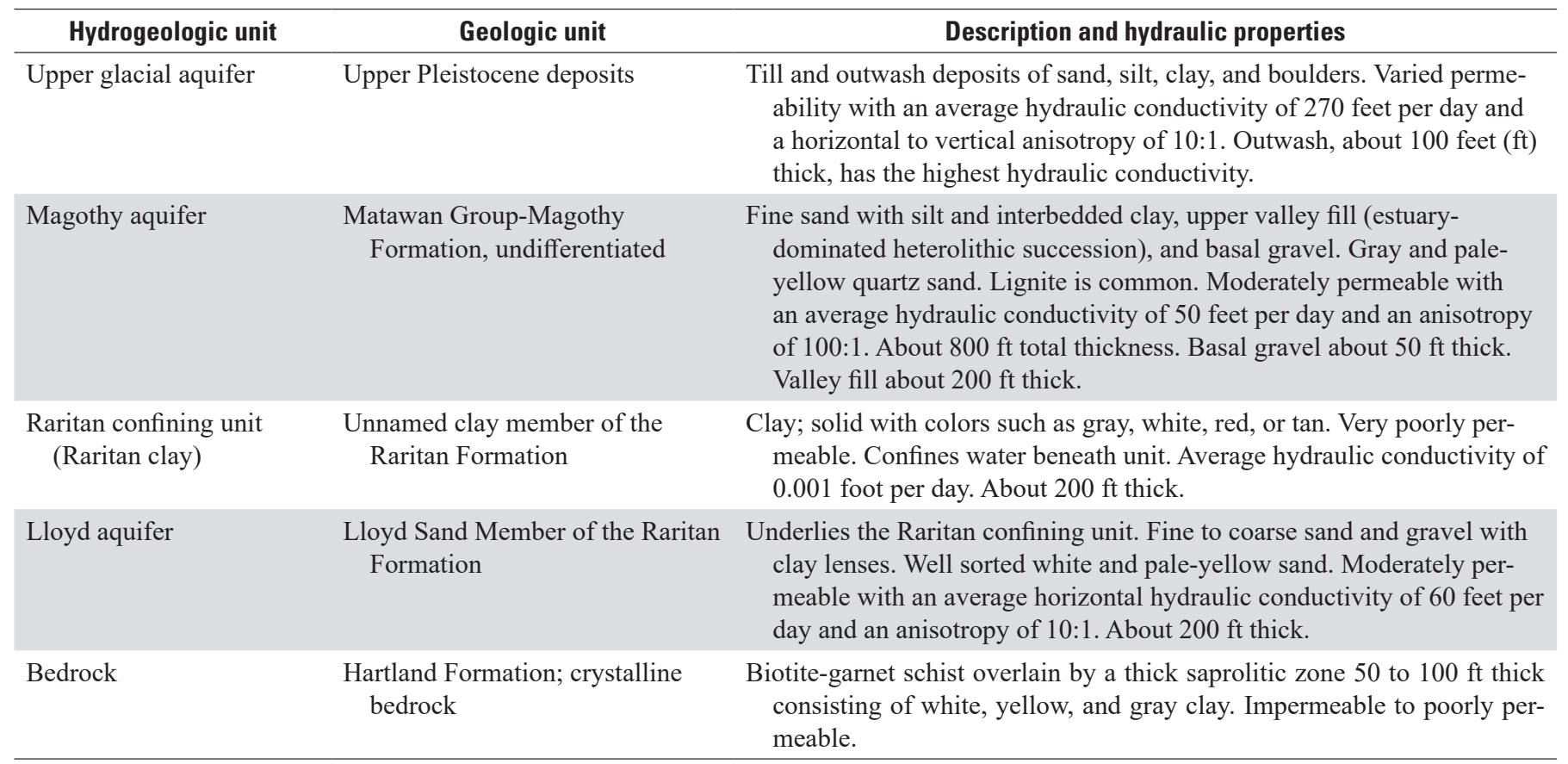

Table 2. Range of land-surface elevations within the focus area on Long Island, New York.

[Elevation values are in feet above the North American Vertical Datum of 1988]

\begin{tabular}{lc}
\hline \multicolumn{1}{c}{ Statistic } & Elevation \\
\hline Mean & 80.4 \\
Minimum & 4.1 \\
Maximum & 166.9 \\
\hline
\end{tabular}

Within the upper glacial and Magothy aquifers, a texture model (a representation of the baseline precalibrated distribution of hydraulic conductivity) based on borehole logs was used to represent heterogeneity and is described further in appendix 2 . Within other hydrostratigraphic units, hydraulicconductivity values were assigned (table 1; Smolensky and others, 1989); zones that were subject to zonal-parameter estimation are indicated in appendix 2. Within the focus area (fig. 1), additional hydraulic-conductivity parameter zones (Resolution Consultants, 2017) were classified in the Magothy aquifer to identify and represent site-specific strata having hydraulic properties that differed from the textural model. Specifically, the following zones were classified in the Magothy aquifer that otherwise were not classified in the textural model: (1) an upper Magothy valley-fill zone unit in the top 5 layers of the Magothy aquifer, and (2) a lower Magothy gravel zone in the second lowest layer in the Magothy aquifer.
Other cells within the Magothy that were not classified as within either the Magothy valley fill or Magothy gravel zones were subdivided into zones where horizontal hydraulic conductivities based on the regional textural model were either greater than or less than 100 feet per day (ft/d).

Boundary conditions along a north-south cross section are shown conceptually in figure 3 . Construction of regional model-boundary conditions are described in appendix 2. Recharge distributions and parameters include recharge through infiltration of precipitation, stormwaterrunoff mechanisms, leakage from water-supply conveyances, sewer leakage, and wastewater return flow into unsewered areas. Construction of recharge distributions is described in appendix 2. Within the focus area, additional treated water associated with the Naval Weapons Industrial Reserve Plant (NWIRP) and Northrup Grumman industrial facility (fig. 4) was returned under specified-flow boundary conditions.

Other boundary conditions are used to represent streams (MODFLOW Drain), shoreline discharge (MODFLOW General Head), and subsea discharge (MODFLOW General Head). Four streams are present within the focus area: Bellmore, Massapequa, Seaford, and Seamans Creeks. USGS streamgage stations are available for Massapequa Creek (USGS station ID 01309500) and Bellmore Creek (USGS station IDs 01309950 and 01309990; fig. 4). There is no shoreline or saltwater interface in the focus area; however, the shoreline of South Oyster Bay is hydrologically important. Fresh water from the Magothy and Lloyd aquifers (fig. 4), mixes with saline groundwater beneath the seafloor, and boundary heads were assumed to be hydrostatic with sea 


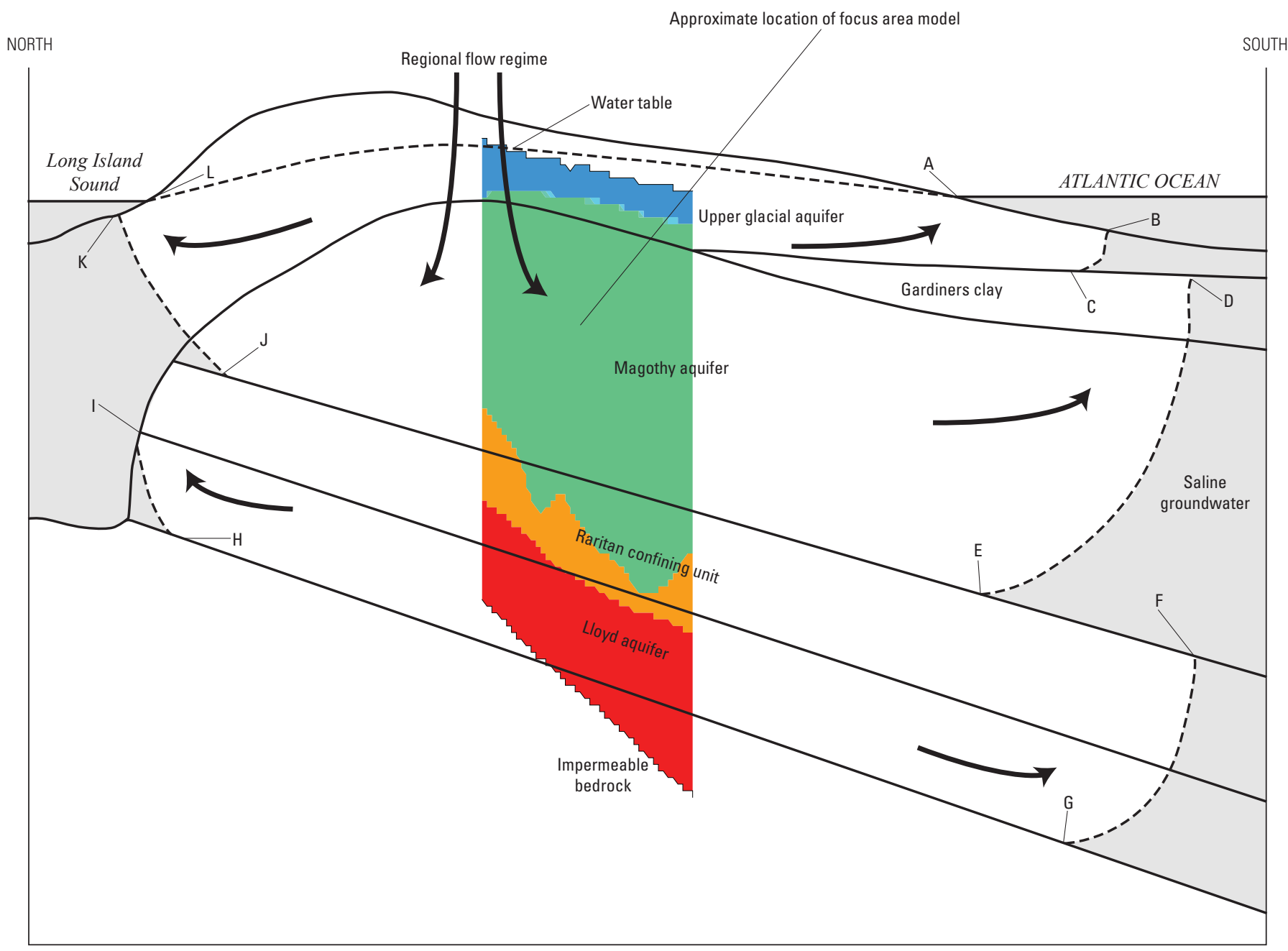

NOT TO SCALE

\section{EXPLANATION}

Model layer

Upper glacial aquifer

Magothy aquifer (heterogeneous)

Raritan confining unit

Lloyd aquifer

Saline water

Hydrogrologic unit contact-Boundary segments are as follows:

LA Water table and streams-Specified flow and head-dependent flow

HG Consolidated bedrock-No flow

$A B, K L$ Shore discharge - Constant head

$\mathrm{BC}, \mathrm{DE}, \mathrm{FG}, \mathrm{HI}, \mathrm{JK}$ Saltwater/freshwater interface-No flow; dashed

$C D$, EF, IJ Subsea discharge-Specified head

Generalized regional flow regime

Figure 3. Conceptual diagram and cross section comparing the hydrogeologic conditions of the border of Nassau and Suffolk Counties, New York, with the hydrogeologic framework for southeastern Nassau County, including the regional flow model. Conceptual diagram modified from Buxton and Smolensky (1999). 


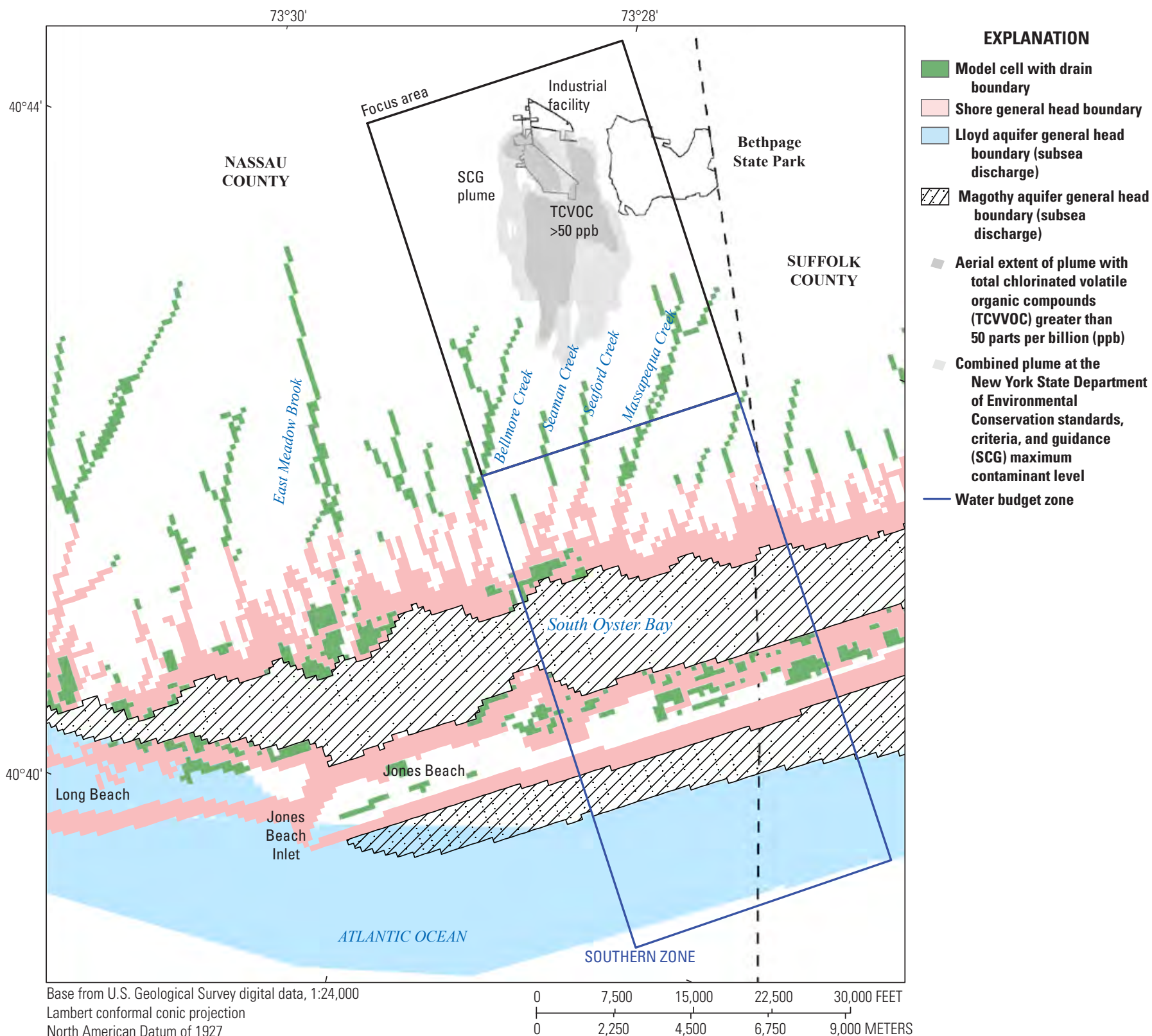

Figure 4. Map showing zones used to calculate simulated water-budget terms, representation of boundary conditions, plumes of both New York State Department of Environmental Conservation (NYSEDC) standards, criteria, and guidance (SCG) levels and total chlorinated volatile organic compounds (TCVOCs), the area in which concentrations of TCVOCs are greater than (>) 50 parts per billion (ppb; HDR, 2019), and other local features in southeastern Nassau County, New York.

level. Freshwater/saltwater interface locations are based on regional chloride distributions in the local aquifer system (Charles, 2016). To estimate movement of the freshwater/ saltwater interface downgradient of the southeastern Nassau County plume, an outer water-budget zone was established for tabulation of discharges to the various boundary conditions (fig. 4). The MODFLOW Zonebudget utility was used for this purpose (Harbaugh, 2005).

Production wells outside of the focus area of the model are at regional model-cell centroids, whereas production wells inside of the focus area are located at their precise geographic locations (fig. 5; table 3). Average pumping rates from 2010 to 2015 for all production wells were simulated in the steadystate model.

\section{Calibration}

Hydraulic conductivity and boundary-condition parameters were adjusted through automated and manual methods based on matching water-level and streamflow data. The automated calibration software UCODE_2005 (Poeter and 


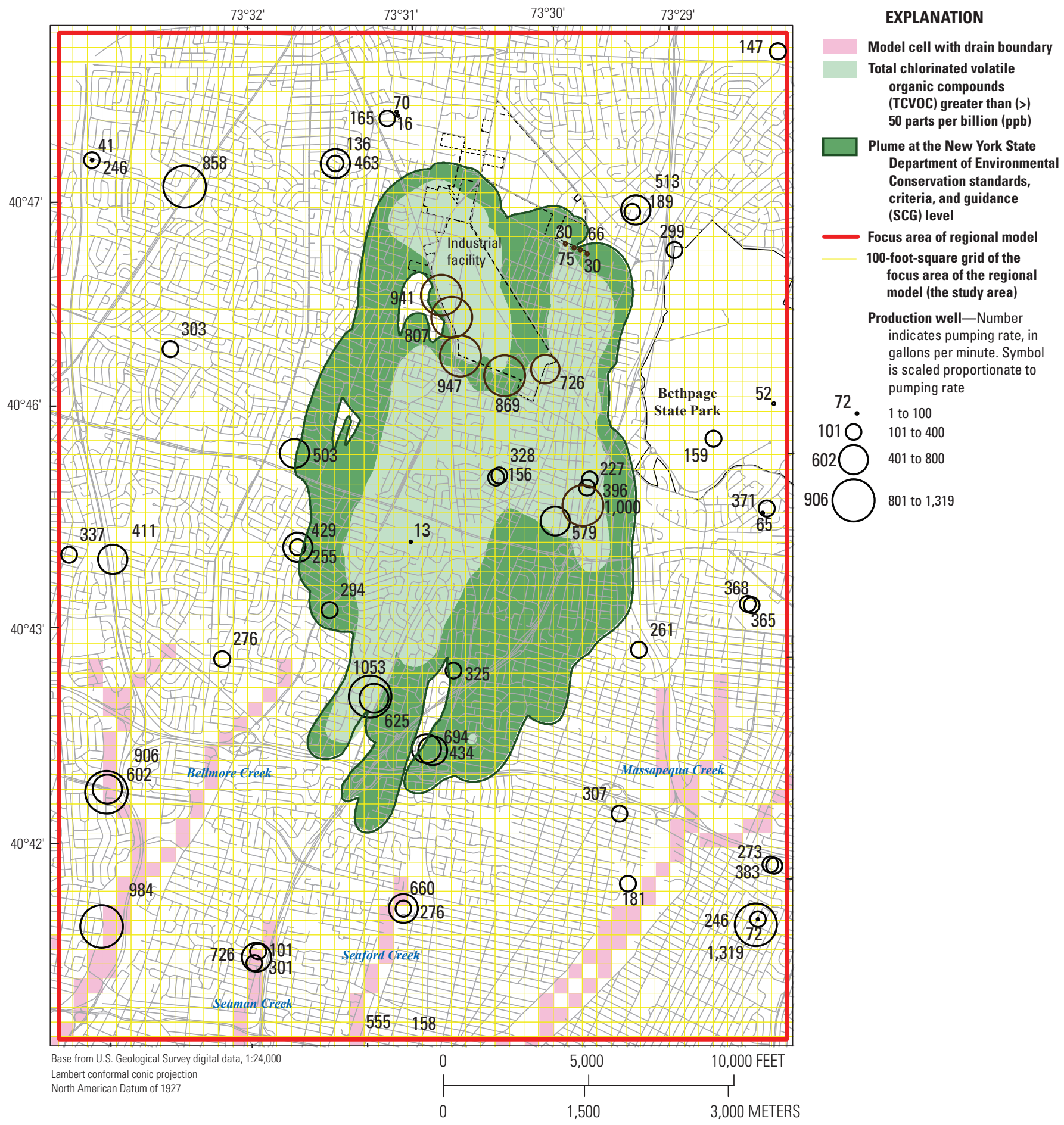

Figure 5. Map showing production wells and drain cells within focus area; plumes at New York State Department of Environmental Conservation (NYSEDC) standards, criteria, and guidance (SCG) levels; and plumes with concentrations of total chlorinated volatile organic compounds (TCVOC) greater than (>) 50 parts per billion (HDR, 2019), southeastern Nassau County, New York. 
Table 3. Average (2010-2015) production-well pumping rates and screen elevation for wells in southeastern Nassau County, New York.

[Pumping rates are listed in gallons per minute; elevations of screen top and bottom are listed in feet above the North American Vertical Datum of 1988. NWIS, National Water Information System (U.S. Geological Survey, 2019); ID, identification number]

\begin{tabular}{|c|c|c|c|c|}
\hline NWIS ID & $\begin{array}{l}\text { Produc- } \\
\text { tion well }\end{array}$ & $\begin{array}{l}\text { Pumping } \\
\text { rate } \\
\text { (gal/min) }\end{array}$ & $\begin{array}{c}\text { Screen } \\
\text { top } \\
\text { (ft, NAVD } \\
\text { 88) }\end{array}$ & $\begin{array}{c}\text { Screen } \\
\text { bottom } \\
\text { (ft, NAVD } \\
\text { 88) }\end{array}$ \\
\hline \multicolumn{5}{|c|}{ Supply } \\
\hline 404353073291201 & N3876.1 & 156 & -236 & -294 \\
\hline 404636073280701 & N4095.1 & 147 & -285 & -335 \\
\hline 404154073261801 & N4602.1 & 181 & -351 & -413 \\
\hline 404307073274701 & N5148.2 & 261 & -228 & -299 \\
\hline 404246073314301 & N5302.1 & 411 & -365 & -418 \\
\hline 404253073300601 & N5303.1 & 294 & -404 & -456 \\
\hline 404226073304701 & N5304.2 & 276 & -356 & -408 \\
\hline 404243073315802 & N5322.1 & 337 & -401 & -441 \\
\hline 404154073261803 & N5703.1 & 246 & -346 & -421 \\
\hline 404054073294901 & N5767.1 & 301 & -273 & -352 \\
\hline 404218073273301 & N6148.2 & 307 & -410 & -509 \\
\hline 404212073262101 & N6149.1 & 273 & -542 & -597 \\
\hline 404246073290301 & N6150.2 & 325 & -484 & -546 \\
\hline 404517073310203 & N6192.2 & 463 & -446 & -497 \\
\hline 404123073285003 & N6442.1 & 276 & -494 & -582 \\
\hline 404123073285002 & N6443.1 & 660 & -160 & -238 \\
\hline 405034073353701 & N6644.1 & 65 & -83 & -130 \\
\hline 404041073283601 & N6866.1 & 555 & -543 & -603 \\
\hline 404043073283601 & N6867.1 & 158 & -391 & -469 \\
\hline 404400073283201 & N6915.1 & 227 & -466 & -516 \\
\hline 404358073283102 & N6916.2 & 396 & -476 & -526 \\
\hline 404339073304401 & N7076.1 & 503 & -479 & -584 \\
\hline 404056073261101 & N7414.1 & 382 & -353 & -505 \\
\hline 404426073274305 & N7438.3 & 159 & -360 & -429 \\
\hline 404337073271101 & N7515.1 & 365 & -226 & -284 \\
\hline 404337073271102 & N7516.1 & 368 & -432 & -521 \\
\hline 404311073302501 & N7523.1 & 255 & -512 & -608 \\
\hline 404455073324902 & N7561.1 & 41 & -347 & -434 \\
\hline 404343073284301 & N8004.1 & 579 & -594 & -655 \\
\hline 404045073311601 & N8031.1 & 984 & -366 & -487 \\
\hline 404156073262004 & N8214.2 & 72 & -567 & -648 \\
\hline 404309073302901 & N8279.1 & 429 & -313 & -390 \\
\hline 404401073315103 & N8321.1 & 303 & -476 & -576 \\
\hline 404228073293301 & N8480.1 & 625 & -498 & -596 \\
\hline 404455073320301 & N8526.1 & 858 & -400 & -481 \\
\hline 404056073261102 & N8603.1 & 554 & -782 & -873 \\
\hline 404221073254501 & N8664.1 & 434 & -451 & -521 \\
\hline 404221073254502 & N8665.1 & 694 & -481 & -558 \\
\hline
\end{tabular}

Table 3. Average (2010-2015) production-well pumping rates and screen elevation for wells in southeastern Nassau County, New York.-Continued

[Pumping rates are listed in gallons per minute; elevations of screen top and bottom are listed in feet above the North American Vertical Datum of 1988. NWIS, National Water Information System (U.S. Geological Survey, 2019); ID, identification number]

\begin{tabular}{|c|c|c|c|c|}
\hline NWIS ID & $\begin{array}{l}\text { Production } \\
\text { well }\end{array}$ & $\begin{array}{l}\text { Pumping } \\
\text { rate } \\
\text { (gal/min) }\end{array}$ & $\begin{array}{l}\text { Screen } \\
\text { top } \\
\text { (ft, NAVD } \\
\text { 88) }\end{array}$ & $\begin{array}{c}\text { Screen } \\
\text { bottom } \\
\text { (ft, NAVD } \\
\text { 88) }\end{array}$ \\
\hline \multicolumn{5}{|c|}{ Supply-Continued } \\
\hline 404532073284801 & N8767.1 & 189 & -451 & -512 \\
\hline 404533073284802 & N8768.1 & 513 & -478 & -551 \\
\hline 404537073304601 & N8778.1 & 70 & -386 & -447 \\
\hline 404537073304602 & N8779.1 & 16 & -384 & -445 \\
\hline 404052073294801 & N8837.1 & 101 & -585 & -652 \\
\hline 404353073291005 & N8941.2 & 328 & -608 & -678 \\
\hline 404154073262004 & N9173.2 & 1,319 & -726 & -808 \\
\hline 404517073310205 & N9180.2 & 136 & -416 & -501 \\
\hline 404453073324605 & N9212.2 & 246 & -422 & -488 \\
\hline 404228073293507 & N9338.1 & 1,053 & -531 & -592 \\
\hline 404131073311401 & N9514.1 & 602 & -531 & -622 \\
\hline 404524073282602 & N9591.2 & 299 & -473 & -559 \\
\hline 404052073294802 & N9910.1 & 726 & -664 & -743 \\
\hline 404130073311402 & N10195.1 & 906 & -478 & -546 \\
\hline 404537073304603 & N10208.1 & 165 & -433 & -510 \\
\hline 404445073272301 & N10457.1 & 52 & -133 & -194 \\
\hline 404609073301001 & N10555.1 & 342 & -200 & -300 \\
\hline 404056073261103 & N10863.1 & 317 & -571 & -652 \\
\hline 404410073271201 & N11004.1 & 371 & -159 & -246 \\
\hline 404338073304201 & N12560.1 & 683 & -200 & -300 \\
\hline 404033073284301 & N13338.1 & 264 & -546 & -625 \\
\hline 404215073262001 & N13367.1 & 383 & -535 & -595 \\
\hline 404309073274901 & N13822.1 & 354 & -200 & -300 \\
\hline \multicolumn{5}{|c|}{23,355} \\
\hline \multicolumn{5}{|c|}{ Remedial } \\
\hline 404515073291201 & OU3 RW1 & 30 & 16 & -4 \\
\hline 404514073290801 & OU3 RW2 & 66 & 40 & 20 \\
\hline 404514073290501 & OU3 RW3 & 75 & 40 & 20 \\
\hline 404514073290101 & OU3 RW4 & 30 & 11 & -9 \\
\hline 404439073295001 & OU2 RW1 & 807 & -407 & -458 \\
\hline 404445073295701 & OU2 RW3 & 941 & -311 & -421 \\
\hline 404428073294201 & OU2 RW17 & 947 & -380 & -463 \\
\hline 404426073292001 & OU2 RW18 & 869 & -362 & -466 \\
\hline 404432073290301 & OU2 RW19 & 726 & -361 & -622 \\
\hline 404352073283001 & GM38 RW1 & 1,000 & -249 & -344 \\
\hline Total & & 5,491 & & \\
\hline
\end{tabular}


others, 2005) was applied to the present steady-state MODFLOW model. Water-level observations (fig. 6; tables 4 and 5) were collected by either the USGS or NAVFAC and were chosen to represent a stable, steady-state present condition (2005 to 2015). Streamflow gages (fig. 6) were operated by the USGS, and their measured flows were used to calculate baseflow corresponding to the same steady-state present condition. Figures 7 and 8 are hydrographs of water levels observed by the USGS, and figures 9 and 10 are hydrographs of total stream discharge measured and calculated by the USGS. Stream baseflows were separated on streamflow data to estimate the groundwater-discharge component. Water-level and discharge fluctuations are discussed in Misut (2011). Two historic influences on water-level changes were a prolonged drought during the 1960s and a large-scale sewer project during the 1980s. In 2006, a period of relatively stable climate started, continuing to about 2015, after which a drier than average period began.

During automated parameter estimation, an objective function was devised as a sum of squared water-level- and stream-discharge-weighted residuals (simulated minus observed). As parameter estimates improved, the objective function was minimized, with reductions corresponding to improvements in the matches of simulated to observed. Final parameter estimates for hydraulic conductivity and other parameters were generally greater than initial values except for Raritan and Lloyd hydraulic-conductivity parameters (table 6). Initial values are based on table 1 and (Smolensky and others, 1989). In the objective function, 19 USGSmeasured water-level targets (table 7) were weighted 2.5 times greater than 29 NAVFAC-measured water-level targets due to better temporal representation in the USGS measurements and to balance the more sparsely and regionally distributed USGS measurements with the greater density of NAVFAC measurements within the plumes. Four stream discharge targets (table 8) were weighted with a coefficient of variation approach such that they ultimately contributed about 20 percent of the total value of the objective function. Discharge targets correspond to baseflows of the 2005 to 2015 steadystate present condition.

Parameter starting values and corresponding spatial distributions are described in appendix 2. Parameters are generally of the multiplier type (Winston, 2009) with initial values set to 1 . Parameters are allowed to vary within the ranges given in table 6 . Some hydraulic properties are not spatially distributed and treated as parameters multiplying a scalar. For example, the final focus-area value of horizontal hydraulic conductivity of the Lloyd aquifer is the product of a regional uniform value of $30 \mathrm{ft} / \mathrm{d}$ (a typical value for this unit) and a parameter estimated to be 0.7 , resulting in $21 \mathrm{ft} / \mathrm{d}$. Conductance parameters are specific to the study model and were not multiplied by regional model values.

In addition to minimizing an objective function, parameter estimates should also result in residuals that approach a mean value of zero and are not biased. Residuals should spread evenly around a line of parity between simulated and observed heads (fig. 11). The NAVFAC-measured water levels are clustered near the middle of the line of parity because of their spatial density near the center of the focus area.

Resulting spatial distributions of final estimated parameters include hydraulic property- and boundary-condition values. Total recharge is the sum of five multiplier parameters and generally increases to a maximum of 44 inches per year near high-elevation areas with impervious surface including the industrial-facility and transportation corridors that enclose numerous stormwater-recharge basins. Recharge generally decreases (to a minimum of 6 inches per year) in low-lying areas with less impervious surface, including the Bethpage State Park, stream channels, and the Southern State Parkway corridor, all of which contain few stormwater-recharge basins.

Hydraulic conductivity is spatially distributed across 20 layers, including the upper glacial and Magothy aquifers (for other aquifers and confining layers, the values of hydraulic conductivity are represented by scalar). Layer examples shown on figure 12 are the water table and basal Magothy aquifer (spatial distributions for other layers are shown in Misut, 2020). During model calibration, spatial distribution is multiplied by parameters within limited zones relatively low in conductivity, including a valley-fill zone (layers 6 to 10) within the upper Magothy aquifer; a basal-gravel zone in the Magothy aquifer (layer 19), relatively high in conductivity; and an upper glacial-outwash zone that is generally higher in conductivity than upper glacial moraine and ice-contact zones. Within the upper glacial aquifer in the focus area, only the outwash zone is present, with moraine and ice contact to the north of the focus area (app. 2).

Hydraulic heads simulated by the calibrated present steady-state-conditions model are generally between 10 and $80 \mathrm{ft}$ above the North American Vertical Datum of 1988 (NAVD 88). Isolated water-table mounds with simulated heads of $70 \mathrm{ft}$ above NAVD 88 (fig. 13) are at points of remedial treated-water discharge on the south and west boundaries of the Bethpage industrial site. An isolated water-table mound with a simulated head of $60 \mathrm{ft}$ above NAVD 88 (fig. 13) is about 3,000 ft to the southeast of the site near the GM38hotspot treatment system (Misut, 2014). Recharge basins that dispose of treated wastewater are explicitly represented in the model, while the effects of stormwater basins are lumped by the soil-water balance (SWB) approach in the recharge distribution at the regional model scale. Cones of depression form at pumping wells (fig. 5). Hydraulic heads are also generally lower near stream-discharge boundaries, where stream channels incise the water table (fig. 13). Dry stream channels may extend upgradient from stream headwaters but do not result in simulated head depressions. Along the northeast boundary of the focus area are hills, and the depth to water is generally greater than in the outwash plain to the west and south. The Bethpage State Park is in a hilly moraine area with a relatively thick unsaturated zone.

Vertical hydraulic-head gradients generally trend downward (positive gradient) in the northern part of the focus area and upward (negative gradient) in the southern part of 


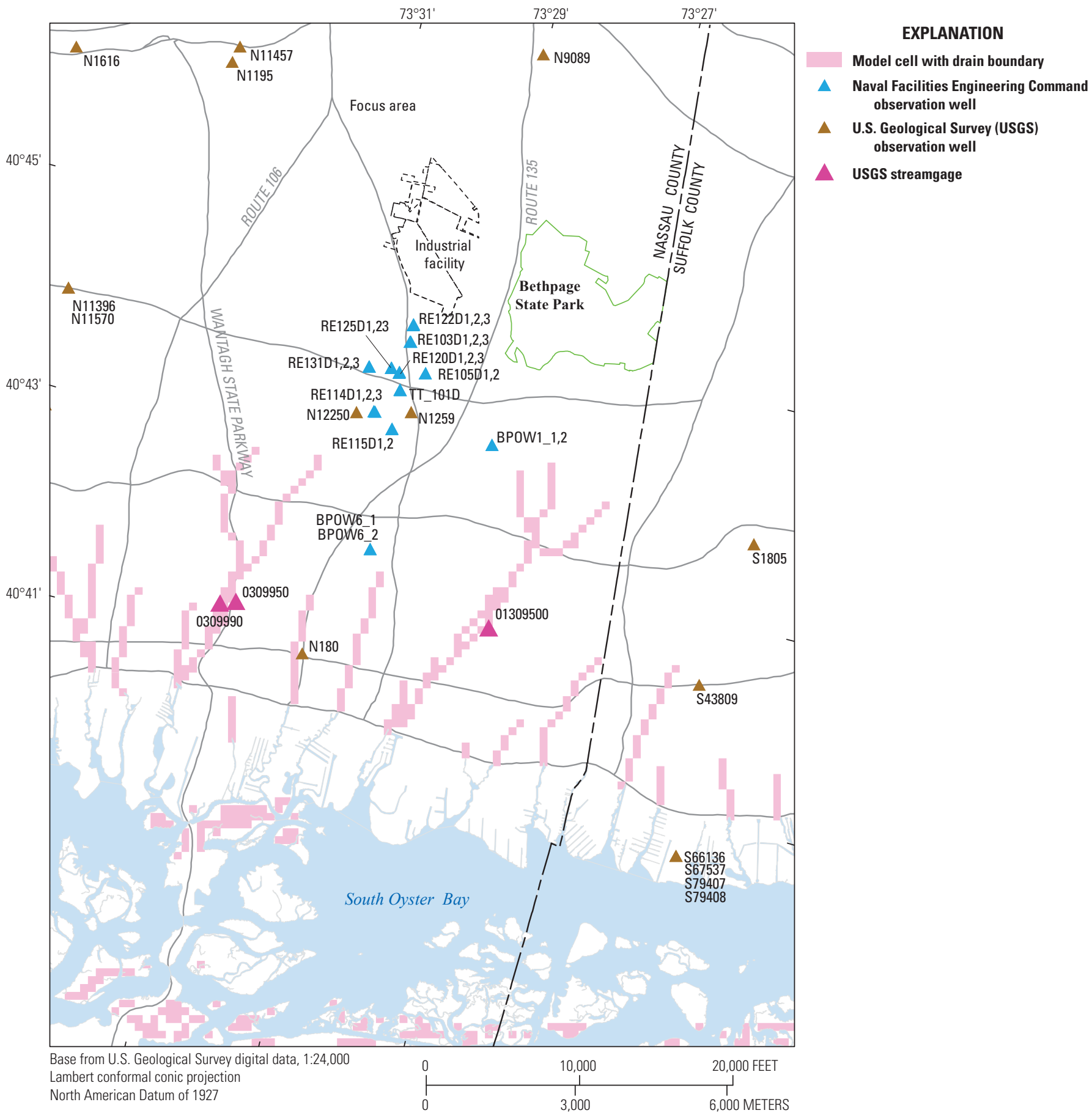

Figure 6. Map showing locations of selected observation wells and streamgages in southeastern Nassau County, New York.

the focus area, in accordance with the regional-flow regime (fig. 3). Active areas of downflow across the valley-fill zone within the Magothy aquifer, however, occur at points of treated-water discharge to the water table above the valley fill (fig. 4), and at points of water withdrawal from wells below the valley fill. In addition, there is an active area of upflow near a series of shallow remedial wells above the valley fill in an eastern section of the Bethpage industrial area (fig. 5). Vertical hydraulic-head gradients across the top of the basal gravel zone within the Magothy aquifer generally trend downward (positive gradient) in the northern part of the focus area and upward (negative gradient) in the southern part of the focus area, in accordance with the regional-flow regime (fig. 3). Active areas of upward and downward flow are influenced by local well stresses (fig. 5) that may be above or below the active area. Misut (2020) provides illustrations of simulated vertical head gradients and head contours in selected model layers. 
Table 4. Summary statistics for water-level elevations in selected observation wells measured monthly by the U.S. Geological Survey from 2005 to 2015 in southeastern Nassau County, New York.

[Elevations are in feet above the North American Vertical Datum of 1988. NWIS, National Water Information System (U.S. Geological Survey, 2019); ID, identification number]

\begin{tabular}{rlrrrrrl}
\hline NWIS ID & Well ID & Top & Bottom & $\begin{array}{c}\text { Mean } \\
\text { head }\end{array}$ & $\begin{array}{c}\text { Median } \\
\text { head }\end{array}$ & $\begin{array}{c}\text { Standard } \\
\text { deviation }\end{array}$ & Aquifer \\
\hline 405600072150002 & $\mathrm{~S} 67537.1$ & -50 & -55 & 0.83 & 0.89 & 0.43 & Upper glacial \\
405504073011201 & $\mathrm{~S} 66136.1$ & -118 & -128 & 2.99 & 2.96 & 0.39 & Magothy \\
403533073353202 & $\mathrm{~N} 6850.2$ & -892 & -903 & 3.99 & 4.20 & 0.90 & Magothy \\
405906072110102 & $\mathrm{~S} 79408.1$ & -663 & -668 & 5.16 & 5.25 & 0.46 & Magothy \\
403922073353501 & $\mathrm{~N} 67.1$ & -900 & -910 & 10.77 & 11.12 & 1.79 & Lloyd \\
404030073293703 & $\mathrm{~N} 180.2$ & -723 & -788 & 13.07 & 13.18 & 2.21 & Magothy \\
404326073341801 & $\mathrm{~N} 11570.1$ & -768 & -788 & 16.24 & 16.45 & 1.85 & Lloyd \\
403935073235003 & $\mathrm{~S} 79407.1$ & $-1,185$ & $-1,207$ & 17.83 & 18.02 & 0.89 & Lloyd \\
405906072110102 & $\mathrm{~S} 79408.1$ & 8 & -2 & 19.20 & 19.48 & 1.16 & Magothy \\
404622073330701 & $\mathrm{~N} 11457.1$ & -687 & -707 & 25.89 & 26.25 & 1.70 & Lloyd \\
404210073340801 & $\mathrm{~N} 1615.4$ & 31 & 28 & 38.93 & 39.02 & 1.09 & Upper glacial \\
404319073184701 & $\mathrm{~S} 1805.4$ & 26 & 24 & 39.79 & 39.88 & 1.95 & Upper glacial \\
404303073295501 & $\mathrm{~N} 12250.1$ & 17 & 22 & 45.65 & 45.53 & 1.38 & Upper glacial \\
404317073291105 & $\mathrm{~N} 1259.5$ & 40 & 37 & 47.52 & 47.50 & 1.29 & Upper glacial \\
404338073371502 & $\mathrm{~N} 10035.1$ & 29 & 24 & 51.42 & 51.50 & 1.71 & Upper glacial \\
404327073341701 & $\mathrm{~N} 11396.1$ & -477 & -497 & 51.86 & 52.04 & 1.26 & Magothy \\
404553073351201 & $\mathrm{~N} 1616.3$ & 56 & 51 & 73.30 & 73.55 & 2.38 & Upper glacial \\
404614073330504 & $\mathrm{~N} 1195.5$ & 37 & 32 & 78.73 & 79.01 & 1.75 & Magothy \\
404740073285701 & $\mathrm{~N} 9089.1$ & -1 & -6 & 81.35 & 81.54 & 1.43 & Magothy \\
\hline
\end{tabular}

Simulated water-budget input terms for the focus zone include the following: recharge (a combination of five components multiplied by five calibration parameters; table 6), point sources of treated-water input at the surface, and lateral inflows. Simulated water-budget output terms for the focus zone include the following: pumpage, discharges to Massapequa, Seamans, Seaford, and Bellmore Creeks, and lateral outflows. For model-calibration purposes, observed and simulated values of stream discharges were compared (table 8). As shown in figure 4, the focus area is embedded within a regional model, and significant amounts of water flow laterally beyond the focus area. Downgradient from the focus area, three southern water-budget zones were established to assess the effects of plume remediation on natural environmental discharges (stream, wetland, coastal, and subsea types; table 9). About 25 percent of the total outflow from the focus area enters these zones. Inside the southern zones, these waters mix with water of other origins and may ultimately discharge to environmental receptors. In the southern zones and for Long Island generally, more than 90 percent of the natural environmental discharge occurs from the upper glacial aquifer to shorelines or streams; less than 10 percent of this discharge water leaves at the subsea boundaries of the Lloyd and Magothy aquifers. In some parts of southern Nassau County, saltwater intrusion has been observed near the freshwater/ saltwater interfaces of the deep Lloyd aquifer, and the regional model simulates reverse-gradient inflow from corresponding subsea-discharge boundaries; however, this occurs mainly to the west near Long Beach (fig. 4).

\section{Delineation of Plume Zones}

Plume zones representing concentrations of 50 (fig. 5) and $100 \mathrm{ppb}$ TCVOC (compounds listed in table 1.1) were laterally and vertically delineated by consultants (HDR, 2019). Additionally, the plume of selected solutes at the SCG concentrations were delineated separately (listed in table 1.1) and then merged into a composite SCG plume (fig. 5). The SCG plume, which is about 4 miles (mi) long with a maximum depth of about $800 \mathrm{ft}$ below land surface, has been detected within the upper glacial and Magothy aquifers, whereas TCVOC concentrations of $100 \mathrm{ppb}$ or greater have been measured solely within the Magothy aquifer (fig. 14).

During simulated present steady-state conditions, total water discharged from the SCG plume is about 36,300 gallons per minute (gal/min), with 20 percent from well pumping and the remainder flowing laterally beyond the detectable outer boundary or plume boundary. About 90 percent of TCVOCs within the SCG plume is contained by 42 billion gallons of water, with the remaining 10 percent contained by an additional 90 billion gallons of water (HDR, 2019). 
Table 5. Water-level elevations in selected observation wells measured by the Naval Facilities Engineering Command from 2015 to 2018 in southeastern Nassau County, New York.

[Elevations are in feet above the North American Vertical Datum of 1988. NWIS, National Water Information System (U.S. Geological Survey, 2019); ID, identification number]

\begin{tabular}{|c|c|c|c|c|c|c|c|}
\hline NWIS ID & Well & Well top & Well bottom & May 1, 2015 & $\begin{array}{c}\text { September 7, } \\
2017\end{array}$ & December 4, 2017 & March 24, 2018 \\
\hline 404311073275901 & BPOW1_1 & -135.7 & -180.7 & 41.56 & 40.5 & 40.51 & 42.87 \\
\hline 404145073290901 & BPOW6_1 & -506.4 & -531.4 & 24.68 & 23.21 & 25.97 & 28.38 \\
\hline 404145073290902 & BPOW6_2 & -711.4 & -736.4 & 24.29 & 22.69 & 25.59 & 28.28 \\
\hline 404358073292902 & RE103D3 & -559.4 & -579.4 & 51.18 & 50.48 & 50.72 & 52.78 \\
\hline 404342073291001 & RE105D1 & -442.4 & -462.4 & 47.58 & 47.34 & 47.53 & 49.87 \\
\hline 404342073291002 & RE105D2 & -642.4 & -662.4 & 45.01 & 46.3 & 46.49 & 49.24 \\
\hline 404309073294001 & RE114D1 & -460.4 & -480.4 & 41.29 & 40.19 & 41.96 & 44.36 \\
\hline 404302073292202 & RE115D2 & -660.6 & -680.6 & 38.68 & 37.81 & 39.79 & 42.37 \\
\hline 404337073293101 & RE120D1 & -543.9 & -563.9 & 48.51 & 46.28 & 47.15 & 49.51 \\
\hline 404337073293102 & RE120D2 & -604 & -624 & 47.64 & 46.42 & 47.3 & 49.54 \\
\hline 404337073293103 & RE120D3 & -653.9 & -673.9 & 47.08 & 46.22 & 47.39 & 49.49 \\
\hline 404409073293101 & RE122D1 & -632.3 & -652.3 & 53.38 & 53.3 & 53.2 & 54.58 \\
\hline 404409073293102 & RE122D2 & -492.3 & -512.3 & 53.08 & 52.94 & 52.79 & 54.32 \\
\hline 404409073293103 & RE122D3 & -617.4 & -637.4 & 52.56 & 51.88 & 52.49 & 53.9 \\
\hline 404339073293801 & RE125D1 & -233.9 & -253.9 & 49.71 & 49.24 & 49.39 & 46.11 \\
\hline 404338073293801 & RE125D2 & -493.7 & -513.7 & 47.61 & 46.57 & 47.41 & 49.63 \\
\hline 404327073292601 & TT_101D2 & -658.1 & -678.1 & 43.94 & 43.49 & 44.54 & 46.92 \\
\hline
\end{tabular}

\section{Particle-Tracking Analysis}

MODPATH is a postprocessing particle-tracking program designed to work with MODFLOW. Particles collectively represent a travel log and show how groundwater flows. MODPATH version 6 (Pollock, 2012) was used in forward-tracking mode with particles' starting points placed within plumes, then tracked through the present steady-state groundwater-flow model. All MODPATH simulations used to generate graphics or tables within this report are included in Misut (2020). Particles are started from an even distribution throughout the body of the plume (from MODFLOW model-cell centroids within the plumes). Aspects of the particle-tracking approach that affect the fates of particles include porosity parameterization and treatment of weak sinks. The travel times of particles are correlated to porosity parameters used to convert MODFLOW water fluxes to particle velocities. Throughout the model domain, porosity is set to 25 percent. If a particle enters a weak-sink MODFLOW cell where a portion of the water discharges to a well, and a portion flows out of the cell sides, the particle is stopped and considered captured; however, remedial wells are generally pumped at rates that generate a strong sink condition with all water entering the cell discharging to the well. 


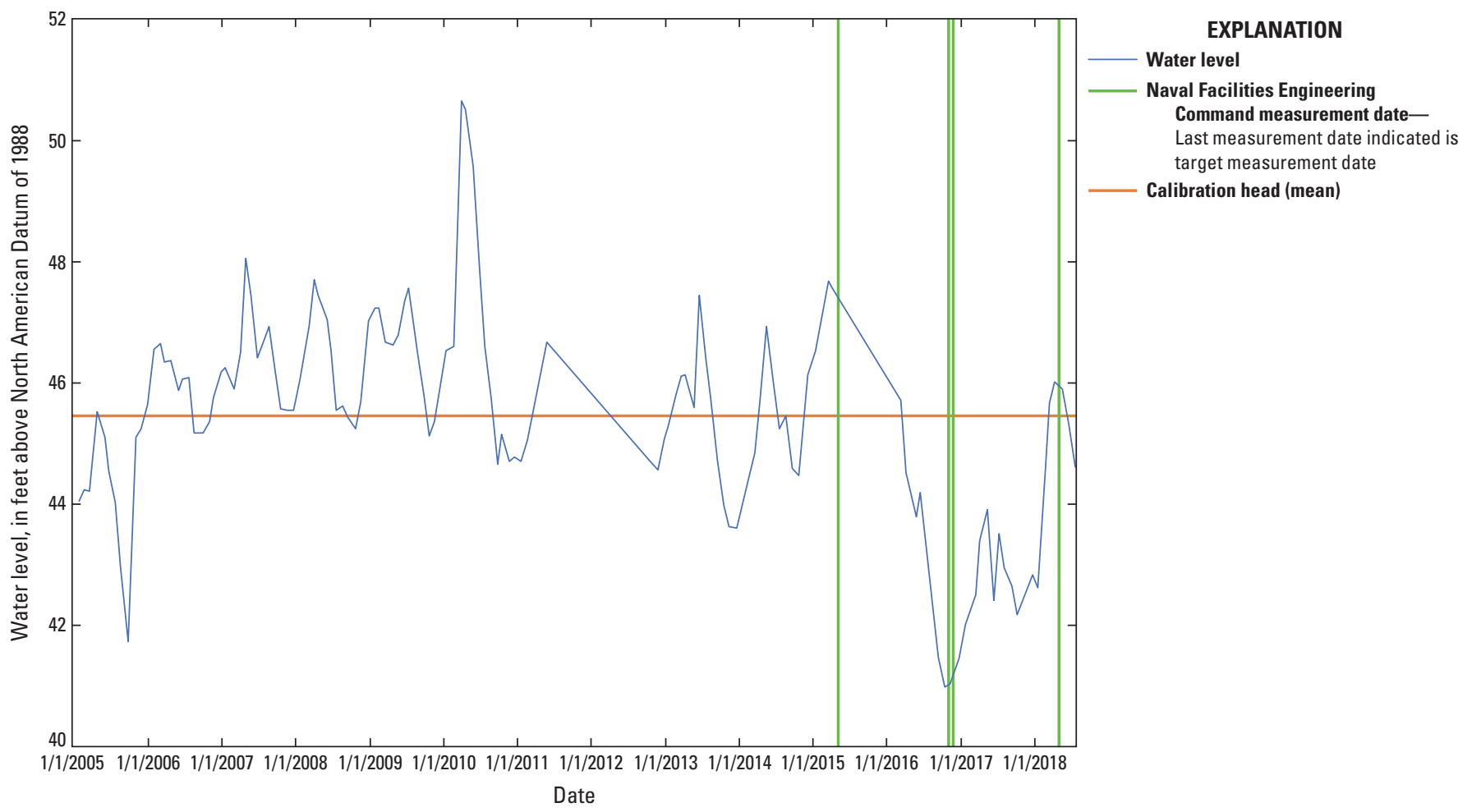

Figure 7. Graph showing water-level elevations in well N12250 measured by the U.S. Geological Survey from 2005 to 2018 , the mean water level during this period, and dates of water-level measurement by the Naval Facilities Engineering Command at nearby wells from 2015 to 2018, southeastern Nassau County, New York. Location of well shown on figure 6.

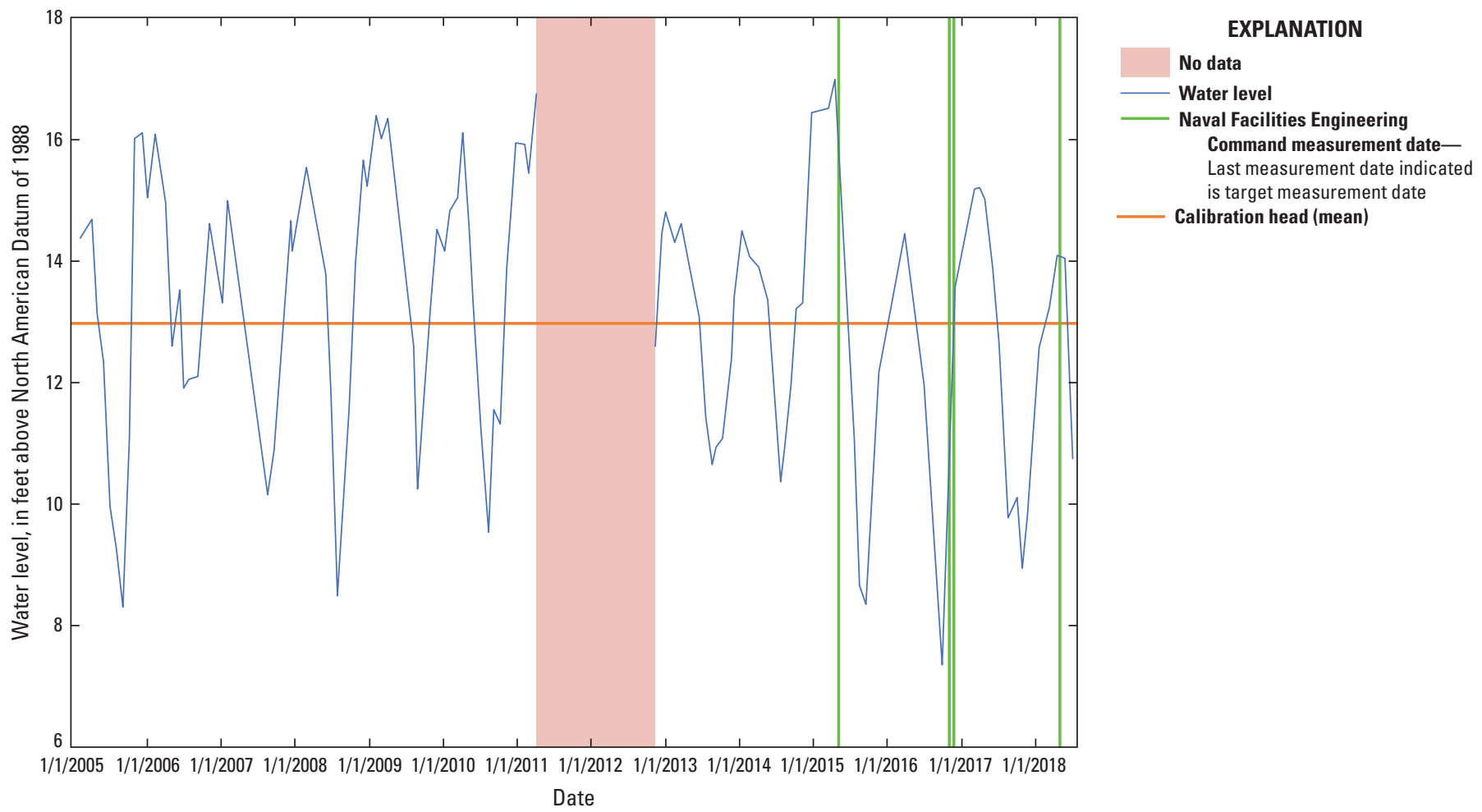

Figure 8. Graph showing water-level elevation in well N180 measured by the U.S. Geological Survey from 2005 to 2018 , the mean water level during this period, and dates of measurement by the Naval Engineering Facilities Command from 2005 to 2018, southeastern Nassau County, New York. Location of well shown on figure 6. 


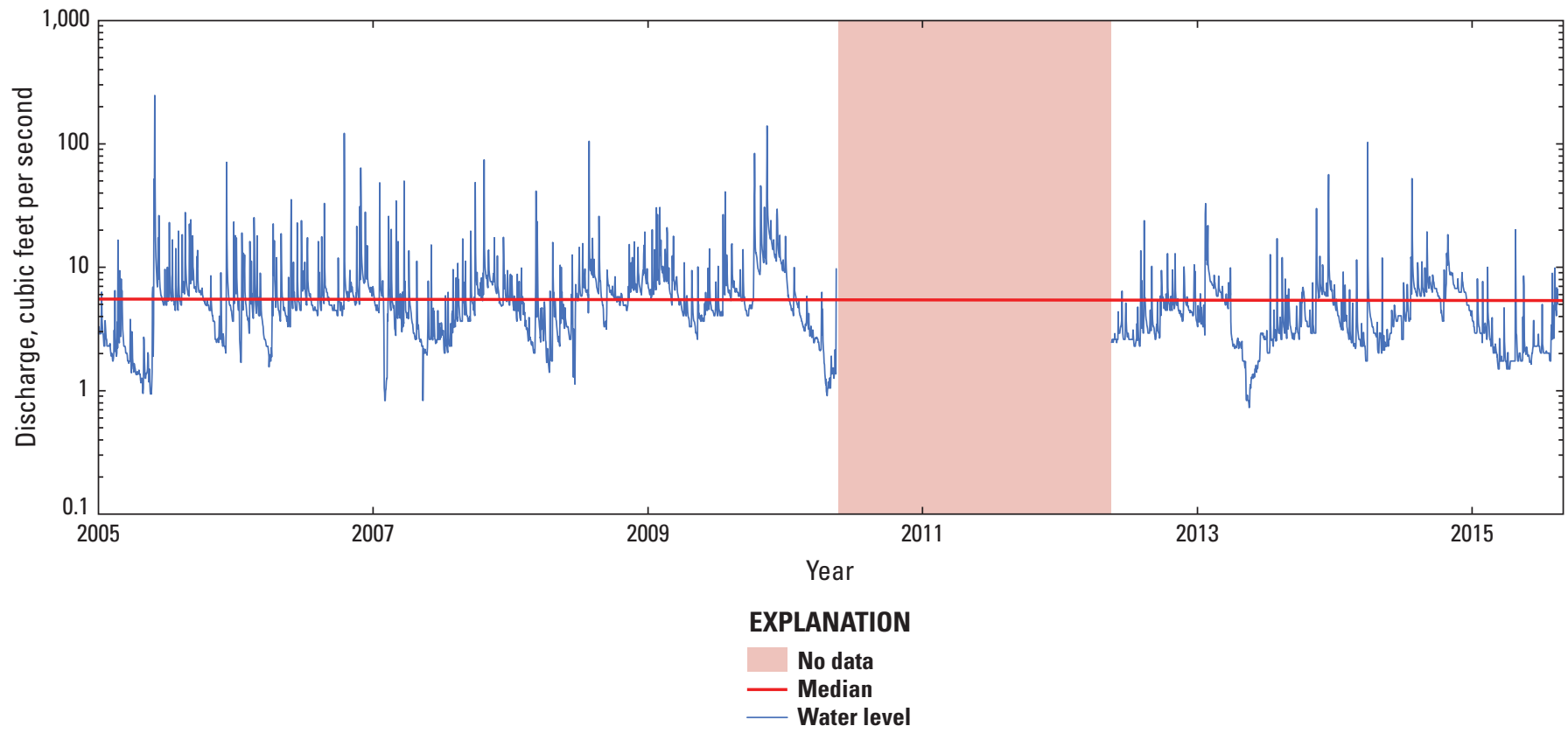

Figure 9. Graph showing daily mean discharge at U.S. Geological Survey streamgage 01309500, Massapequa Creek at Massapequa, New York, from 2005 to 2015 and the median during this period, southeastern Nassau County, New York. Location of streamgage shown on figure 6.

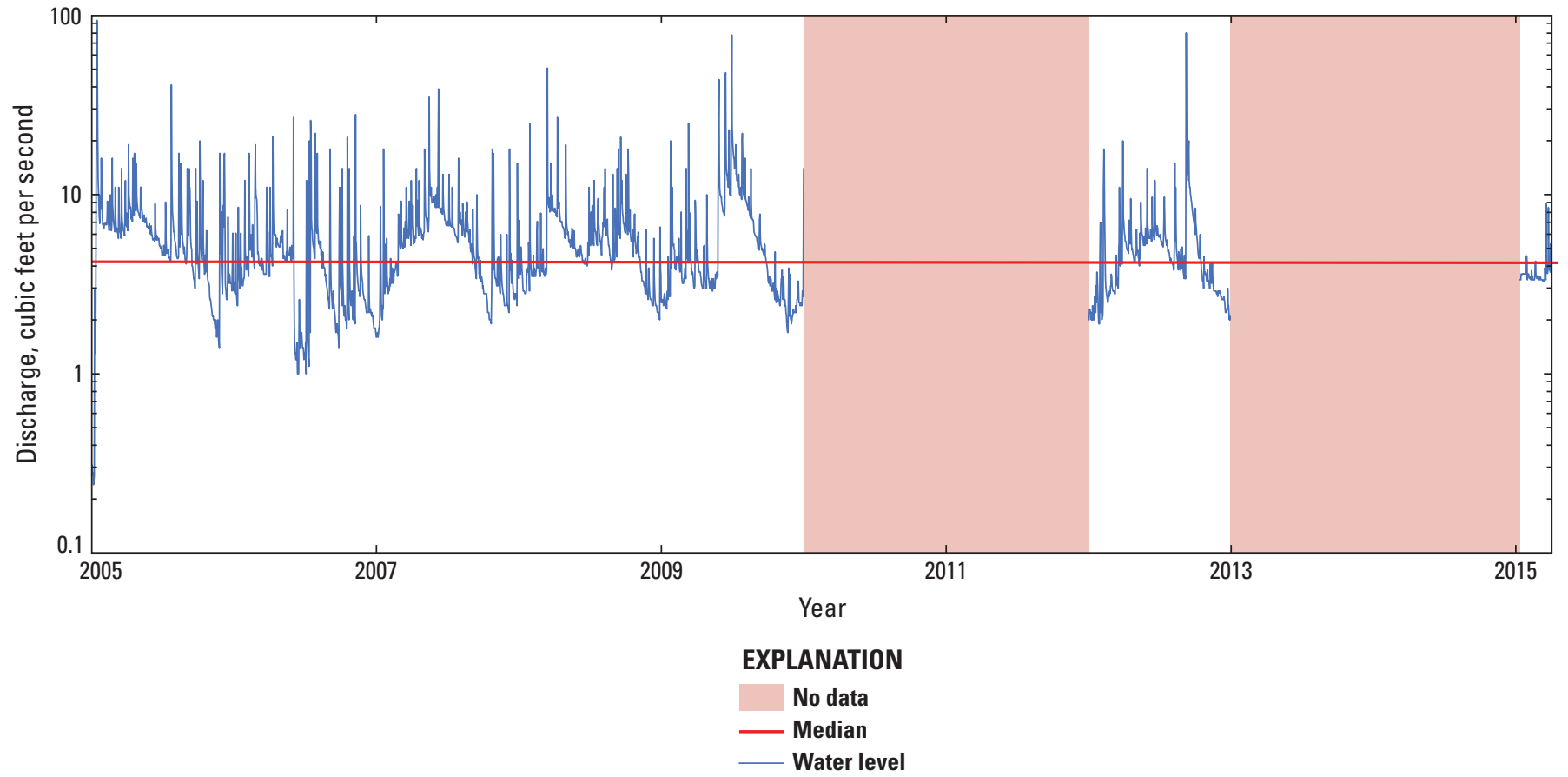

Figure 10. Graph showing daily mean discharge at U.S. Geological Survey streamgage 0309950, Bellmore Creek at Bellmore, New York, from 2005 to 2015 and the median during this period, southeastern Nassau County, New York. Location of streamgage shown on figure 6. 


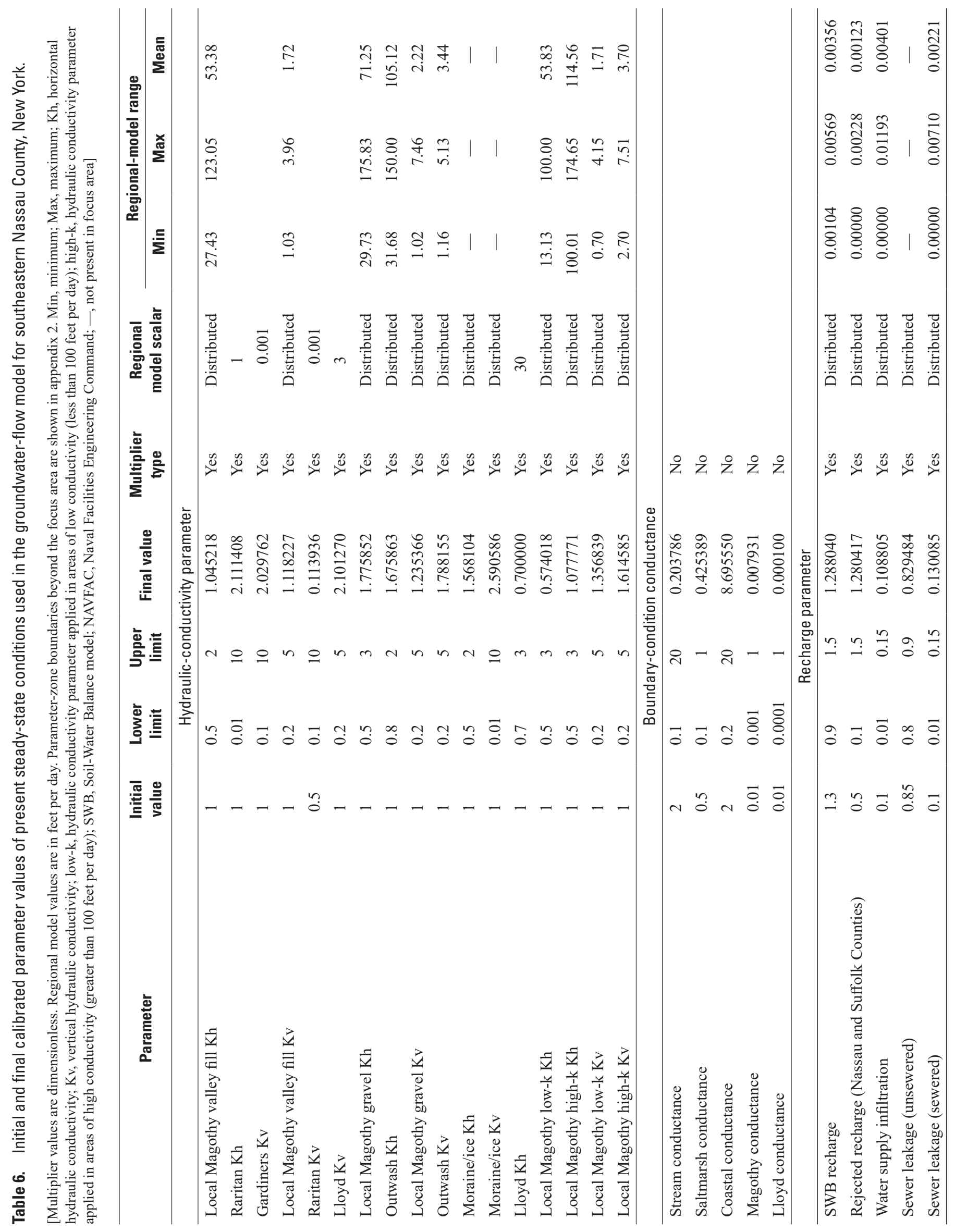


Table 7. Observed minus simulated water-level values for residuals of a groundwater-flow model based on calibrated current steady-state conditions for southeastern Nassau County, New York.

[Water levels are in feet (ft) above the North American Vertical Datum of 1988]

\begin{tabular}{|c|c|c|c|}
\hline Well & $\begin{array}{l}\text { Measured } \\
\text { value, in ft }\end{array}$ & $\begin{array}{l}\text { Simulated } \\
\text { value, in } \mathrm{ft}\end{array}$ & $\begin{array}{l}\text { Residual, } \\
\text { in ft }\end{array}$ \\
\hline \multicolumn{4}{|c|}{ U.S. Geological Survey-measured targets } \\
\hline N67 & 10.77 & 2.77 & -7.99 \\
\hline N6850 & 3.99 & 1.86 & -2.13 \\
\hline N10035 & 51.42 & 42.65 & -8.77 \\
\hline N180 & 13.07 & 11.87 & -1.2 \\
\hline N1195 & 78.73 & 74.73 & -4 \\
\hline N1259 & 47.52 & 46.51 & -1 \\
\hline N1615 & 38.93 & 36.04 & -2.89 \\
\hline N1616 & 73.3 & 66.64 & -6.66 \\
\hline N9089 & 81.35 & 83.22 & 1.87 \\
\hline S1805 & 39.79 & 41.34 & 1.55 \\
\hline S43809 & 19.2 & 21.64 & 2.44 \\
\hline S66136 & 2.99 & 7.5 & 4.51 \\
\hline S67537 & 0.83 & 3.95 & 3.11 \\
\hline S79407 & 17.83 & 18.29 & 0.46 \\
\hline S79408 & 5.16 & 7.5 & 2.33 \\
\hline N11396 & 51.86 & 50.05 & -1.81 \\
\hline N11457 & 25.89 & 15.51 & -10.38 \\
\hline N11570 & 16.24 & 8.97 & -7.27 \\
\hline N12250 & 45.65 & 45.24 & -0.41 \\
\hline N13559 & 11.81 & 2.91 & -8.9 \\
\hline Mean residual & & & 2.01 \\
\hline Root mean square error & & & 4.75 \\
\hline \multicolumn{4}{|c|}{ Naval Facilities Engineering Command -measured targets } \\
\hline BPOW1_2 & 40.28 & 43.83 & 3.55 \\
\hline BPOW1_1 & 41.48 & 43.53 & 2.05 \\
\hline BPOW6_1 & 28.38 & 27.15 & -1.23 \\
\hline BPOW6_2 & 28.28 & 26.92 & -1.36 \\
\hline
\end{tabular}

Table 7. Observed minus simulated water-level values for residuals of a groundwater-flow model based on calibrated current steady-state conditions for southeastern Nassau County, New York.-Continued

[Water levels are in feet (ft) above the North American Vertical Datum of 1988]

\begin{tabular}{|c|c|c|c|}
\hline Well & $\begin{array}{l}\text { Measured } \\
\text { value, in } \mathrm{ft}\end{array}$ & $\begin{array}{l}\text { Simulated } \\
\text { value, in } \mathrm{ft}\end{array}$ & $\begin{array}{l}\text { Residual, } \\
\text { in } \mathrm{ft}\end{array}$ \\
\hline \multicolumn{4}{|c|}{$\begin{array}{c}\text { Naval Facilities Engineering Command - } \\
\text { measured targets_-Continued }\end{array}$} \\
\hline RE103D1 & 52.92 & 54.33 & 1.41 \\
\hline RE103D2 & 52.87 & 54.3 & 1.43 \\
\hline RE103D3 & 52.78 & 54.28 & 1.5 \\
\hline RE105D1 & 49.87 & 50.94 & 1.07 \\
\hline RE105D2 & 49.24 & 50.61 & 1.37 \\
\hline RE114D1 & 44.36 & 45.13 & 0.77 \\
\hline RE114D2 & 44.35 & 44.95 & 0.6 \\
\hline RE114D3 & 44.23 & 44.82 & 0.59 \\
\hline RE115D1 & 42.3 & 42.89 & 0.59 \\
\hline RE115D2 & 42.37 & 42.71 & 0.34 \\
\hline RE120D1 & 49.51 & 50.83 & 1.32 \\
\hline RE120D2 & 49.54 & 50.73 & 1.19 \\
\hline RE120D3 & 49.49 & 50.77 & 1.28 \\
\hline RE122D1 & 54.58 & 56.49 & 1.91 \\
\hline RE122D2 & 54.32 & 56.16 & 1.84 \\
\hline RE122D3 & 53.9 & 56.03 & 2.13 \\
\hline RE125D1 & 46.11 & 51.74 & 5.63 \\
\hline RE125D2 & 49.63 & 51.34 & 1.71 \\
\hline RE125D3 & 49.68 & 51.27 & 1.59 \\
\hline RE131D1 & 49.99 & 51.11 & 1.12 \\
\hline RE131D2 & 49.31 & 51.07 & 1.76 \\
\hline RE131D3 & 49.1 & 51.11 & 2.01 \\
\hline $\mathrm{TT}_{-} 101 \mathrm{D}$ & 48.31 & 49.01 & 0.7 \\
\hline $\mathrm{TT}_{-} 101 \mathrm{D} 1$ & 47.32 & 48.73 & 1.41 \\
\hline $\mathrm{TT}_{-} 101 \mathrm{D} 2$ & 46.92 & 48.44 & 1.52 \\
\hline Mean residual & & & -1.37 \\
\hline Root mean square error & & & 2.63 \\
\hline
\end{tabular}


Table 8. Observed minus simulated streamflow residuals of calibrated present steady-state conditions calculated by a groundwater-flow model, southeastern Nassau County, New York.

$[\mathrm{ft} 3 / \mathrm{s}$, cubic foot per second]

\begin{tabular}{lccc}
\hline \multicolumn{1}{c}{ Gage } & $\begin{array}{c}\text { Estimated } \\
\text { value, in } \mathrm{ft}^{3} / \mathbf{s}\end{array}$ & $\begin{array}{c}\text { Simulated } \\
\text { value, in } \mathrm{ft}^{3} / \mathbf{s}\end{array}$ & $\begin{array}{c}\text { Residual, } \\
\text { in } \mathrm{ft}^{3} / \mathbf{s}\end{array}$ \\
\hline Massapequa Creek & 4.66 & 5.70 & 1.04 \\
Seaford Creek & 0.83 & 1.19 & 0.36 \\
Seaman Creek & 2.61 & 1.65 & -0.96 \\
Bellmore Creek & 4.60 & 2.36 & -2.24 \\
\cline { 2 - 4 } Mean & & & -0.45 \\
Root mean square error & & & 1.34 \\
\hline
\end{tabular}

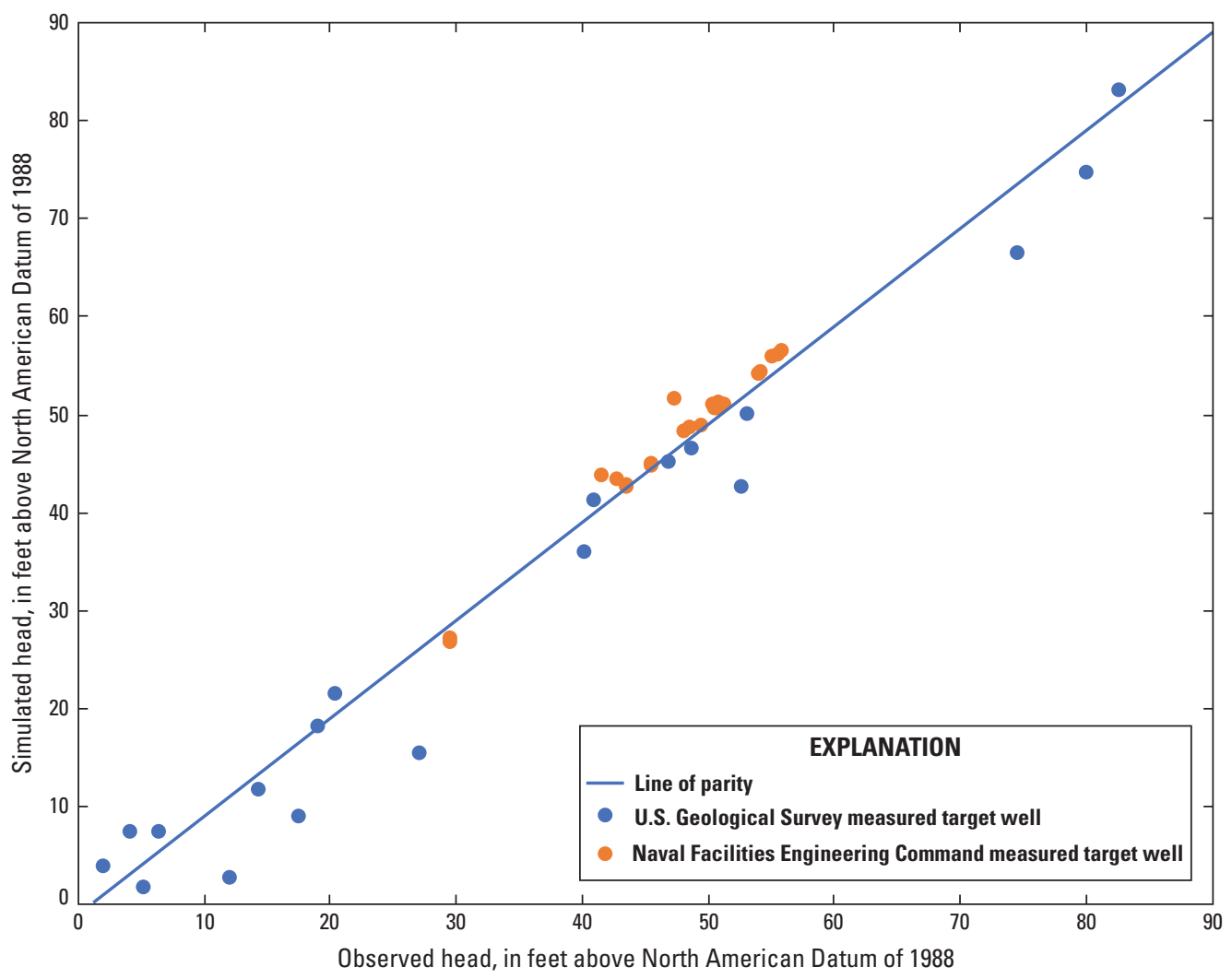

Figure 11. Graph showing the relation between observed and simulated hydraulic heads calculated for present steady-state conditions by a groundwater-flow model, southeastern Nassau County, New York. 
A. Layer 1 1

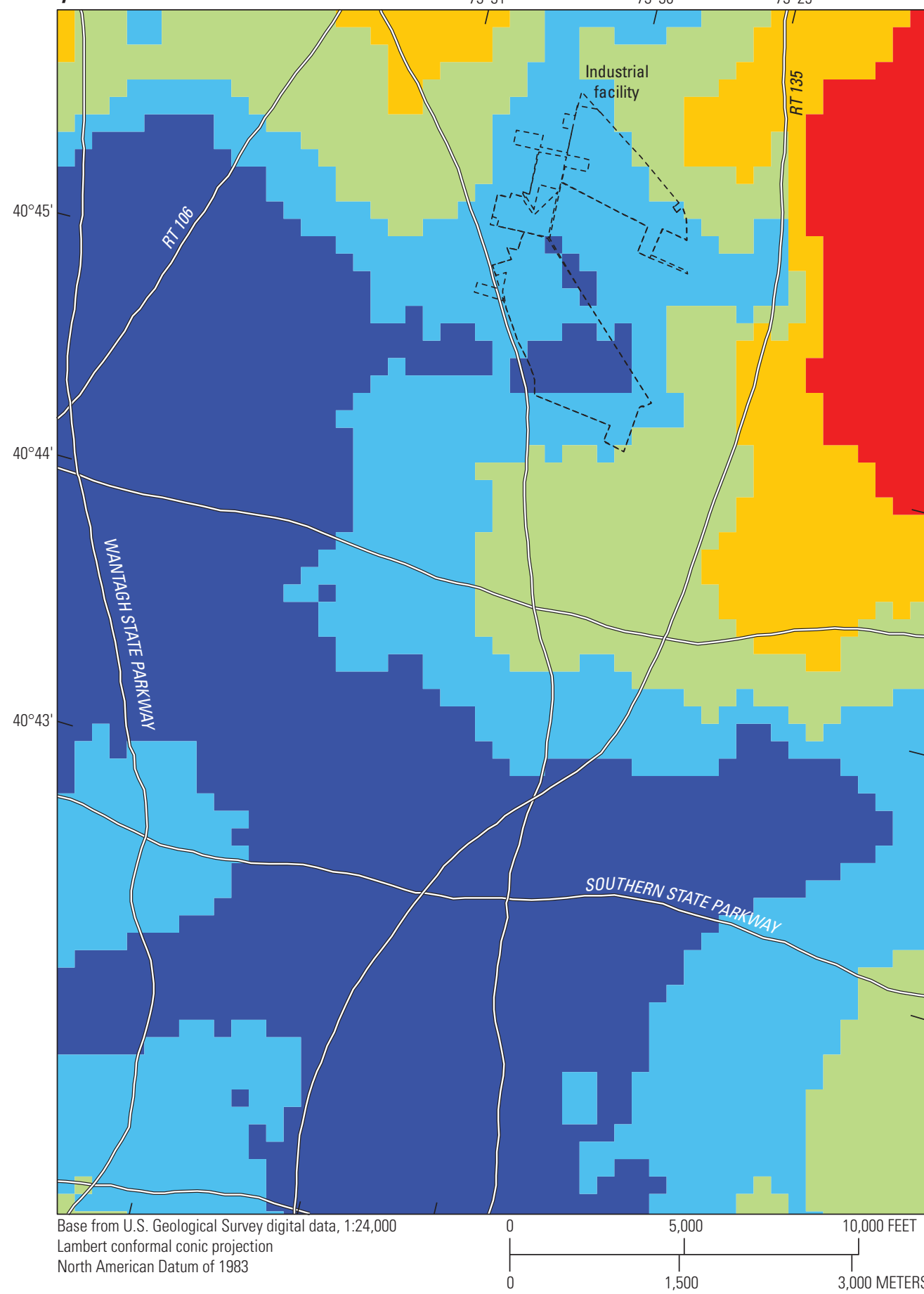

EXPLANATION

Horizontal hydraulic conductivity (Kx) in, $\mathrm{ft} / \mathrm{d}$ $\square \quad 105$ to 156

$\square \quad 157$ to 197

$\square \quad 198$ to 221

222 to 238 239 to 257

Figure 12. Maps showing hydraulic conductivity and the New York State Department of Environmental Conservation (NYSEDC) standards, criteria, and guidance (SCG) plume (HDR, 2019) for model layers 1 and 19, southeastern Nassau County, New York. $A$, Horizontal hydraulic conductivity in layer $1 ; B$, ratio of horizontal to vertical hydraulic conductivity in layer 1 ; $C$, horizontal hydraulic conductivity in layer 19; and $D$, ratio of horizontal to vertical hydraulic conductivity in layer 1. K, hydraulic conductivity; Kx, horizontal hydraulic conductivity; $\mathrm{Kv}$, vertical hydraulic conductivity; $\mathrm{Kx} / \mathrm{Kv}$, ratio of horizontal to vertical hydraulic conductivity; ft/d, foot per day. 
B. Layer 1

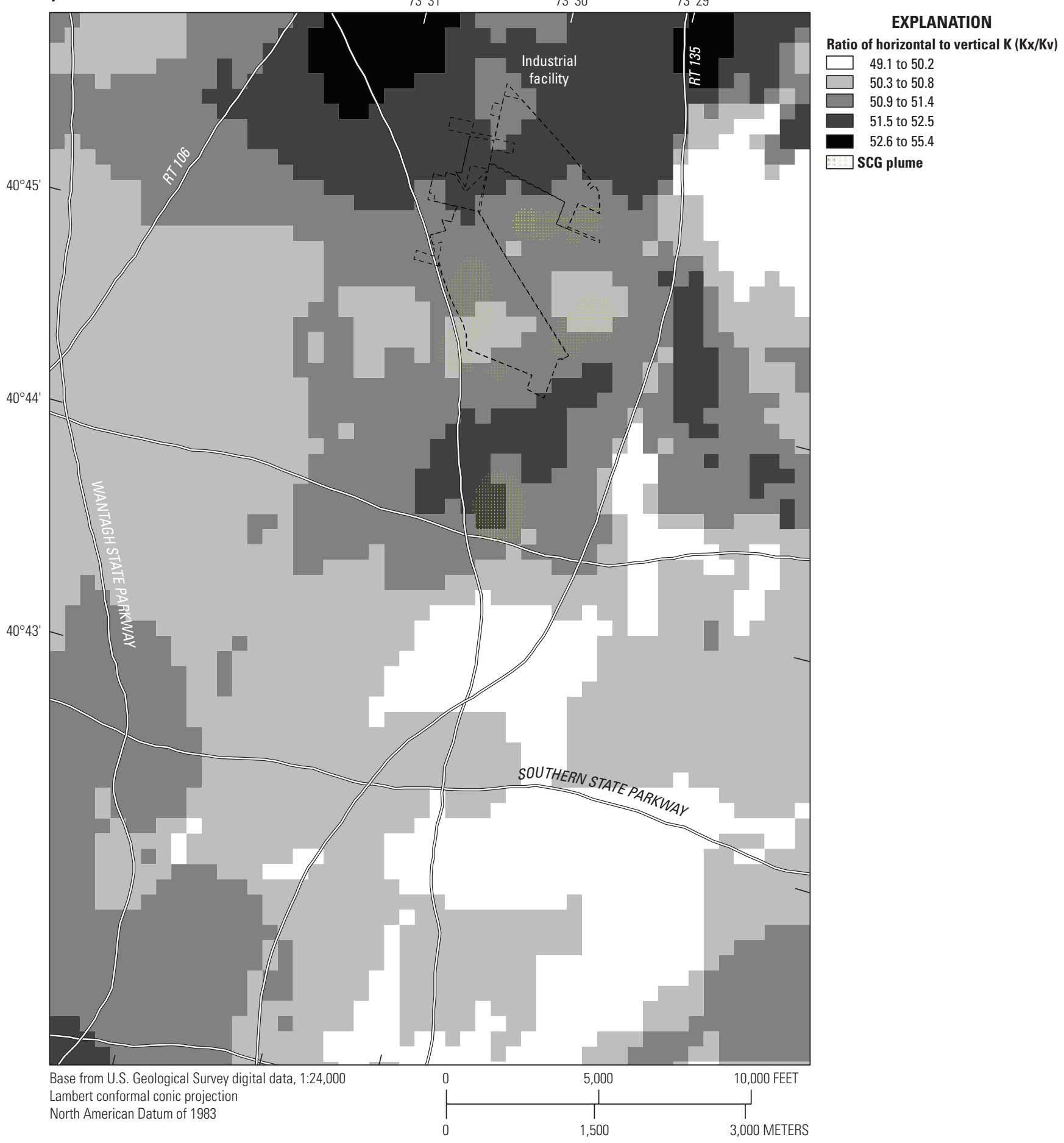

Figure 12. - Continued 
C. Layer 19

c. Layer 19

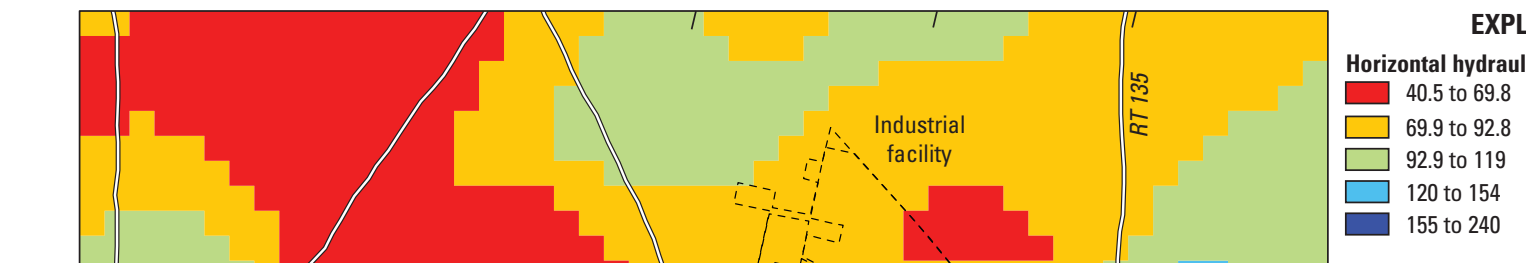

EXPLANATION

( 40.5 to 69.8

155 to 240

$40^{\circ} 44$

$40^{\circ} 4$
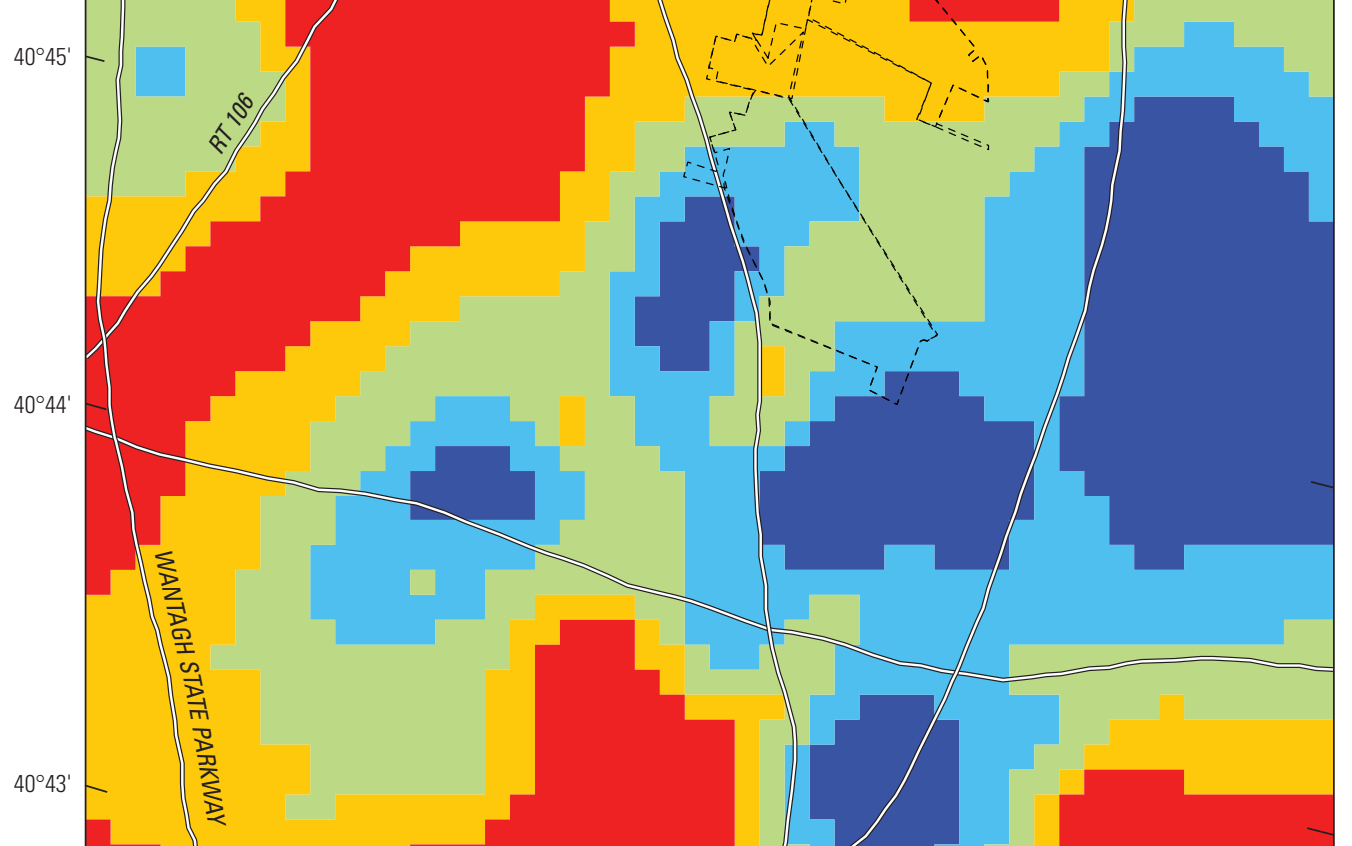

$40^{\circ} 43^{\prime}$
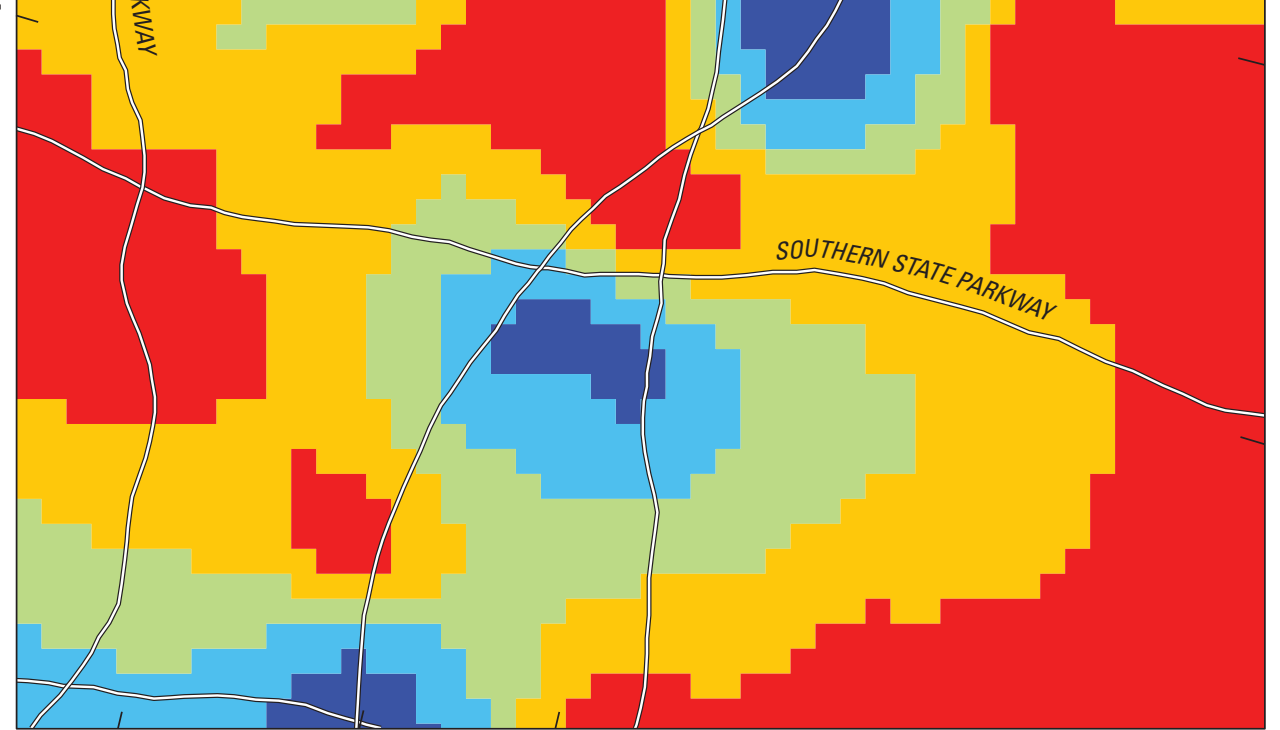

Base from U.S. Geological Survey digital data, 1:24,000

Lambert conformal conic projection

North American Datum of 1983

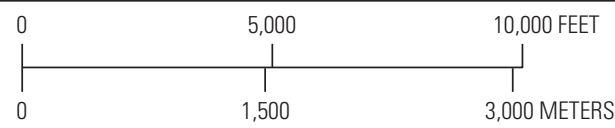

Figure 12. - Continued 
D. Layer 19

$73^{\circ} 31^{1}$

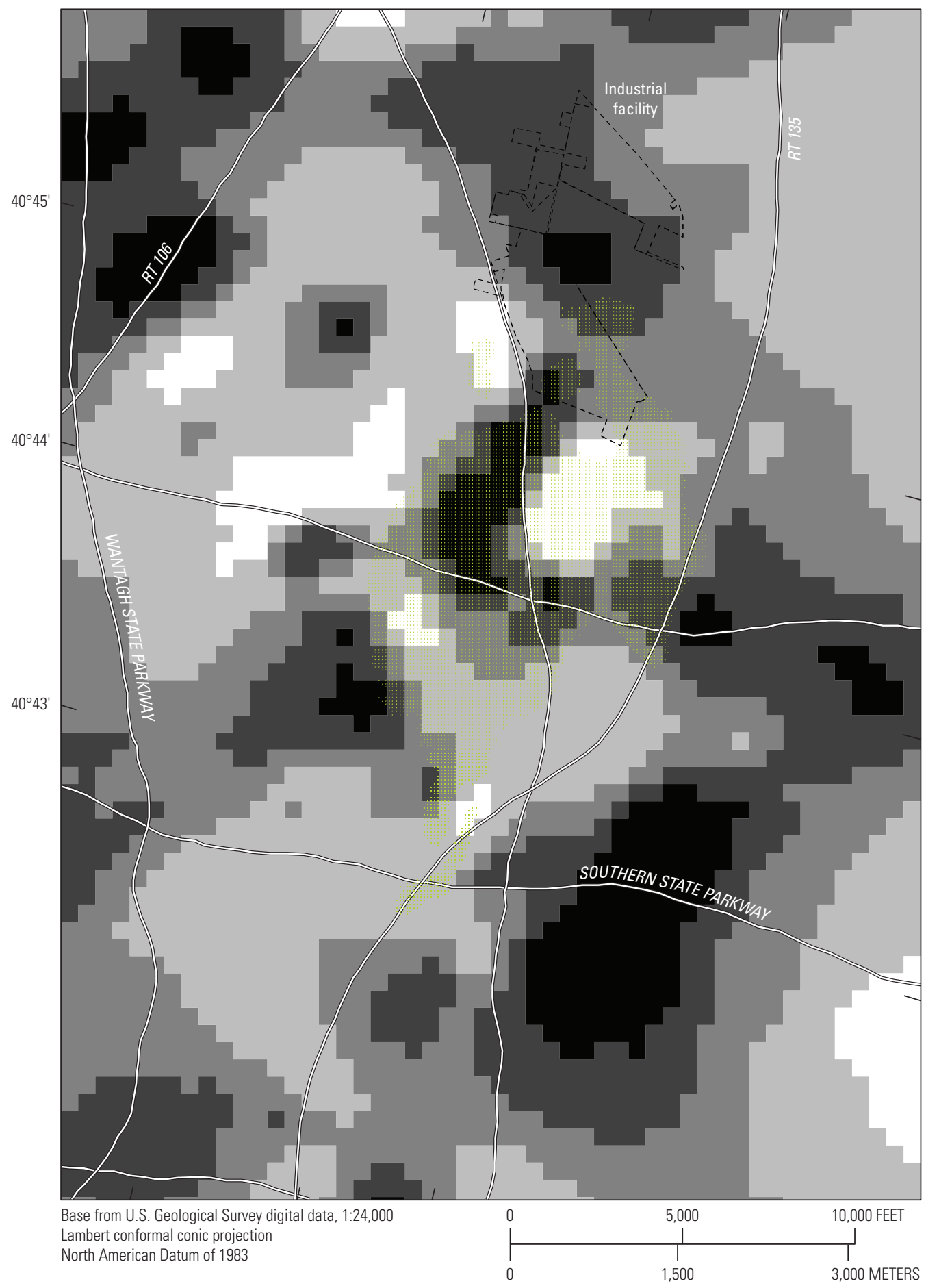

\section{EXPLANATION}

Ratio of horizontal to vertical $\mathrm{K}(\mathrm{Kx} / \mathrm{Kv})$

\begin{tabular}{|l}
$\square \quad 51.3$ to 65.4 \\
$\square \quad 65.5$ to 70.0 \\
70.1 to 73.7 \\
73.8 to 78.3 \\
78.4 to 87.5 \\
$\square$ sCG plume
\end{tabular}

Figure 12. - Continued 


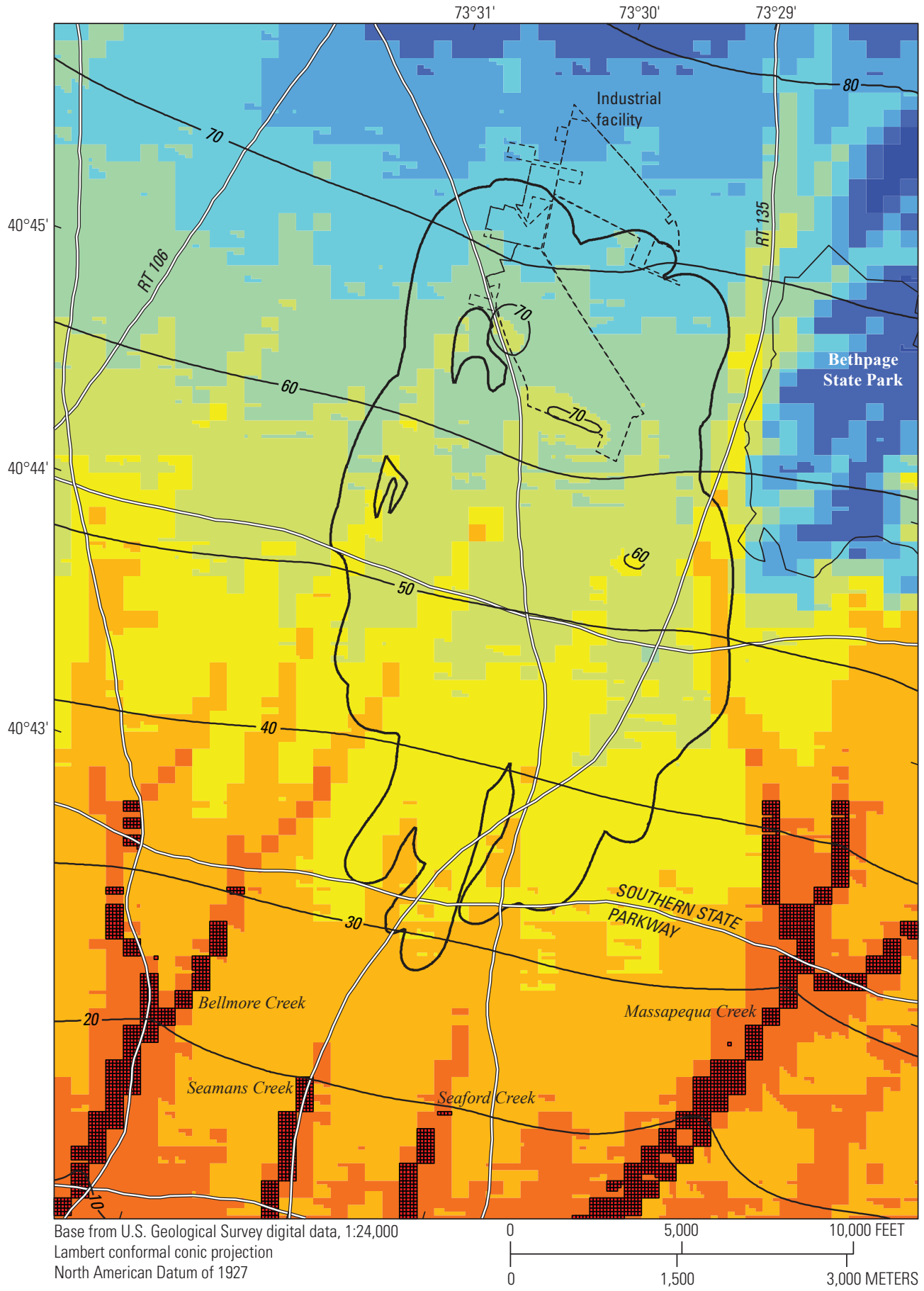

\section{EXPLANATION}

Simulated depth to water, in feetPresent conditions is steady state

-6.67 to 0.0

0.01 to 10.00

10.01 to 20.00

20.01 to 30.00

30.01 to 40.00

40.01 to 50.00

50.01 to 60.00

60.01 to 70.00

70.01 to 80.00

80.01 to 90.00

Model cell with active stream discharge

-30- Simulated water table, in feet above North American Vertical Datum of 1988 - Contour interval 10 feet

- New York State Department of Environmental Conservation standards, criteria, and guidance (SCG) levels plume

Figure 13. Map showing the water table, depth to water, and New York State Department of Environmental Conservation (NYSEDC) standards, criteria, and guidance (SCG) plume under present steady-state conditions (HDR, 2019), southeastern Nassau County, New York. 
Table 9. Water budget under present steady-state conditions simulated by the groundwater-flow model, southeastern Nassau County, New York.

[Fate of lateral focus-zone outflow within southern zones refers to outflow that traverses the boundary separating the focus zone from southern water budget zones (fig. 4). Total outflow within southern zone refers to all discharges within southern water-budget zones (fig. 4) including water originating within the focus-zone and water originating from other sources. Reverse-gradient inflows at seawater boundaries refers to reverse-gradient inflows at general-head boundaries within southern water budget zones (fig. 4); totals may not reflect the sum of values shown due to rounding]

\begin{tabular}{|c|c|c|}
\hline Water budget term & Flow, in gallons per minute & $\begin{array}{c}\text { Percentage of total focus-zone } \\
\text { outflow }\end{array}$ \\
\hline \multicolumn{3}{|c|}{ Outflow within focus zone } \\
\hline Focus-zone pumpage & 26,657 & 57 \\
\hline Focus-zone stream discharge & 5,319 & 11 \\
\hline Focus-zone lateral outflow & 15,161 & 32 \\
\hline Total focus-zone outflow & 47,139 & 100 \\
\hline \multicolumn{3}{|c|}{ Fate of lateral focus-zone outflow within southern zones } \\
\hline Coastal & 2,485 & 5 \\
\hline Magothy aquifer & 9,341 & 20 \\
\hline Lloyd aquifer & 189 & 0 \\
\hline Total & 12,016 & 25 \\
\hline \multicolumn{3}{|c|}{ Total outflow within southern zone } \\
\hline Stream discharge & 3,327 & 7 \\
\hline Shoreline and seafloor discharge & 21,560 & 46 \\
\hline Magothy aquifer subsea discharge & 496 & 1 \\
\hline Lloyd aquifer subsea discharge & 0 & 0 \\
\hline Total & 25,383 & 54 \\
\hline \multicolumn{3}{|c|}{ Inflow within focus zone } \\
\hline Focus-area recharge & 31,007 & 66 \\
\hline Focus-area wastewater inflow & 5,518 & 12 \\
\hline Focus-area lateral inflow & 10,212 & 22 \\
\hline Total focus-area inflow & 46,737 & 99 \\
\hline \multicolumn{3}{|c|}{ Reverse-gradient inflow at seawater boundaries } \\
\hline Shoreline and seafloor & 948 & 2 \\
\hline Magothy aquifer subsea inflow & 150 & 0 \\
\hline Lloyd aquifer subsea inflow & 147 & 0 \\
\hline Total & 1,245 & 3 \\
\hline
\end{tabular}




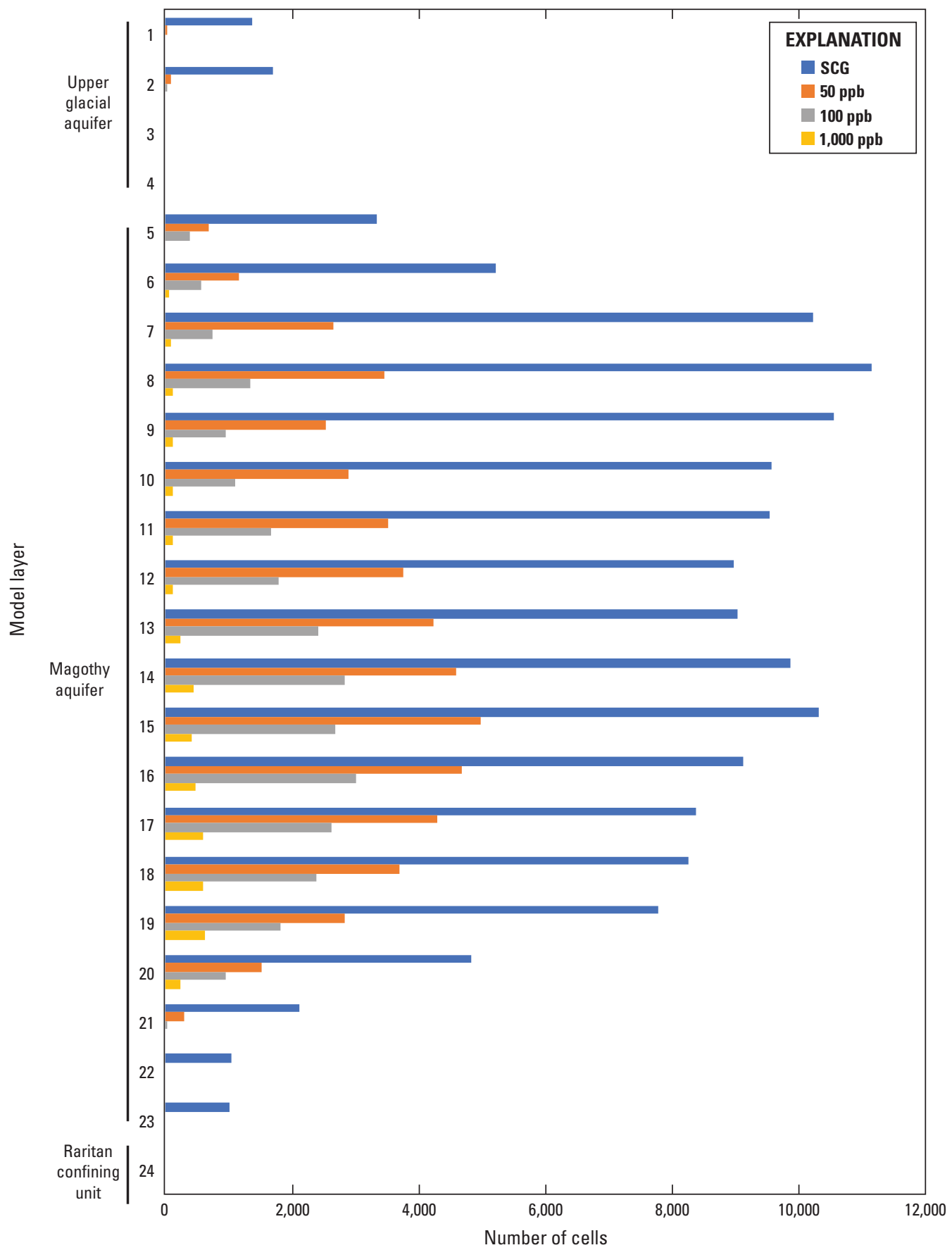

Figure 14. Graph showing number of model cells per layer that intersect the standards, criteria, and guidance (SCG), total chlorinated volatile organic compound (TCVOC) greater than (>) 50-part-per-billion (ppb), TCVOC >100-ppb, and TCVOC >1,000-ppb plumes (HDR, 2019) in southeastern Nassau County, New York. 


\section{Analysis of Remedial Scenarios Affecting Plume Movement}

The design and structuring of scenarios to remediate plume zones are motivated by goals related to hydraulic capture of plumes as represented by MODPATH analysis and other factors including controlled recharge of treated water; capture of the maximal proportion of the plume mass; minimal disturbance of wetlands, streams, estuaries, and subsea discharge; the timing of capture; and engineering considerations. In addition to MODPATH analysis, simulation of water-level and water-flux changes are also considered, including analysis of uncertainties. Remedial pumping is balanced with treated-water recharge at surface basins or injection wells; thus, water-table mounding under added recharge basins is also considered.

In general, MODPATH particles started within plumes end at remedial pumping wells, other pumping wells, surface-water receptors, or subsea-discharge boundaries. Remedial- design strategy entails hydraulic capture of all particles by remedial-design wells, remedial systems that are currently operating or planned to operate in the near future, or other pumping wells nearby or within a plume. An iterative approach was used with intermediate particle pathline graphics guiding the adjustment of pumping rates, locations, and screen zones of proposed wells until all pathlines ended at desired receptors without particles escaping towards discharge to surface-water receptors or downgradient to public-supply wells. A graphical user interface was developed to facilitate these iterations.

Beyond particle-tracking analysis, other factors were considered in the remedial alternative analysis, including engineering feasibility. Some scenarios enhance the hydrauliccontainment approach with other remedial-well types that are specified to achieve maximum mass capture, quickly flush the aquifer, or intercept particles moving toward other wells. Introduction of the mass-flux and aquifer-flushing well types generally increases the total amount of remedial pumping necessary to achieve total hydraulic capture of plume particles because of the steady-state nature of and the absence of mass conservation in the MODPATH approach.

To explore factors that affect the fate, transport, and remediation of plumes, eight scenario versions (table 10) were modeled in addition to a near-future baseline condition (scenario 1). Scenario 1 represents steady-state current conditions (2010-2015) with additional near-term remedial action and is evaluated with respect to control of an SCG plume. Nearterm planned systems include the RE-108 and RW-21 hotspot remediation systems to address TCE source areas identified in the western and eastern areas of the SCG plume, respectively. Scenario 2 represents a remedial system that is optimized to capture site contaminants above the SCG plume, with return of treated water to the land surface by using distributedrecharge basins, Massapequa Creek flow-augmentation alone, or in combination with a centralized recharge basin. Creekflow augmentation is represented by water injection into a model cell that also represents the creek flow. Scenario 3 represents a remedial system that is optimized to capture site contaminants above $50 \mathrm{ppb}$ TCVOC, returns water through distributed recharge basins alone or in combination with a centralized recharge basin and the capture of highly concentrated parts of plumes. Scenario 4 represents a remedial system that is optimized to capture site contaminants above $100 \mathrm{ppb}$ TCVOC, returns water through distributed recharge basins and injection wells, and includes a focus on the capture of highly concentrated parts of plumes. Scenario 5 represents a remedial system that is optimized to capture contaminants above health standards and that is optimized to return water through distributed recharge basins and either Massapequa Creek flow-augmentation alone or in combination with a centralized recharge basin.

Mean particle travel times from plume starting position to discharge (table 11) are affected by the following scenario characteristics: number of remedial wells, plume-body volume, treated-water recharge technique, and degree of focus on the capture of highly concentrated parts of plumes. As the volume of the plume body to be contained decreases, SCG values for concentrations of TCVOC double from 50 to $100 \mathrm{ppb}$, and particle numbers and travel times decrease. The present-conditions, steady-state, and scenario 1 simulations indicate that the SCG plume is not hydraulically contained, and therefore the mean travel time to discharge is longer for these cases.

Change in hydraulic head from the baseline (whose present condition is steady state) to other scenarios may be positive or negative at selected observation points (table 12). Hydraulic- head change at many wells within the SCG plume varies between negative and positive depending on the scenario and the proximity to scenario stresses. Hydraulic heads at hypothetical observation points near the freshwater/saltwater transition zone do not change significantly (less than $1 \mathrm{ft}$ ). Hydraulic heads anticipated in scenario 1 for remediated water basins increases from the present steady-state condition. Remedial treated-water basin flows are represented as water injection into underlying model cells without loss. Hydraulic heads at public-supply wellfields downgradient from the Southern State Parkway and SCG plume (well IDs N 13338, N 6867, N 6442, and N 8837) increase slightly in response to most scenarios. Hydraulic-head and streamflow- calibration targets for the present-conditions steady-state model are shown in tables 7 and 8, respectively.

The effects of remedial scenarios on distant regional model-boundary conditions are minimal and generally within the margin of error associated with model-convergence criteria because of the balanced return of all remedial pumpage to nearby recharge locations (table 13). Scenarios mostly result in redistribution of water from deep parts of the Magothy aquifer where pumping occurs to the water-table aquifer and towards the south (where recharge basins are typically found). During scenarios that hydraulically contain the SCG plume (scenarios 2 and 5), water-table mounds extend, at low levels, to a south-shore general head (the coastline) and to drain (stream) boundaries within the water-table aquifer. 

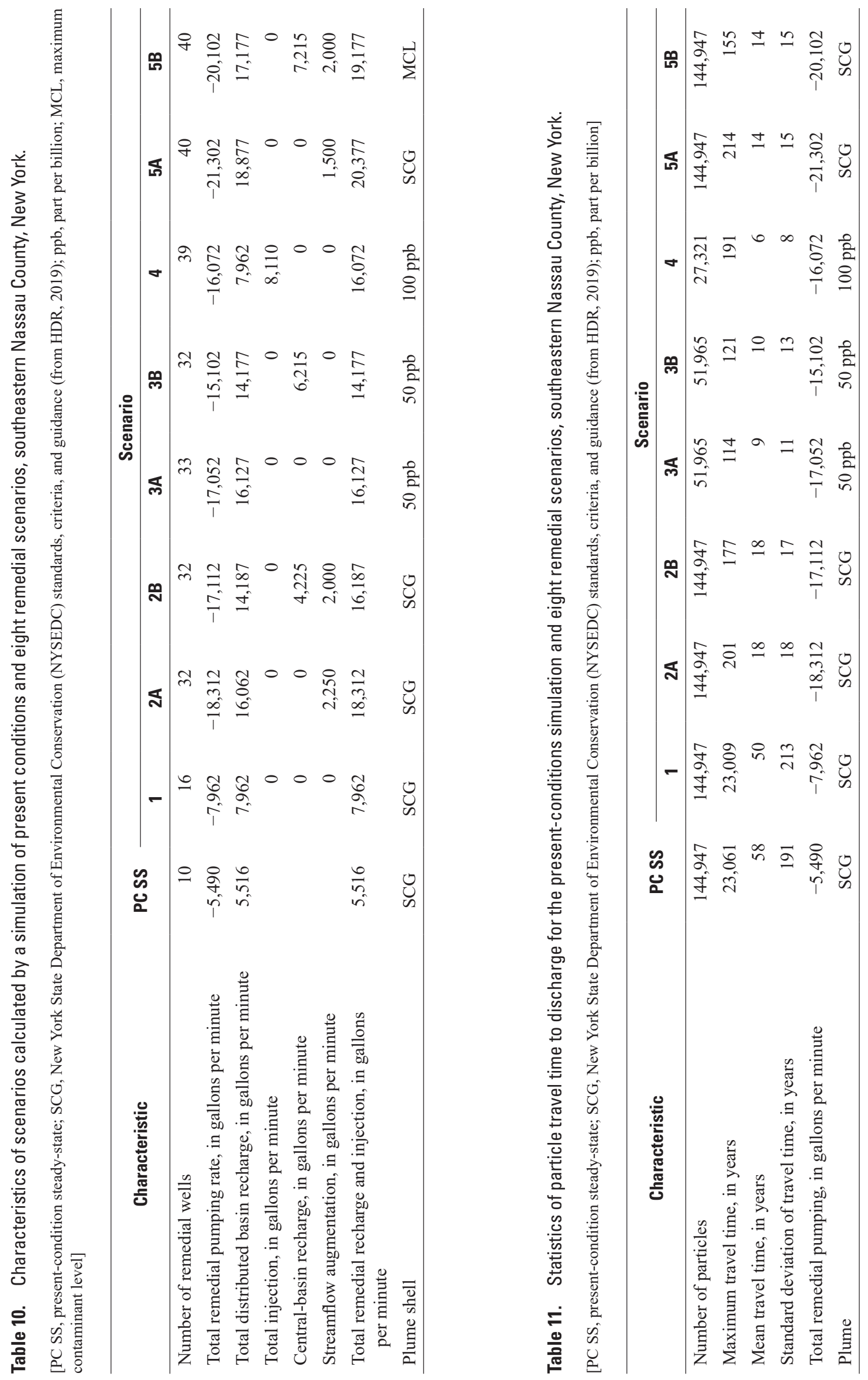
Table 12. Simulated water levels and streamflows under present conditions and remedial scenarios, southeastern Nassau County, New York.

[Water levels are in feet above the North American Vertical Datum of 1988; streamflow is listed in cubic feet per second. Locations shown in figures 5 and 6; available observations are described in tables 4 and 5. WD, water district; NAWQA, National Water-Quality Assessment; NAVFAC, Naval Facilities Engineering Command; PC SS, present-conditions steady-state]

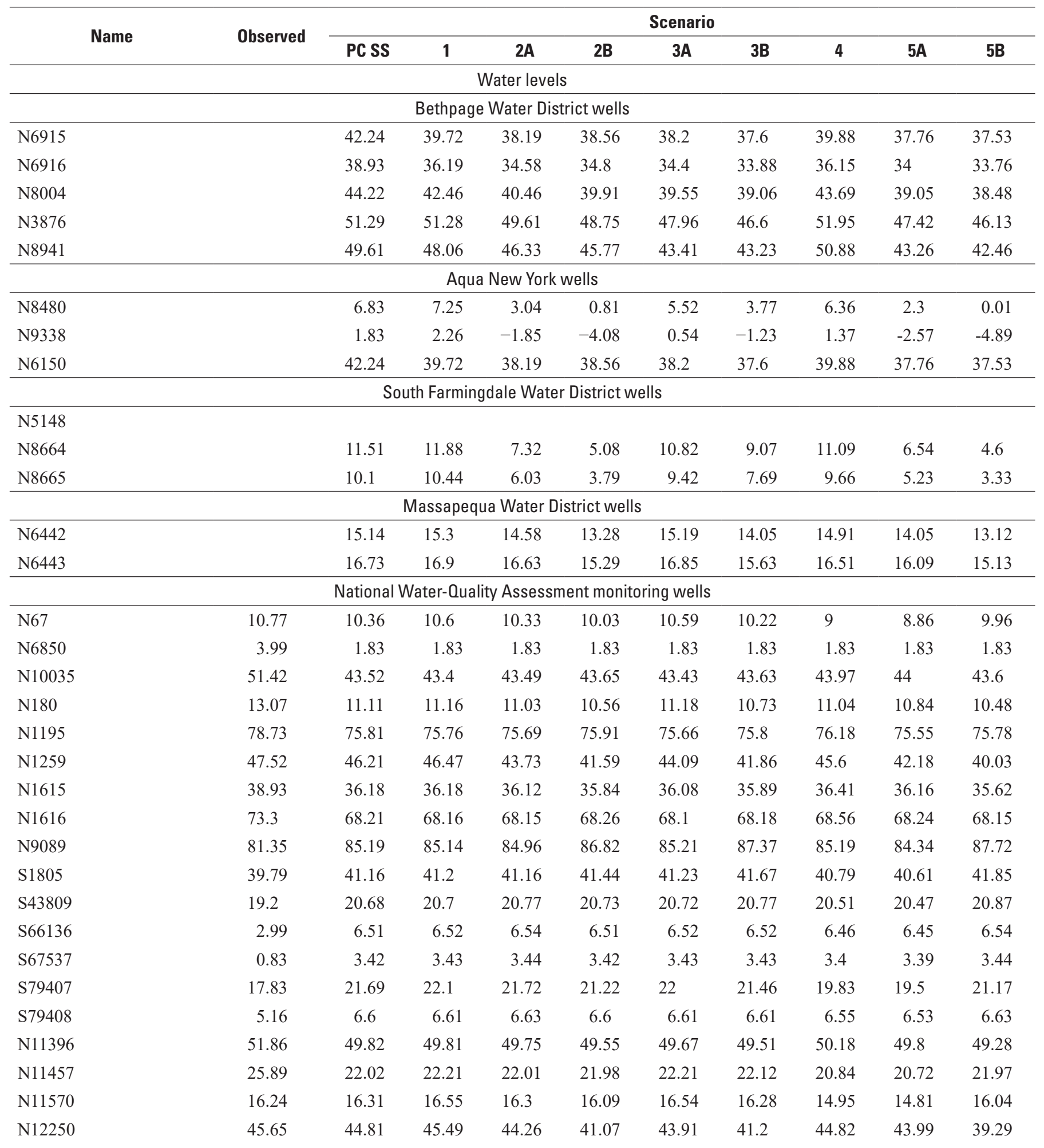


Table 12. Simulated water levels and streamflows under present conditions and remedial scenarios, southeastern Nassau County, New York.-Continued

[Water levels are in feet above the North American Vertical Datum of 1988; streamflow is listed in cubic feet per second. Locations shown in figures 5 and 6; available observations are described in tables 4 and 5. WD, water district; NAWQA, National Water-Quality Assessment; NAVFAC, Naval Facilities Engineering Command; PC SS, present-conditions steady-state]

\begin{tabular}{|c|c|c|c|c|c|c|c|c|c|c|}
\hline \multirow{2}{*}{ Name } & \multirow{2}{*}{ Observed } & \multicolumn{9}{|c|}{ Scenario } \\
\hline & & PC SS & 1 & $2 A$ & 2B & $3 A$ & 3B & 4 & $5 A$ & 5B \\
\hline \multicolumn{11}{|c|}{ Naval Facilities Engineering Command monitoring wells } \\
\hline BPOW1_2 & 40.28 & 43.46 & 43.34 & 39.62 & 38.8 & 42.92 & 41.18 & 42.74 & 39.19 & 39.66 \\
\hline BPOW6_1 & 28.38 & 26.45 & 26.71 & 24.26 & 22.56 & 26.31 & 24.77 & 26.14 & 23.65 & 22.25 \\
\hline RE103D1 & 52.92 & 53.56 & 52.11 & 50.55 & 49.85 & 47.23 & 46.54 & 53.8 & 46.56 & 45.59 \\
\hline RE103D2 & 52.87 & 53.53 & 52.06 & 50.5 & 49.8 & 47.16 & 46.49 & 53.78 & 46.5 & 45.54 \\
\hline RE103D3 & 52.78 & 53.46 & 52.22 & 50.64 & 49.95 & 47.49 & 46.83 & 53.78 & 46.81 & 45.87 \\
\hline RE105D1 & 49.87 & 50.4 & 49.45 & 47.43 & 46.37 & 43.7 & 42.68 & 48.41 & 42.96 & 41.7 \\
\hline RE105D2 & 49.24 & 49.67 & 48.32 & 46.29 & 45.33 & 43.5 & 42.73 & 47.19 & 42.77 & 41.64 \\
\hline RE115D1 & 42.3 & 42.1 & 41.64 & 37.4 & 35.28 & 38.64 & 37.04 & 39.65 & 35.84 & 33.6 \\
\hline RE115D2 & 42.37 & 41.72 & 41.11 & 36.66 & 34.65 & 37.97 & 36.51 & 38.94 & 34.99 & 32.92 \\
\hline RE120D1 & 49.51 & 50.15 & 49.27 & 47.25 & 45.9 & 43.46 & 42.21 & 46.14 & 42.37 & 40.76 \\
\hline RE120D2 & 49.54 & 49.97 & 49.02 & 46.95 & 45.62 & 43.78 & 42.56 & 45.94 & 42.67 & 41.07 \\
\hline RE120D3 & 49.49 & 49.95 & 48.99 & 46.91 & 45.59 & 43.92 & 42.71 & 46.23 & 42.8 & 41.22 \\
\hline RE122D1 & 54.58 & 55.88 & 55.29 & 53.9 & 53.54 & 50.67 & 50.09 & 56.34 & 49.89 & 49.28 \\
\hline RE122D2 & 54.32 & 55.33 & 54.52 & 53.08 & 52.73 & 49.93 & 49.43 & 55.79 & 49.18 & 48.58 \\
\hline RE122D3 & 53.9 & 55.17 & 54.31 & 52.84 & 52.5 & 50.11 & 49.64 & 55.82 & 49.33 & 48.76 \\
\hline TT_101D & 48.31 & 48.87 & 49 & 46.86 & 44.98 & 45.04 & 43.11 & 47.59 & 43.77 & 41.62 \\
\hline TT_101D1 & 47.32 & 48.14 & 46.68 & 44.24 & 42.64 & 41.48 & 40.01 & 43.73 & 40.05 & 38.23 \\
\hline TT_101D2 & 46.92 & 47.57 & 46.32 & 43.71 & 42.16 & 41.79 & 40.43 & 43.28 & 40.23 & 38.49 \\
\hline \multicolumn{11}{|c|}{ Streamflow } \\
\hline Massapequa Creek & -4.66 & -5.53 & -5.54 & -8.93 & -6.44 & -5.75 & -4.68 & -4.96 & -6.86 & -6.74 \\
\hline Seaford Creek & -0.83 & -1.2 & -1.22 & -1.22 & -1.05 & -1.23 & -1.07 & -1.17 & -1.14 & -1.03 \\
\hline Seaman Creek & -2.61 & -1.72 & -1.75 & -1.73 & -1.53 & -1.77 & -1.56 & -1.69 & -1.65 & -1.5 \\
\hline Bellmore Creek & -4.6 & -2.26 & -2.4 & -2.05 & -1.4 & -2.27 & -1.61 & -2.21 & -1.83 & -1.25 \\
\hline
\end{tabular}


Table 13. Simulated steady-state-zone budget terms of focus-area model under present conditions and remedial scenarios, New York.

[Values are in gallons per minute. Fate of lateral focus-zone outflow within southern zones refers to outflow that traverses the boundary separating the focus zone from southern water budget zones (fig. 4). Total outflow within southern zone refers to all discharges within southern water-budget zones (fig. 4) including water originating within the focus-zone and water originating from other sources. Reverse-gradient inflows at seawater boundaries refers to reverse-gradient inflows at general-head boundaries within southern water budget zones (fig. 4); totals may not reflect the sum of values shown due to rounding. PC SS, present-conditions steady state]

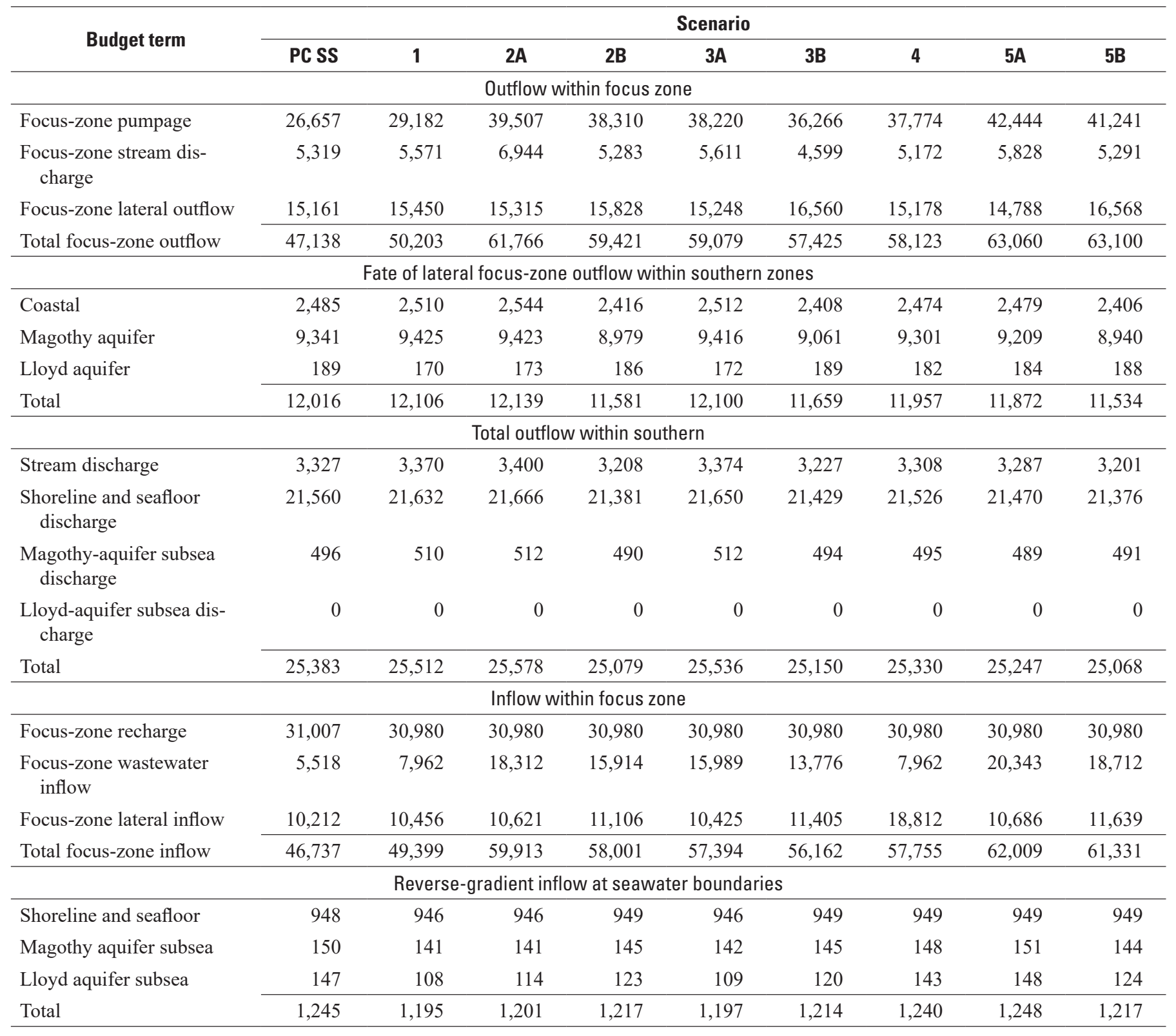




\section{Scenario 1}

The purpose of remedial scenario 1 is to provide a baseline by which to judge other remedial alternative scenarios, but not to completely remediate the plume. Scenario 1 is a combination of a steady-state simulation of the present conditions (2010 to 2015; simulated water table shown in fig. 7) and near-term future remedial stresses (table 14). The present-conditions simulation consists of 10 remedial wells with a total pumping rate of $5,205 \mathrm{gal} / \mathrm{min}$. Water pumped at this rate is discharged as treated water at four recharge-basin systems. Remedial scenario 1 adds to the present-conditions steady-state simulation six remedial wells (fig. 15) that are anticipated to be implemented in the near future to address areas with concentrations of VOCs several orders of magnitude above the SCG identified in the deepest part of the plume. Specifically, the remedial wells are referred to as the RE108 system wells on the western part of the SCG plume and wells RW-20, RW-21, and RW-22 on the eastern part of the SCG plume (fig. 15). These additional remedial wells are anticipated to have a combined pumping rate of approximately $3,400 \mathrm{gal} / \mathrm{min}$, with the total remedial pumping rate anticipated to be approximately 7,962 $\mathrm{gal} / \mathrm{min}$ (table 10). Scenario 1 remedial pumpage is discharged as treated water into six recharge basins.

During the present-conditions and scenario 1 simulations, particles started within the SCG plume escape beyond the plume shell, are captured by remedial wells, or are captured by public-supply wells (fig. 16). Some particles travel over long distance and time, entrained in a regional upflow zone or captured by public-supply wells screened in the Lloyd aquifer near Long Beach (fig. 4; statistics of total travel time for the population of pathlines given in table 11). In general, pathlines with travel times of 5 years or less (indicated as red pathlines; fig. 16) are situated near pumping wells of either remedial systems or public- supply wells situated within the plume. In the outer reaches of well zones of influence, particles may be drawn towards the well but not captured. Compared to the present steady-state conditions, scenario 1 pathlines are generally shorter in length and duration (about 10 years shorter on average; table 11) and more likely to be captured by wells within the plume shell; however, particles continue to escape the plume shell to ultimately discharge at surface-water receptors. Additional illustrations of particle pathlines are in Misut (2020).

Environmental effects of scenario 1 include groundwater mounding beneath recharge basins, cones of depression near pumping stresses, and changes in discharge to creeks. Simulation of scenario 1 stresses results in changes from the present-conditions simulation (fig. 17; tables 12 and 13). Maximum water-table mounding of $8.9 \mathrm{ft}$ occurs near treatedwater recharge basins added during scenario 1 . Characteristics of regional-upflow zones that entrain particles into eventual discharge at the coast do not change from present conditions to scenario 1. Slight changes in net total shoreline- or subsea-discharge amounts (table 13) are less than what could be accurately simulated given the numerical-model convergence criteria.

Table 14. Well-pumping rates in southeastern Nassau County, New York, under scenario 1.

[Pumping rates are listed in gallons per minute; screen top and bottom elevations listed in feet above the North American Vertical Datum of 1988; coordinate locations listed in State plane feet (Long Island zone) relative to the North American Datum of 1927]

\begin{tabular}{|c|c|c|c|c|c|}
\hline Remedial well number & $\mathbf{X}$ & $\mathbf{Y}$ & Rate & Screen top & Screen bottom \\
\hline OU3 RW1 & $2,142,117$ & 192,933 & 30 & 16 & -4 \\
\hline OU3 RW2 & $2,142,439$ & 192,911 & 66 & 40 & 20 \\
\hline OU3 RW4 & $2,142,942$ & 192,845 & 30 & 11 & -9 \\
\hline GM38 RW1 & $2,139,170$ & 189,320 & 600 & -407 & -458 \\
\hline OU2 RW18 & $2,141,520$ & 188,031 & 869 & -362 & -466 \\
\hline OU2 RW19 & $2,142,790$ & 188,625 & 726 & -361 & -622 \\
\hline OU2 RW3 & $2,145,475$ & 184,589 & 941 & -249 & -344 \\
\hline RE108i & $2,140,838$ & 184,816 & 400 & -457 & -557 \\
\hline RW21 & $2,144,325$ & 187,330 & 500 & -432 & -527 \\
\hline RW22 & $2,145,096$ & 184,993 & 500 & -513 & -627 \\
\hline Total & & & 7,962 & & \\
\hline
\end{tabular}




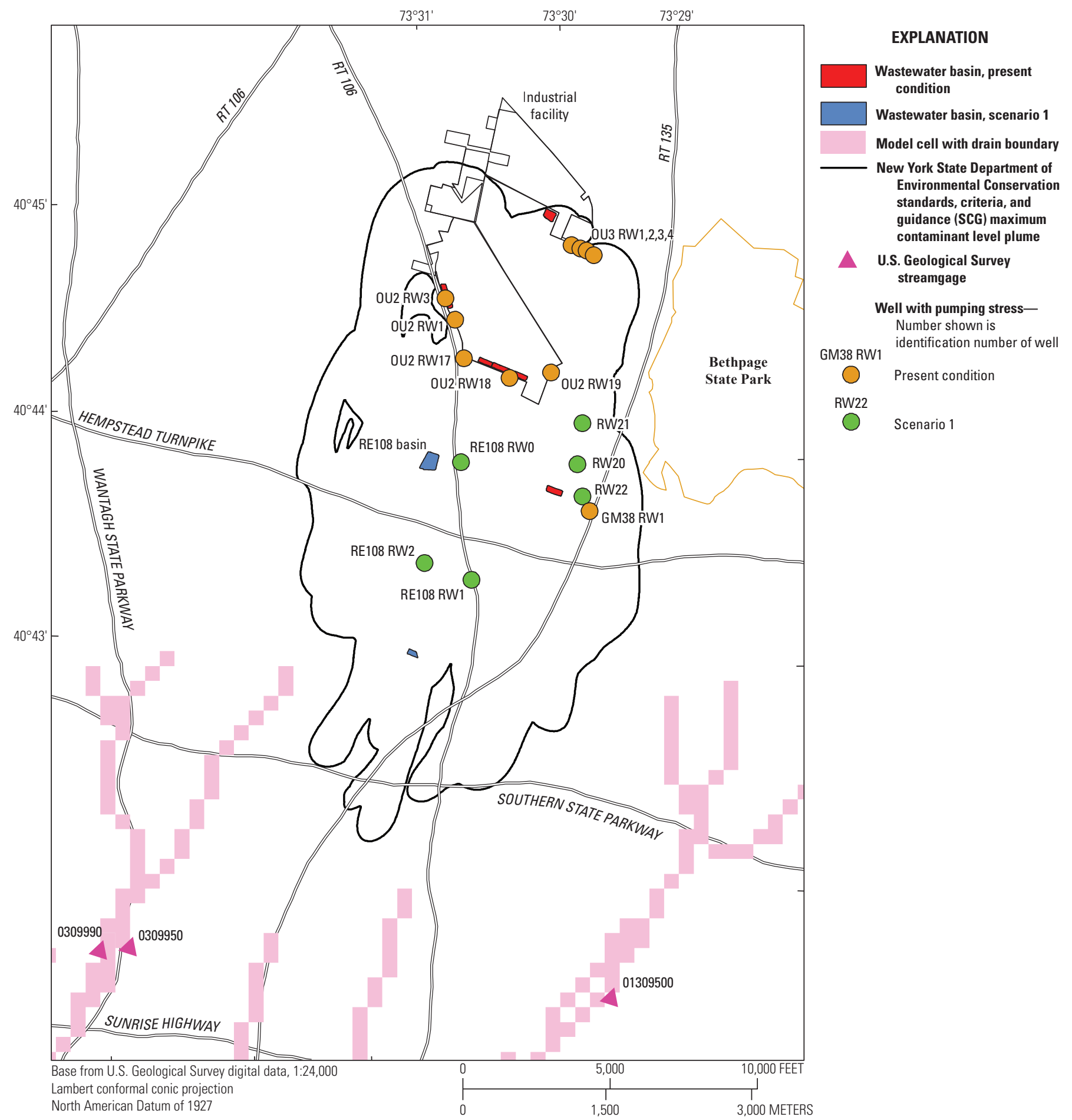

Figure 15. Map showing stress locations for remedial well pumping under present conditions and scenario 1 in southeastern Nassau County, New York. 


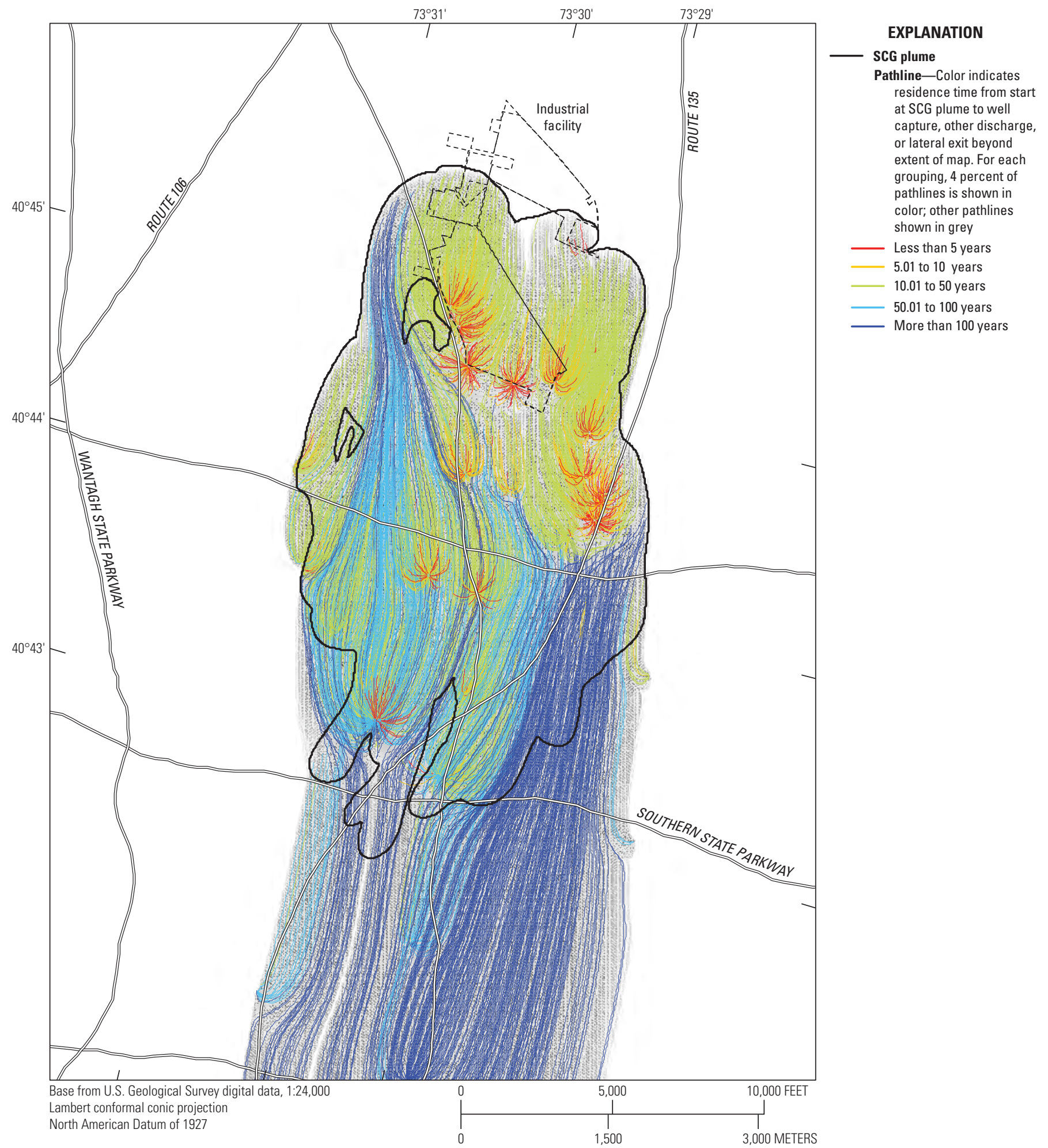

Figure 16. Map showing the New York State Department of Environmental Conservation (NYSEDC) standards, criteria, and guidance (SCG) plume shell (HDR, 2019) and scenario 1 particle pathlines started at the plume shell, southeastern Nassau County, New York. A high-resolution version of this figure is available for download at https://doi.org/10.3133/sir20205090. 


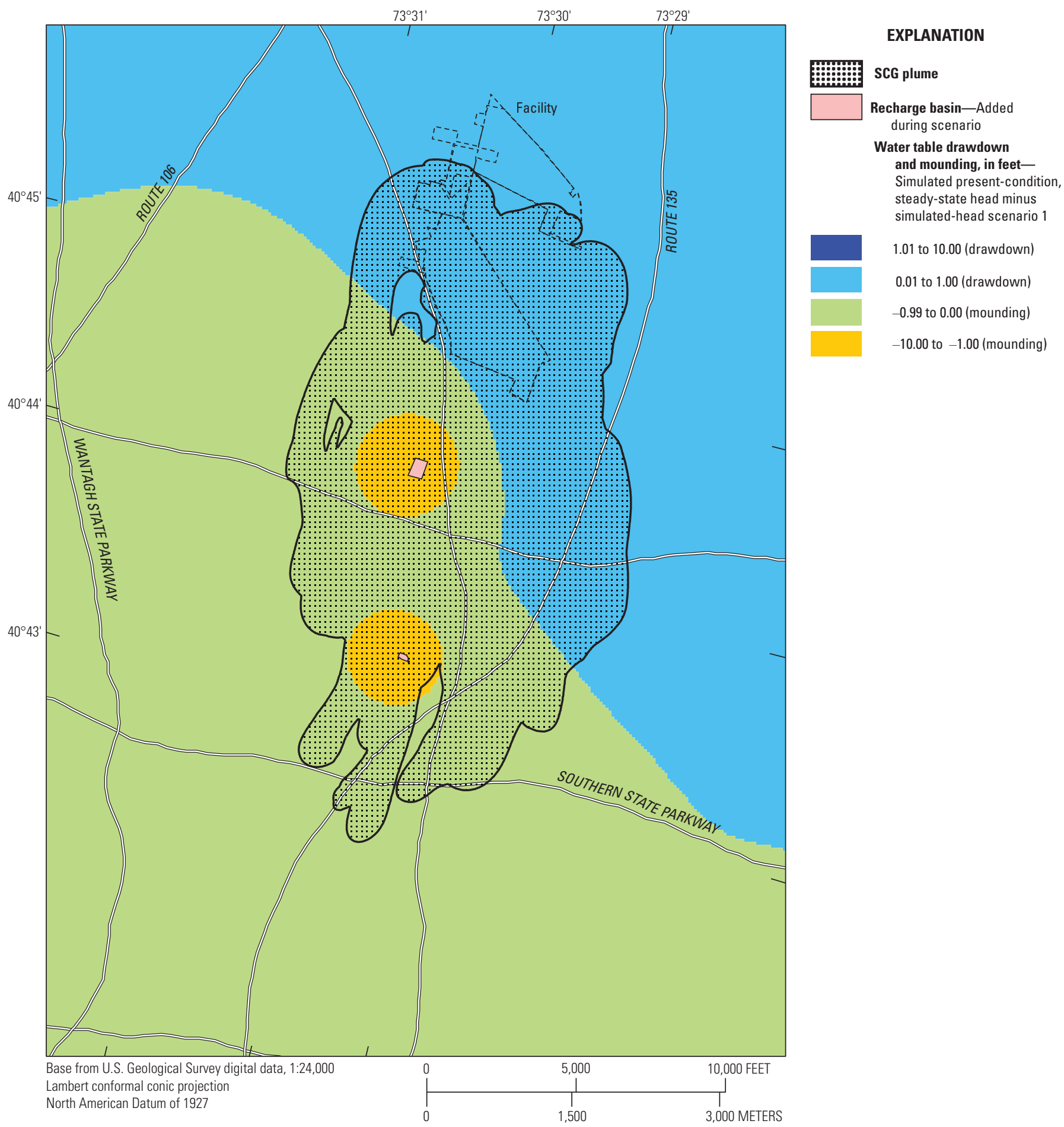

Figure 17. Map showing scenario 1 locations of treated-water return and simulated water-table change from present conditions, southeastern Nassau County, New York. SCG, New York State Department of Environmental Conservation (NYSEDC) standards, criteria, and guidance (SCG). 


\section{Scenario 2}

The purpose of remedial scenarios $2 \mathrm{~A}$ and $2 \mathrm{~B}$ is to hydraulically contain all contaminants above SCG standards with a minimum of pumpage. These scenarios add 16 wells to scenario 1 for a total of 32 wells (table 15). Scenario 2A returns 2,250 gal/min of treated water to Massapequa Creek and $16,062 \mathrm{gal} / \mathrm{min}$ to the land surface by using distributedrecharge basins (table 10). Scenario 2B implements a centralized recharge basin that handles $4,225 \mathrm{gal} / \mathrm{min}$ or about 30 percent of the total volume of water treated (table 10), with $14,187 \mathrm{gal} / \mathrm{min}$ placed in distributed-recharge basin flows and 2,000 gal/min used for streamflow augmentation. Some remedial-well pumping rates near the eastern edge of the plume are slightly reduced from scenario $2 \mathrm{~A}$ to scenario $2 \mathrm{~B}$ to counterbalance the effects of the centralized recharge basin. Some remedial-well pumping rates near the western edge of the plume were also slightly increased from scenario $2 \mathrm{~A}$ to scenario 2B. The centralized recharge basin in the Bethpage State Park is in an area with a thick unsaturated zone that may accommodate greater mounding than an area near the leading edge of the plume, where the unsaturated zone is relatively thin.

During the scenario 2 simulations, all particles started within the SCG plume are captured by remedial or publicsupply wells within the plume footprint (fig. 18). Compared with scenario 1, pathlines are significantly shorter in length and duration because of complete plume containment by remedial wells and zero discharge to points south of the model focus, including the Lloyd aquifer wells at Long Beach. Particles are generally captured by nearby remedial wells within short travel times (red pathline color; fig. 18); however, some pathlines are situated above or below the capture zones of nearby remedial wells and continue over longer distances and travel times before ultimate capture by remedial wells that are near the leading edge of the plume (blue pathline color; fig. 18). During scenario 2B, as a result of the central recharge basin at Bethpage State Park, the cone of depression that forms around the entire group of remedial wells is shifted away from Bethpage State Park, and pathlines take on a more east-to-west trajectory as compared to those produced under scenario 2A. Additional illustrations of particle pathlines are in Misut (2020).

Environmental effects (fig. 19; tables 12 and 13) during scenario 2 include groundwater mounding beneath recharge basins, cones of depression near pumping stresses, and changes in discharge to creeks. Maximum water-table mounding of $21.7 \mathrm{ft}$ occurs near the upstream point of streamflow augmentation. Water-table mounding near the point of augmentation (a point of water injection into a model cell; fig. 19) is likely overestimated but may be expected to rapidly decline as it is converted to streamflow within the existing channel. A cone of depression that forms around the group of added remedial wells covers most of the plume shell.
Table 15. Well-pumping rates in southeastern Nassau County, New York, under scenario 2.

[Pumping rates are listed in gallons per minute; screen top and bottom elevations in feet above the North American Vertical Datum of 1988; coordinate locations in State plane feet relative to the North American Datum of 1927]

\begin{tabular}{|c|c|c|c|c|c|}
\hline \multirow{2}{*}{$\begin{array}{c}\text { Remedial } \\
\text { well } \\
\text { number }\end{array}$} & \multirow[b]{2}{*}{$x$} & \multirow[b]{2}{*}{$\mathbf{Y}$} & \multirow[b]{2}{*}{ Rate } & \multicolumn{2}{|c|}{ Elevation } \\
\hline & & & & $\begin{array}{c}\text { Screen } \\
\text { top }\end{array}$ & $\begin{array}{l}\text { Screen } \\
\text { bottom }\end{array}$ \\
\hline \multicolumn{6}{|c|}{ Scenario $2 \mathrm{~A}$} \\
\hline dechc2 & $2,138,673$ & 179,544 & 750 & -500 & -700 \\
\hline dechc3 & $2,140,833$ & 178,412 & 750 & -500 & -700 \\
\hline dechc4 & $2,142,529$ & 175,947 & 750 & -500 & -700 \\
\hline dechc5 & $2,141,680$ & 172,017 & 600 & -700 & -850 \\
\hline deche6 & $2,138,367$ & 187,797 & 400 & -500 & -730 \\
\hline dechc7 & $2,140,313$ & 173,865 & 900 & -100 & -200 \\
\hline deche 8 & $2,140,170$ & 175,358 & 500 & -100 & -200 \\
\hline dechc9 & $2,143,119$ & 173,824 & 700 & -100 & -200 \\
\hline dechc10 & $2,144,119$ & 174,697 & 500 & -100 & -200 \\
\hline dechc11 & $2,145,072$ & 174,922 & 500 & -100 & -200 \\
\hline dechc12 & $2,146,552$ & 177,170 & 500 & -100 & -200 \\
\hline deche13 & $2,145,529$ & 177,122 & 500 & -100 & -200 \\
\hline deche14 & $2,147,316$ & 180,332 & 1,000 & -200 & -300 \\
\hline dechc15 & $2,146,145$ & 180,760 & 1,000 & -200 & -300 \\
\hline dechc16 & $2,145,060$ & 181,678 & 500 & -200 & -300 \\
\hline deche 17 & $2,143,743$ & 181,976 & 500 & -200 & -300 \\
\hline Total & & & 10,350 & & \\
\hline \multicolumn{6}{|c|}{ Scenario 2B } \\
\hline dechc2 & $2,138,673$ & 179,544 & 750 & -500 & -700 \\
\hline dechc3 & $2,140,833$ & 178,412 & 750 & -500 & -700 \\
\hline deche4 & $2,142,529$ & 175,947 & 750 & -500 & -700 \\
\hline dechc5 & $2,141,680$ & 172,017 & 600 & -700 & -850 \\
\hline dechc6 & $2,138,367$ & 187,797 & 400 & -500 & -730 \\
\hline dechc7 & $2,140,313$ & 173,865 & 700 & -100 & -200 \\
\hline dechc8 & $2,140,170$ & 175,358 & 500 & -100 & -200 \\
\hline dechc9 & $2,143,119$ & 173,824 & 700 & -100 & -200 \\
\hline dechc10 & $2,144,119$ & 174,697 & 500 & -100 & -200 \\
\hline deche11 & $2,145,072$ & 174,922 & 500 & -100 & -200 \\
\hline dechc12 & $2,146,552$ & 177,170 & 500 & -100 & -200 \\
\hline dechc13 & $2,145,529$ & 177,122 & 500 & -100 & -200 \\
\hline dechc14 & $2,147,316$ & 180,332 & 500 & -200 & -300 \\
\hline deche 15 & $2,146,145$ & 180,760 & 500 & -200 & -300 \\
\hline dechc16 & $2,145,060$ & 181,678 & 500 & -200 & -300 \\
\hline dechc17 & $2,143,743$ & 181,976 & 500 & -200 & -300 \\
\hline Total & & & 9,150 & & \\
\hline
\end{tabular}




\section{A. Scenario 2A}

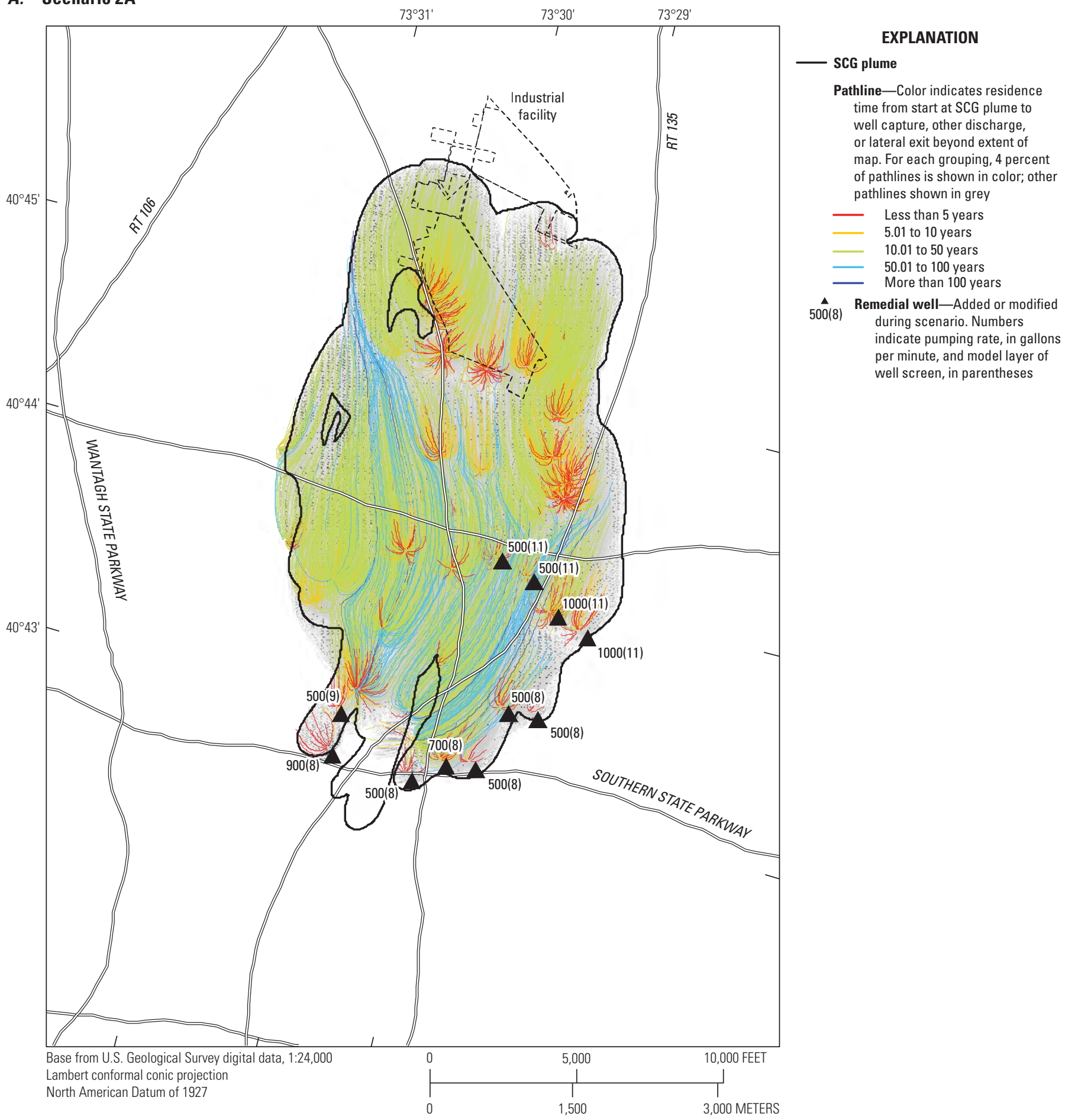

Figure 18. Maps showing remedial pumping wells, layers 6 through 15 of the New York State Department of Environmental Conservation (NYSEDC) standards, criteria, and guidance (SCG) plume shell (HDR, 2019) and particle pathlines started at the plume shell for $A$, scenario 2A, and $B$, scenario 2B, southeastern Nassau County, New York. A high-resolution version of this figure is available for download at https://doi.org/10.3133/sir20205090. 


\section{B. Scenario 2B}

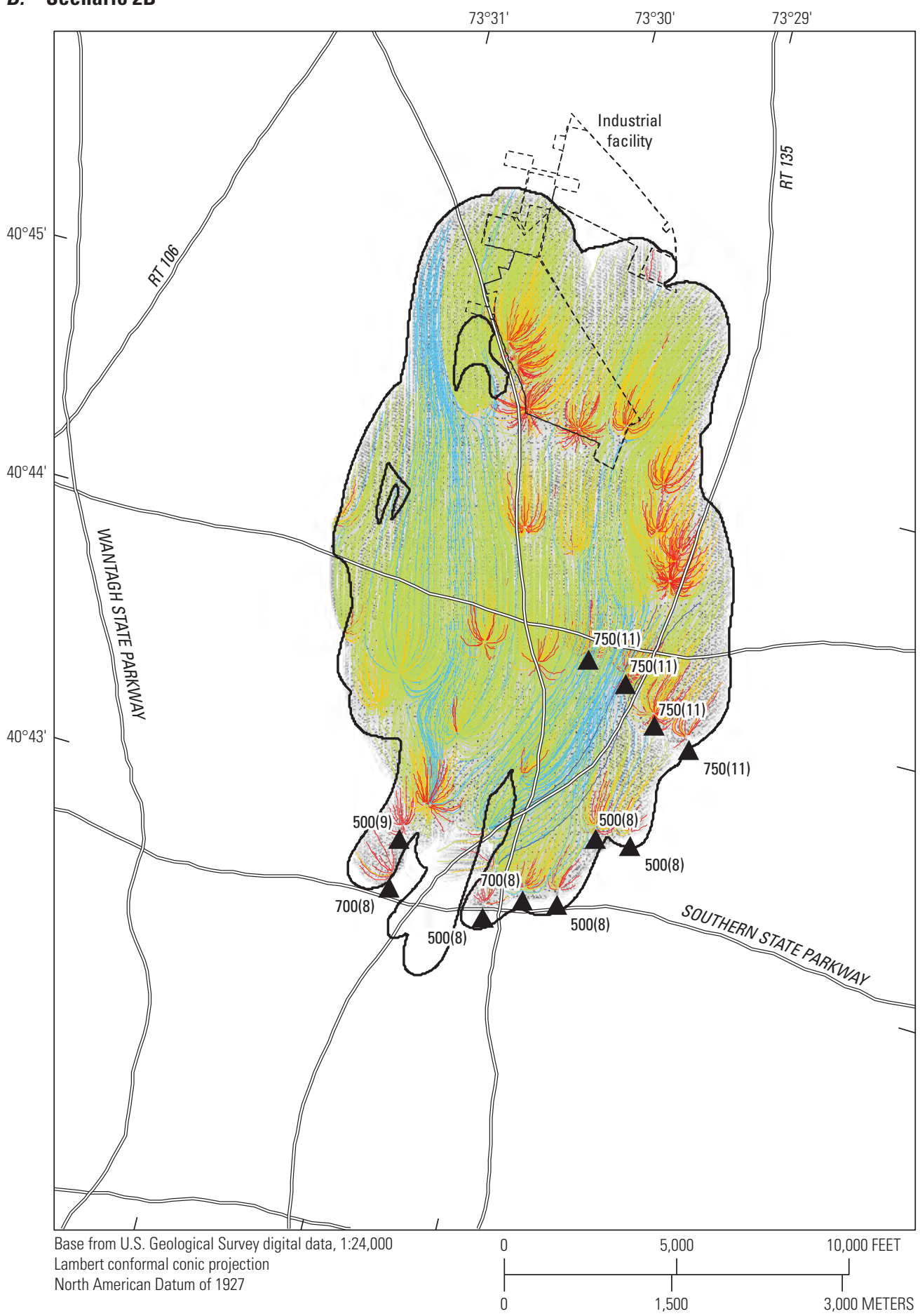

EXPLANATION

\section{— SCG plume}

Pathline-Color indicates residence time from start at SCG plume to well capture, other discharge, or lateral exit beyond extent of map. For each grouping, 4 percent of pathlines is shown in color; other pathlines shown in grey

Less than 5 years 5.01 to 10 years 10.01 to 50 years

50.01 to 100 years More than 100 years

- Remedial well—Added or modified during scenario. Numbers indicate pumping rate, in gallons per minute, and model layer of well screen, in parentheses

Figure 18. - Continued 


\section{A. Scenario 2A}

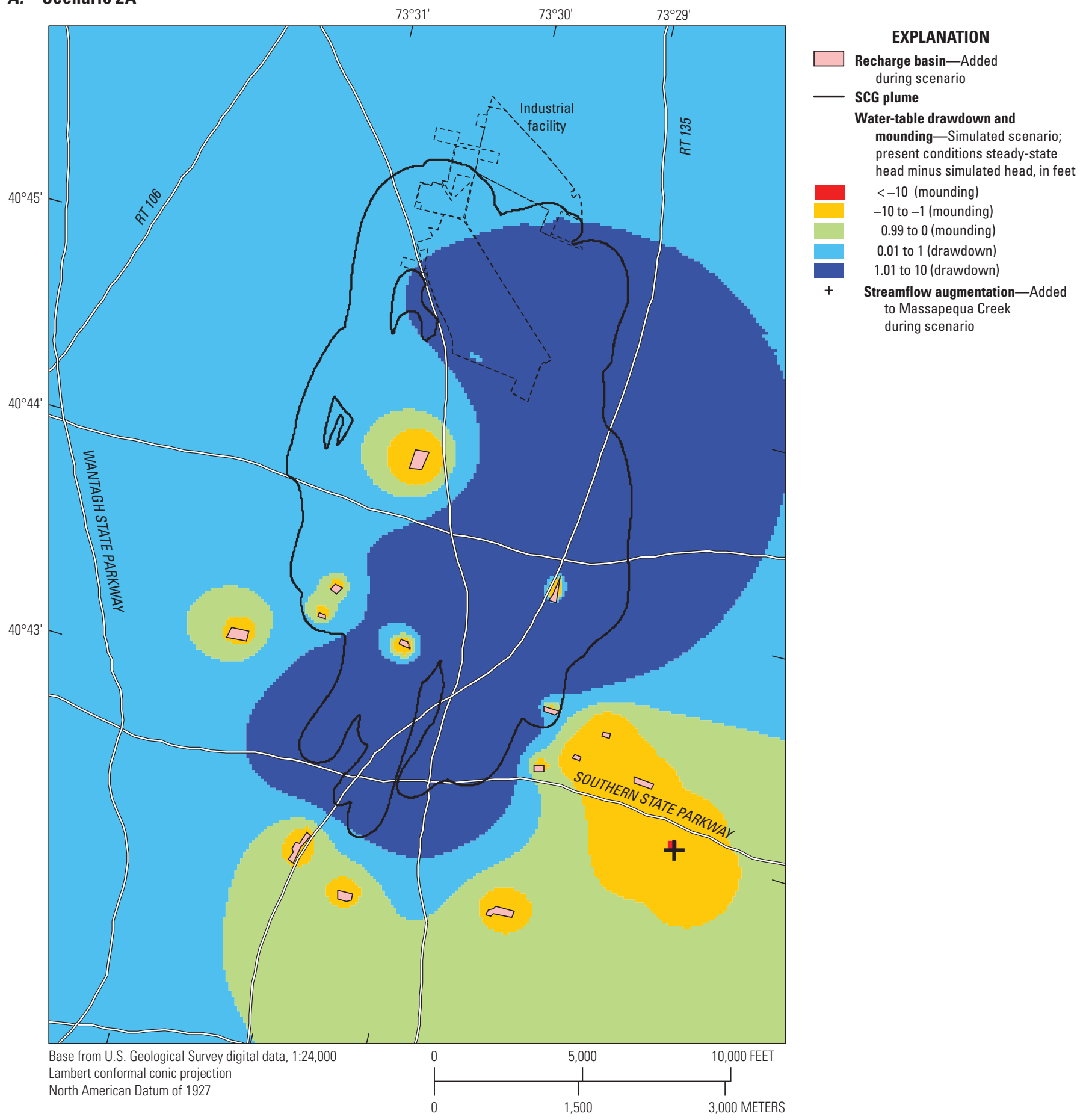

Figure 19. Maps showing locations of treated water return and simulated water-table change in scenarios $A, 2 \mathrm{~A}$ and $B, 2 \mathrm{~B}$, southeastern Nassau County, New York. SCG, New York State Department of Environmental Conservation (NYSEDC) standards, criteria, and guidance; $<$, less than. 


\section{B. Scenario 2B}

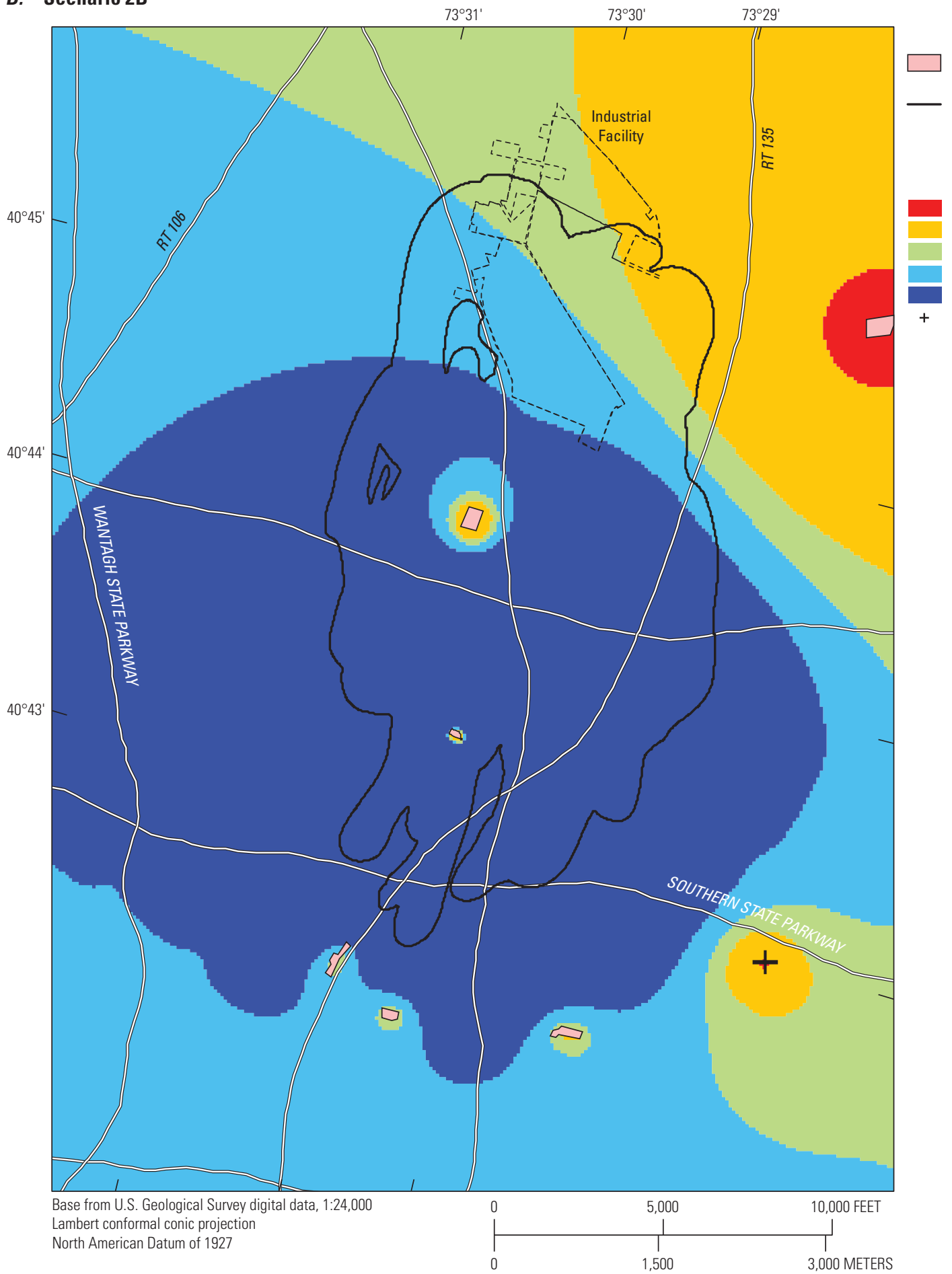

\section{EXPLANATION}

Recharge basin-Added during scenario

\section{SCG plume}

Water-table drawdown and mounding-Simulated scenario; present conditions steady-state head minus simulated head, in feet

$<-10$ (mounding)

-10 to -1 (mounding)

0.99 to 0 (mounding)

0.01 to 1 (drawdown)

1.01 to 10 (drawdown)

Streamflow augmentation-Added to Massapequa Creek during scenario

Figure 19. -Continued 


\section{Scenario 3}

The purpose of remedial scenarios $3 \mathrm{~A}$ and $3 \mathrm{~B}$ is to hydraulically contain TCVOC above $50 \mathrm{ppb}$ with a minimum of pumpage. Scenario $3 \mathrm{~A}$ adds 17 wells to scenario 1 for a total of 33 wells, and scenario $3 \mathrm{~B}$ adds 16 wells to scenario 1 for a total of 32 wells (table 16). Scenario 3A returns $16,127 \mathrm{gal} / \mathrm{min}$ to the land surface by using distributedrecharge basins. Scenario 3B implements a central recharge basin that handles $6,215 \mathrm{gal} / \mathrm{min}$ or about 1 percent of the total volume of water treated (table 10), with 7,962 gal/min placed in distributed recharge basins in the same configuration as in scenario 1 . Some remedial-well pumping rates near the eastern edge of the plume were slightly reduced from scenario $3 \mathrm{~A}$ to scenario $3 \mathrm{~B}$ to counterbalance the effects of the centralized recharge basin (fig. 20).

During both scenario 3 simulations, all particles started within the plume are captured by remedial or public-supply wells north of Southern State Parkway (fig. 21). Compared with scenarios 1 and 2, pathlines are significantly shorter in length and duration because of the smaller volume, and therefore the smaller number of associated starting points, of the 50-ppb plume than of an SCG plume. Particles with short travel times are generally captured by nearby remedial wells (red pathline color; fig. 20); however, some particles escape the plume shell to be captured by public-supply wells near the Southern State Parkway. There is also a small, separate area of plume (TCVOC greater than $50 \mathrm{ppb}$ ) within the middle Magothy aquifer and public-supply-well capture zones, and associated pathlines exhibit parabolic trajectories to wells N8664, N8665 (table 3). Compared with scenario 3A, additional particles escape the plume shell during scenario $3 \mathrm{~B}$ to be captured by public-supply wells near the Southern State Parkway. Additional illustrations of particle pathlines are given in Misut (2020).

Environmental effects (fig. 21; tables 12 and 13) during scenario 3 include groundwater mounding beneath recharge basins, cones of depression near pumping stresses, and changes in discharge to creeks. During scenario 3A, maximum water-table mounding of $12.6 \mathrm{ft}$ occurs near a group of recharge basins to the east of the facility (fig. $21 B$ ), and a cone of depression forms around the group of added remedial wells, which cover most of the plume shell. At the water table, mounds associated with recharge basins are interspersed within the cone of depression. During scenario 3B, simulated maximum water-table mounding increases to $59.8 \mathrm{ft}$ near the central recharge basin. The present depth to water at the hypothetical central-basin site is about $70 \mathrm{ft}$ (fig. 13). The central recharge basin is within the Bethpage State Park in a thick unsaturated zone that may accommodate greater mounding than near the leading edge of the plume, where the unsaturated zone is relatively thin. The size of the cone of depression that forms around the group of remedial wells increases (fig. 21A) and acquires a more circular shape (fig. 21B).
Table 16. Well-pumping rates in southeastern Nassau County, New York, under scenarios 3A and 3B.

[Pumping rates are listed in gallons per minute; elevations in feet above the North American Vertical Datum of 1988; coordinate locations in State plane feet relative to the North American Datum of 1927]

\begin{tabular}{|c|c|c|c|c|c|}
\hline \multirow{2}{*}{$\begin{array}{c}\text { Remedial } \\
\text { well } \\
\text { number }\end{array}$} & \multirow[b]{2}{*}{$x$} & \multirow[b]{2}{*}{$\mathbf{Y}$} & \multirow[b]{2}{*}{ Rate } & \multicolumn{2}{|c|}{ Elevation } \\
\hline & & & & Screen top & $\begin{array}{l}\text { Screen } \\
\text { bottom }\end{array}$ \\
\hline \multicolumn{6}{|c|}{ Scenario 3A } \\
\hline ex9 & $2,138,664$ & 181,102 & 250 & -50 & -250 \\
\hline ex11 & $2,141,901$ & 178,206 & 350 & -600 & -650 \\
\hline ex12 & $2,143,690$ & 184,027 & 700 & -200 & -300 \\
\hline ex13 & $2,144,811$ & 183,581 & 700 & -200 & -325 \\
\hline ex14 & $2,146,587$ & 182,721 & 1,000 & -300 & -400 \\
\hline ex15 & $2,140,218$ & 174,509 & 700 & -250 & -350 \\
\hline ex10a & $2,140,595$ & 178,121 & 250 & -100 & -200 \\
\hline ex10b & $2,140,765$ & 178,007 & 150 & -650 & -700 \\
\hline ex1 & $2,139,667$ & 182,930 & 400 & -350 & -450 \\
\hline ex2 & $2,140,776$ & 182,971 & 1,000 & -250 & -500 \\
\hline ex 4 & $2,140,031$ & 185,861 & 800 & -350 & -500 \\
\hline ex3 & $2,142,028$ & 182,872 & 440 & -350 & -575 \\
\hline ex 5 & $2,141,334$ & 185,892 & 400 & -400 & -550 \\
\hline ex6 & $2,143,724$ & 188,762 & 400 & -250 & -400 \\
\hline ex7 & $2,143,710$ & 189,783 & 500 & -200 & -350 \\
\hline ex8 & $2,143,007$ & 191,085 & 350 & -50 & -250 \\
\hline ex16 & $2,143,270$ & 185,785 & 700 & -450 & -600 \\
\hline \multicolumn{6}{|c|}{9,090} \\
\hline \multicolumn{6}{|c|}{ Scenario 3B } \\
\hline ex9 & $2,138,664$ & 181,102 & 250 & -50 & -250 \\
\hline ex11 & $2,141,901$ & 178,206 & 150 & -600 & -650 \\
\hline ex12 & $2,143,690$ & 184,027 & 300 & -200 & -300 \\
\hline ex13 & $2,144,684$ & 183,686 & 300 & -200 & -300 \\
\hline ex14 & $2,146,587$ & 182,721 & 700 & -200 & -300 \\
\hline ex15 & $2,140,218$ & 174,509 & 750 & -250 & -350 \\
\hline ex10a & $2,140,595$ & 178,121 & 250 & -100 & -200 \\
\hline ex10b & $2,140,765$ & 178,007 & 150 & -650 & -700 \\
\hline ex1 & $2,139,667$ & 182,930 & 400 & -350 & -450 \\
\hline ex2 & $2,140,776$ & 182,971 & 1,000 & -250 & -500 \\
\hline ex4 & $2,142,028$ & 182,872 & 800 & -350 & -575 \\
\hline ex3 & $2,140,031$ & 185,861 & 440 & -350 & -500 \\
\hline ex 5 & $2,141,334$ & 185,892 & 400 & -400 & -550 \\
\hline ex6 & $2,143,724$ & 188,762 & 400 & -250 & -400 \\
\hline ex7 & $2,143,710$ & 189,783 & 500 & -200 & -350 \\
\hline ex8 & $2,143,007$ & 191,085 & 350 & -50 & -250 \\
\hline Total & & & 7,140 & & \\
\hline
\end{tabular}




\section{A. Scenario 3A}

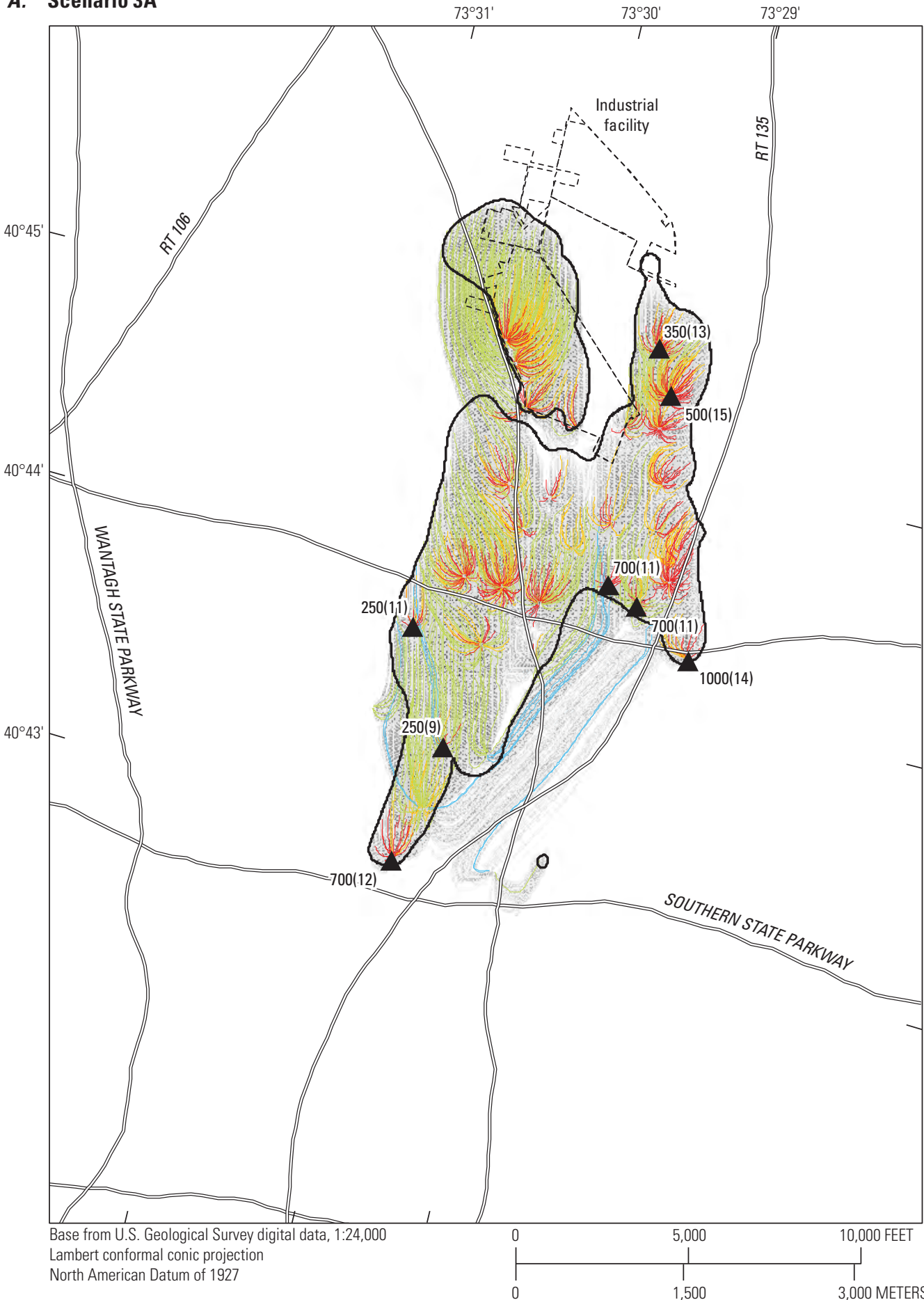

EXPLANATION

TCVOC 50-ppb plume

Pathline-Color indicates residence time from start at SCG plume to well capture, other discharge, or lateral exit beyond extent of map. For each grouping, 4 percent of pathlines is shown in color; other pathlines shown in grey

Less than 5 years 5.01 to 10 years 10.01 to 50 years 50.01 to 100 years More than 100 years

$400(8)$ Remedial well-Added or modified during scenario. Numbers indicate pumping rate, in gallons per minute and model layer of well screen, in parentheses

Figure 20. Maps showing scenarios $A, 3 A$ and $B, 3 B$, pumping wells, the total chlorinated volatile organic compound (TCVOC) greater than (>) 50-part-per-billion (ppb) plume shell (HDR, 2019), and particle pathlines started at the plume shell, southeastern Nassau County, New York. A high-resolution version of this figure is available for download at https://doi.org/10.3133/sir20205090. 


\section{B. Scenario 3B}

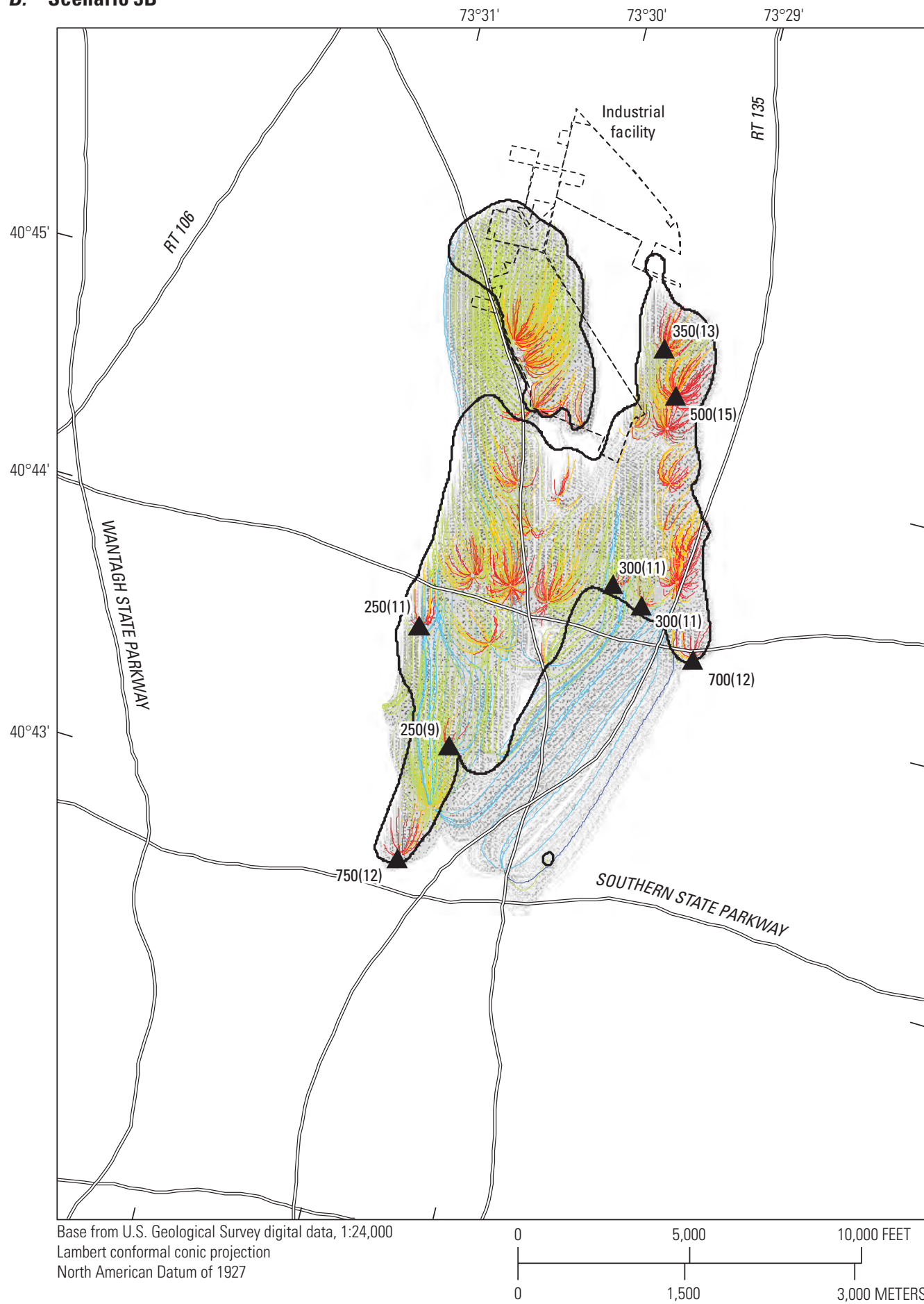

\section{EXPLANATION}

TCVOC 50-ppb plume

Pathline-Color indicates residence time from start at SCG plume to well capture, other discharge, or lateral exit beyond extent of map. For each grouping, 4 percent of pathlines is shown in color; other pathlines shown in grey

Less than 5 years 5.01 to 10 years 10.01 to 50 years 50.01 to 100 years More than 100 years

400(8) Remedial well—Added or modified during scenario. Numbers indicate pumping rate, in gallons per minute and model layer of well screen, in parentheses

Figure 20. - Continued 


\section{A. Scenario $3 \mathrm{~A}$}

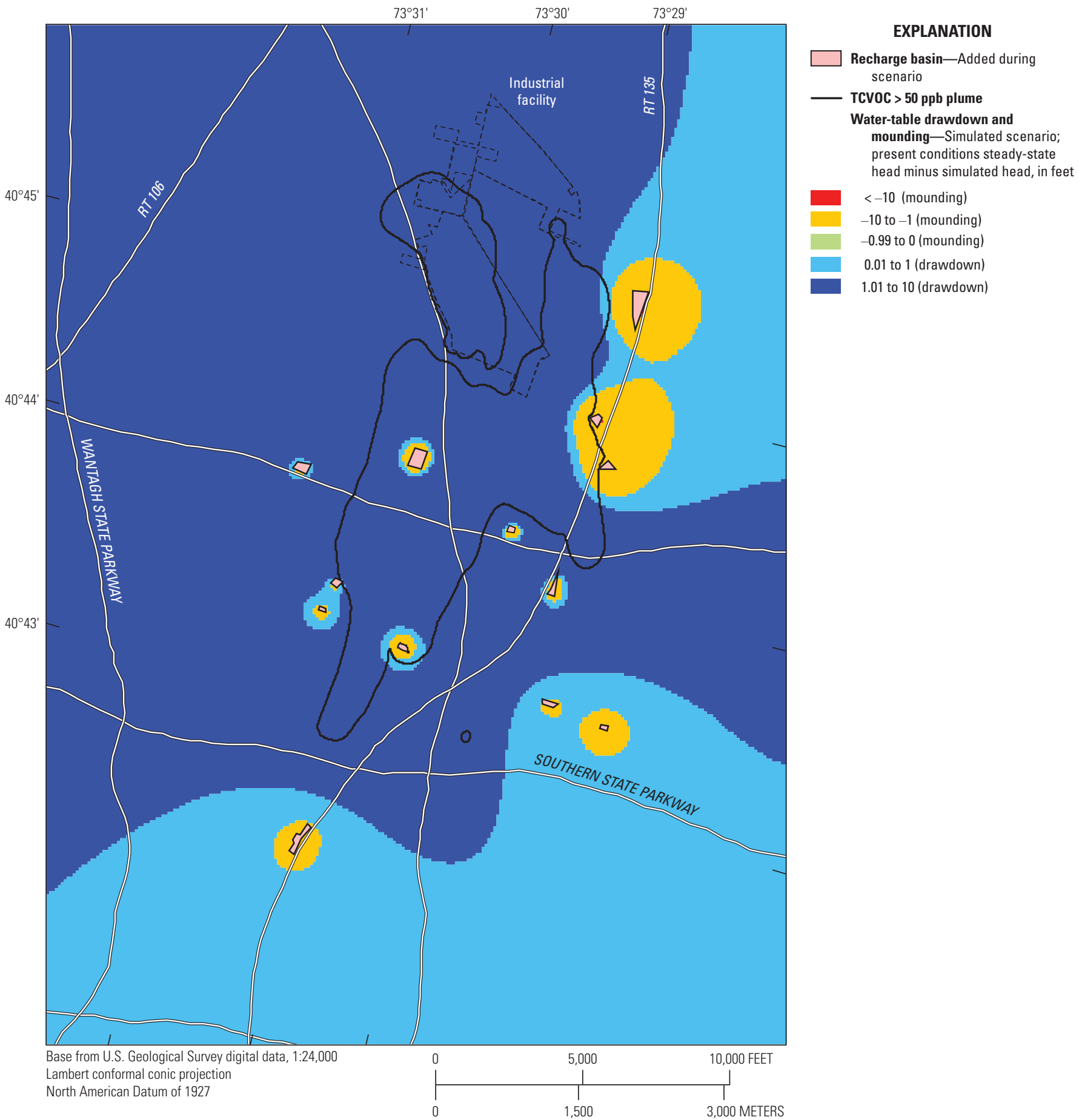

Figure 21. Maps showing locations in scenarios $A, 3 A$ and $B, 3 B$ of treated-water return and simulated water-table change from scenario 1, southeastern Nassau County, New York. TCVOC, total chlorinated volatile organic compound; ppb, part per billion; $>$, greater than; $<$, less than 


\section{B. Scenario 3B}

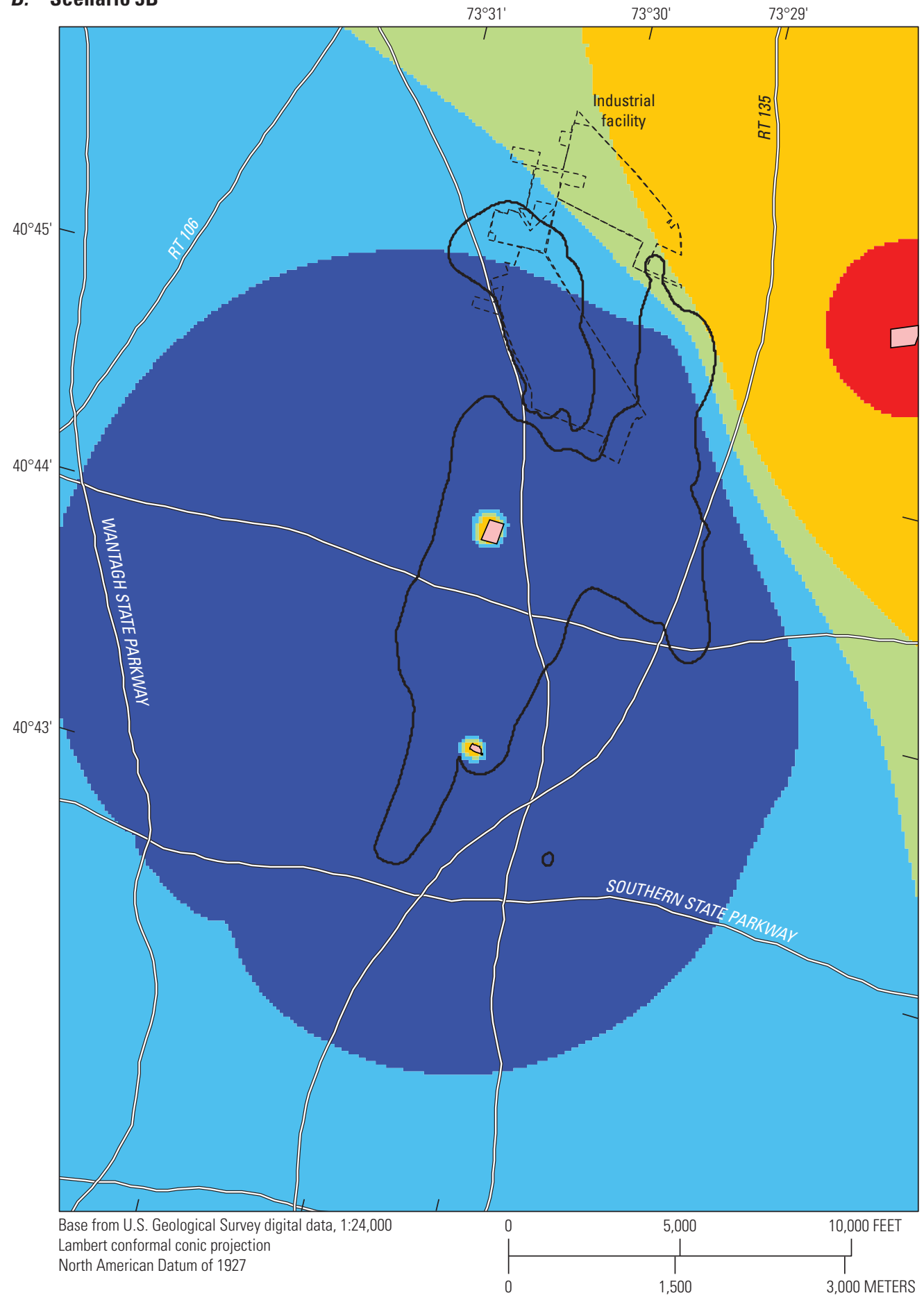

\section{EXPLANATION}

Recharge basin—Added during scenario

TCVOC $>50 \mathrm{ppb}$ plume Water-table drawdown and mounding - Simulated scenario; present conditions steady-state head minus simulated head, in feet

$<-10$ (mounding)

-10 to -1 (mounding) -0.99 to 0 (mounding) 0.01 to 1 (drawdown) 1.01 to 10 (drawdown)

Figure 21. - Continued 


\section{Scenario 4}

The purpose of remedial scenario 4 is to hydraulically contain TCVOC above $100 \mathrm{ppb}$ with a minimum of pumpage and to return water through a combination of distributedrecharge basins and injection wells paired with and generally upgradient from the remedial wells by several hundred feet. Scenario 4 adds 25 wells to scenario 1 for a total of 41 wells and $17,587 \mathrm{gal} / \mathrm{min}$ total pumpage (table 17$)$. Of this total, $8,016 \mathrm{gal} / \mathrm{min}$ or 46 percent is placed in distributed recharge basins in the same configuration as in scenario 1 . The remainder of $9,571 \mathrm{gal} / \mathrm{min}$ is injected.

During the scenario 4 simulation, all particles started within the plume are captured by remedial or public-supply wells north of Southern State Parkway (fig. 22). Compared with the pathlines in other scenarios, these pathlines are significantly shorter in length and duration caused by the smaller volume of the 100-ppb plume as compared to other plumes and therefore a more limited number of associated starting points. Particles are generally captured by nearby remedial wells and have short travel times (red pathline color; fig. 22); however, some pathlines escape the plume shell to be captured by public-supply wells near the Southern State Parkway. Additional illustrations of particle pathlines are given in Misut (2020).

Environmental effects (fig. 23; tables 12 and 13) during scenario 4 include groundwater mounding near points of injection and recharge basins, changes in discharge to creeks, discharge to coasts, and subsea- discharge boundaries associated with freshwater/saltwater interfaces. During scenario 4, maximum water-table mounding of $8.8 \mathrm{ft}$ occurs near injection-well pairs and the RE108 recharge basin. Slight changes in net total shoreline or subsea discharge amounts (table 13) are less than what might be accurately simulated given the numericalmodel convergence criteria.

\section{Scenario 5}

The purpose of remedial scenarios 5A and 5B (table 18) is to hydraulically contain all contaminants above SCG standards by targeting high-concentration parts of the plume, as was done in scenario 3 . These scenarios add 24 wells to scenario 1 for a total of 40 wells. Scenario 5 A returns $1,500 \mathrm{gal} / \mathrm{min}$ of treated water as augmentation of streamflow at Massapequa Creek and $18,931 \mathrm{gal} / \mathrm{min}$ to the land surface by using distributed recharge basins. Scenario 5B implements a centralized recharge basin that handles $7,215 \mathrm{gal} / \mathrm{min}$, or about 37 percent of total water treated (table 10), with $17,177 \mathrm{gal} / \mathrm{min}$ placed in distributed-recharge basin flows and $2,000 \mathrm{gal} / \mathrm{min}$ of streamflow augmentation. To optimize remedial design, some remedial-well pumping rates near the eastern edge of the plume are slightly reduced from scenario 5A to scenario 5B (fig. 24).

During both scenario 5 simulations, all particles started within the SCG plume are captured by remedial or publicsupply wells within the plume footprint (fig. 24). In contrast with scenario 2, the lengths and durations of pathlines started in the upper zone of the plume are reduced in the central and southern parts of the plume during scenario 5A. During scenario $5 \mathrm{~B}$, some pathlines take a more east-to-west trajectory as compared to those of scenario 5A (fig. 24).

Environmental effects (fig. 25; tables 12 and 13) during scenario 5 include groundwater mounding beneath recharge basins, cones of depression near pumping stresses, and changes in discharge to creeks. During scenario 5A, maximum water-table mounding of $14.3 \mathrm{ft}$ occurs near the point of streamflow augmentation. Due to simplified boundary conditions representing groundwater/surface-water interactions, water-table mounding near the stream channel is likely overestimated but is realistically expected to rapidly decline as it is converted to streamflow within the existing channel. Mounding of about $11 \mathrm{ft}$ also occurs near a group of three recharge basins to the east of the industrial facility. A cone of depression is simulated that surrounds the group of added remedial wells and captures most of the plume shell. During scenario $5 \mathrm{~B}$, maximum water-table mounding increases to $66 \mathrm{ft}$ near the central recharge basin. The present-conditions depth to water at the central-basin site is about $70 \mathrm{ft}$ (fig. 13). The central recharge basin is within the Bethpage State Park in an area with a thick unsaturated zone that may accommodate greater mounding than near the leading edge of the plume, where the unsaturated zone is relatively thin. The size of the cone of depression that forms around the group of remedial wells increases and acquires a more circular shape, but with two interspersed mounds associated with recharge basins. To counterbalance the effects of the centralized recharge basin (fig. 25), remedial-well pumping rates are reduced near the eastern edge of the plume. 
Table 17. Well-pumping rates in southeastern Nassau County, New York, under scenario 4.

[Pumping and injection rates are listed in gallons per minute; elevations of screen tops and bottoms are in feet above the North American Vertical Datum of 1988; coordinate locations are in State plane feet relative to the North American Datum of 1927. Negative pumping values indicate injection]

\begin{tabular}{|c|c|c|c|c|c|}
\hline $\begin{array}{c}\text { Remedial } \\
\text { well } \\
\text { number }\end{array}$ & $x$ & $\mathbf{Y}$ & Rate & $\begin{array}{c}\text { Screen } \\
\text { top }\end{array}$ & $\begin{array}{l}\text { Screen } \\
\text { bottom }\end{array}$ \\
\hline ae & $2,143,052$ & 191,157 & 530 & -40 & -220 \\
\hline ai2 & $2,142,051$ & 191,894 & -265 & 55 & -320 \\
\hline ail & $2,143,519$ & 192,250 & -265 & 55 & -320 \\
\hline be & $2,143,760$ & 189,943 & 490 & -165 & -335 \\
\hline bil & $2,144,400$ & 191,285 & -245 & -80 & -420 \\
\hline bi2 & $2,142,471$ & 190,593 & -245 & -80 & -420 \\
\hline ce & $2,143,659$ & 188,679 & 400 & -240 & -380 \\
\hline cil & $2,144,233$ & 189,691 & -200 & -170 & -450 \\
\hline de & $2,144,518$ & 187,491 & 290 & -380 & -480 \\
\hline ci2 & $2,142,764$ & 189,440 & -200 & -170 & -450 \\
\hline dil & $2,144,589$ & 188,936 & -145 & -335 & -535 \\
\hline ee & $2,144,619$ & 186,151 & 240 & -415 & -500 \\
\hline di2 & $2,142,659$ & 188,391 & -145 & -335 & -535 \\
\hline eil & $2,144,757$ & 187,804 & -120 & -375 & -540 \\
\hline ei2 & $2,143,226$ & 186,797 & -120 & -375 & -540 \\
\hline fe & $2,145,074$ & 185,241 & 200 & -510 & -580 \\
\hline fil & $2,145,176$ & 186,797 & -100 & -475 & -615 \\
\hline fi2 & $2,143,813$ & 185,958 & -100 & -475 & -615 \\
\hline ge & $2,145,378$ & 184,331 & 120 & -275 & -315 \\
\hline gi1 & $2,145,596$ & 185,580 & -60 & -250 & -340 \\
\hline gi2 & $2,143,750$ & 184,972 & -60 & -250 & -340 \\
\hline he & $2,146,313$ & 183,042 & 150 & -170 & -185 \\
\hline hi1 & $2,146,078$ & 184,238 & -75 & -165 & -195 \\
\hline hi2 & $2,145,449$ & 183,986 & -75 & -165 & -195 \\
\hline ie & $2,139,917$ & 185,696 & 460 & -340 & -500 \\
\hline ii1 & $2,139,828$ & 187,321 & -230 & -260 & -580 \\
\hline ii2 & $2,138,339$ & 187,132 & -230 & -260 & -580 \\
\hline je & $2,141,510$ & 186,025 & 420 & -415 & -558 \\
\hline ji1 & $2,142,009$ & 187,007 & -210 & -340 & -630 \\
\hline ji2 & $2,140,646$ & 187,300 & -210 & -340 & -630 \\
\hline ke & $2,139,412$ & 182,915 & 270 & -360 & -455 \\
\hline ki1 & $2,139,429$ & 184,930 & -135 & -315 & -500 \\
\hline ki2 & $2,138,255$ & 185,056 & -135 & -315 & -500 \\
\hline le & $2,140,726$ & 182,764 & 1,000 & -240 & -700 \\
\hline
\end{tabular}

Table 17. Well-pumping rates in southeastern Nassau County, New York, under scenario 4.-Continued

[Pumping and injection rates are listed in gallons per minute; elevations of screen tops and bottoms are in feet above the North American Vertical Datum of 1988; coordinate locations are in State plane feet relative to the North American Datum of 1927. Negative pumping values indicate injection]

\begin{tabular}{|c|c|c|c|c|c|}
\hline $\begin{array}{c}\text { Remedial } \\
\text { well } \\
\text { number }\end{array}$ & $x$ & $\mathbf{Y}$ & Rate & $\begin{array}{l}\text { Screen } \\
\text { top }\end{array}$ & $\begin{array}{l}\text { Screen } \\
\text { bottom }\end{array}$ \\
\hline li1 & $2,141,233$ & 184,888 & -500 & -100 & -650 \\
\hline li2 & $2,140,268$ & 184,783 & -500 & -100 & -650 \\
\hline me & $2,141,889$ & 182,840 & 1,000 & -350 & -700 \\
\hline mil & $2,143,058$ & 184,783 & -500 & -235 & -690 \\
\hline $\mathrm{mi} 2$ & $2,142,198$ & 184,825 & -500 & -235 & -690 \\
\hline ne & $2,138,805$ & 181,399 & 50 & -220 & -235 \\
\hline nil & $2,138,926$ & 182,119 & -25 & -215 & -240 \\
\hline ni2 & $2,138,548$ & 182,119 & -25 & -215 & -240 \\
\hline oe & $2,140,145$ & 180,564 & 200 & -455 & -480 \\
\hline oil & $2,140,184$ & 182,015 & -100 & -440 & -495 \\
\hline oi2 & $2,139,492$ & 181,973 & -100 & -440 & -495 \\
\hline pe & $2,141,030$ & 180,665 & 200 & -600 & -625 \\
\hline pil & $2,141,422$ & 182,077 & -100 & -585 & -640 \\
\hline pi2 & $2,140,751$ & 182,077 & -100 & -585 & -640 \\
\hline qe & $2,141,889$ & 180,665 & 300 & -600 & -640 \\
\hline qi1 & $2,142,743$ & 182,161 & -150 & -580 & -655 \\
\hline qi2 & $2,141,988$ & 182,161 & -150 & -580 & -655 \\
\hline re & $2,140,777$ & 178,567 & 50 & -145 & -160 \\
\hline ril & $2,141,737$ & 179,644 & -25 & -145 & -160 \\
\hline ri2 & $2,140,604$ & 179,770 & -25 & -145 & -160 \\
\hline $\mathrm{se}$ & $2,140,295$ & 175,261 & 500 & -115 & -125 \\
\hline sil & $2,140,960$ & 177,736 & -250 & -115 & -125 \\
\hline si2 & $2,139,849$ & 177,736 & -250 & -115 & -125 \\
\hline te & $2,142,565$ & 182,590 & 700 & -700 & -900 \\
\hline ti & $2,144,249$ & 184,326 & -700 & -650 & -800 \\
\hline ue & $2,144,828$ & 182,796 & 300 & -350 & -450 \\
\hline ui & $2,144,500$ & 184,068 & -300 & -350 & -450 \\
\hline ve & $2,145,919$ & 182,933 & 500 & -300 & -500 \\
\hline vi & $2,144,866$ & 183,766 & -500 & -200 & -400 \\
\hline we & $2,136,421$ & 192,363 & 300 & -250 & -350 \\
\hline wi1 & $2,136,707$ & 194,043 & -150 & -250 & -350 \\
\hline wi2 & $2,135,258$ & 193,770 & -150 & -250 & -350 \\
\hline Total & & & 0 & & \\
\hline
\end{tabular}




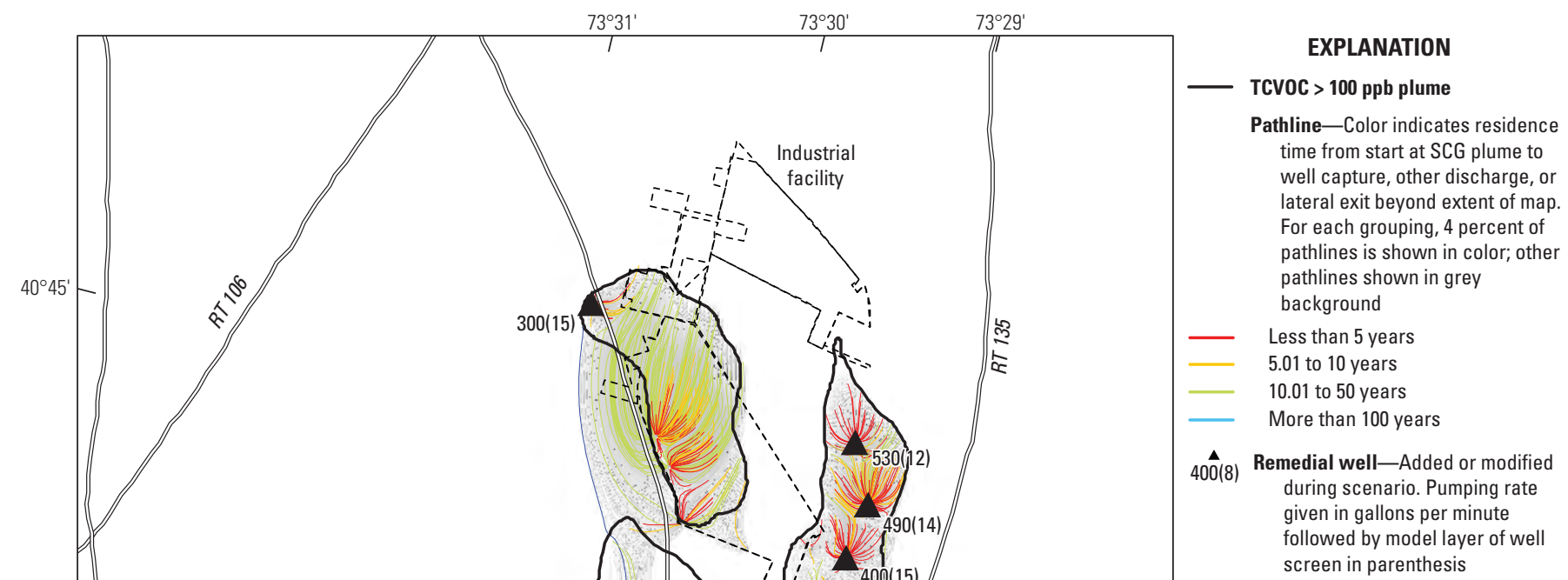

ollowed by model layer of well creen in parenthesis

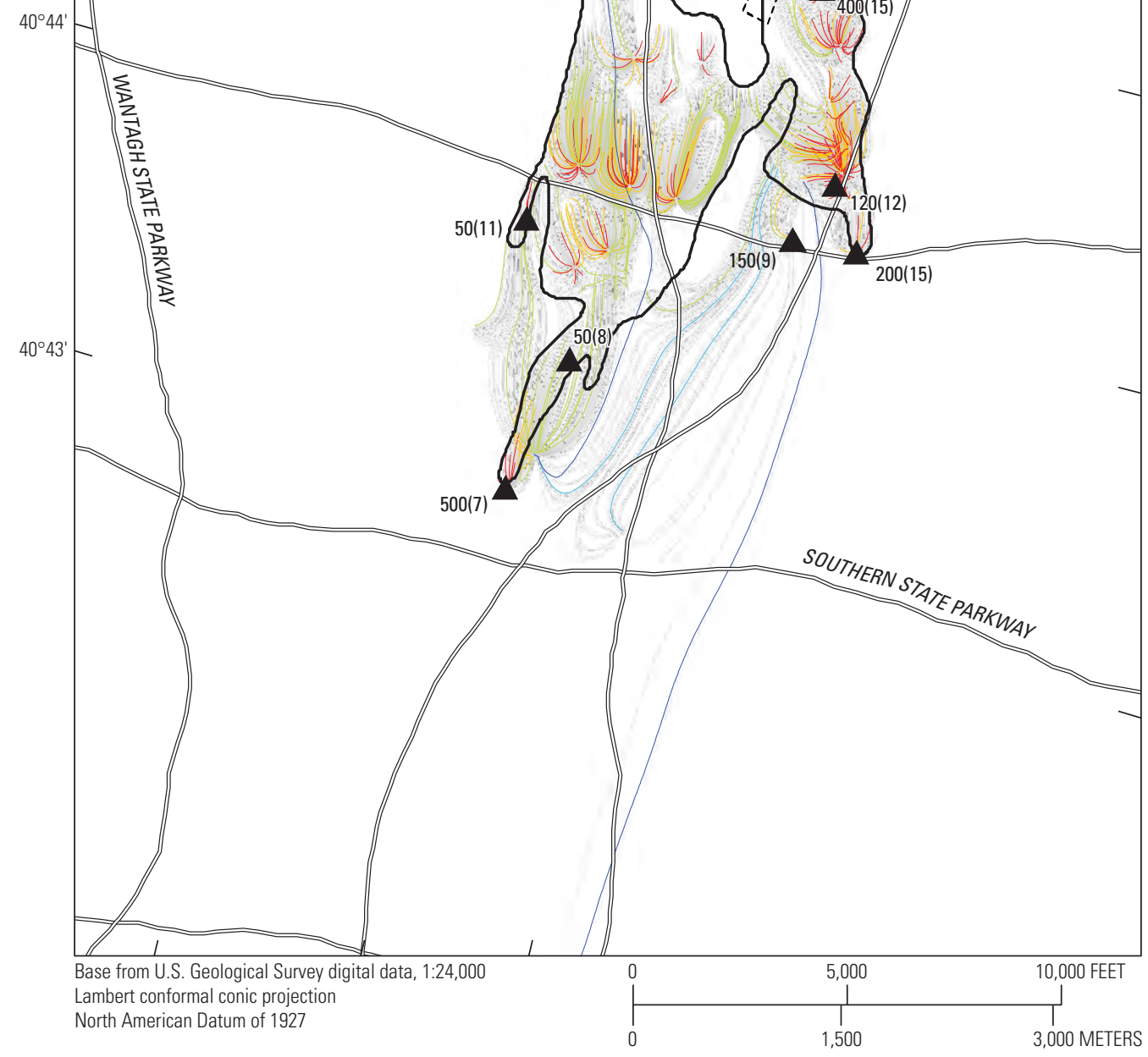

Figure 22. Map showing scenario 4 pumping wells, the total chlorinated volatile organic compound (TCVOC) greater than (>) 100-part-per-billion (ppb) plume shell (HDR, 2019), and particle pathlines starting at the plume shell, southeastern Nassau County, New York. A high-resolution version of this figure is available for download at https://doi.org/10.3133/sir20205090. 


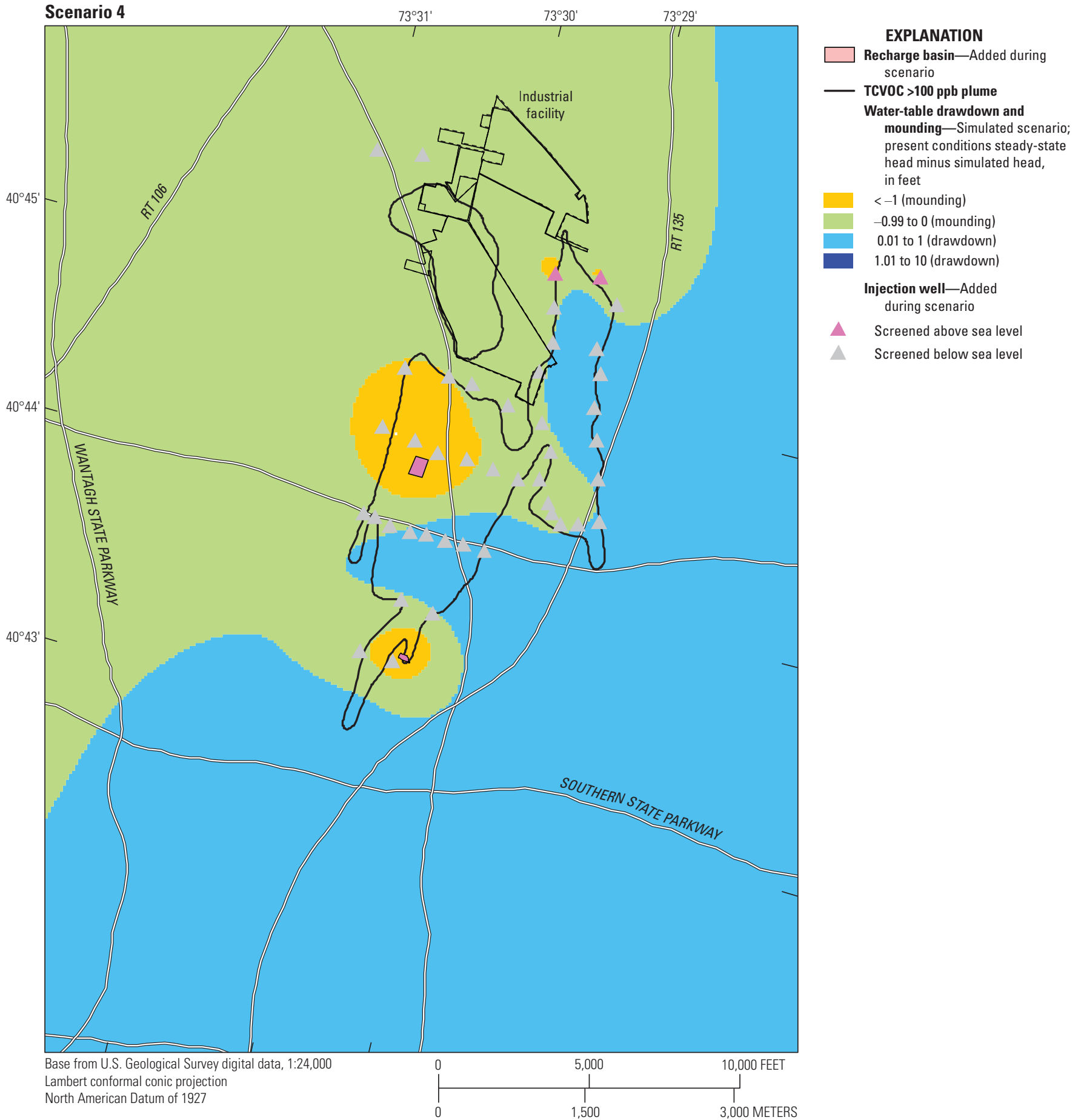

Figure 23. Map showing scenario 4 locations of treated-water return and simulated water-table change from scenario 1, southeastern Nassau County, New York. TCVOC, total chlorinated volatile organic compound; ppb, part per billion; >, greater than; <, less than. 
Table 18. Well-pumping rates in southeastern Nassau County, New York, under scenario 5.

[Pumping rates are in gallons per minute; elevations of screen tops and bottoms in feet above the North American Vertical Datum of 1988; coordinate locations in State plane feet relative to the North American Datum of 1927]

\begin{tabular}{|c|c|c|c|c|c|}
\hline \multirow{2}{*}{$\begin{array}{c}\text { Remedial } \\
\text { well } \\
\text { number }\end{array}$} & \multirow[b]{2}{*}{$x$} & \multirow[b]{2}{*}{$\mathbf{Y}$} & \multirow[b]{2}{*}{ Rate } & \multicolumn{2}{|c|}{ Elevation } \\
\hline & & & & $\begin{array}{c}\text { Screen } \\
\text { top }\end{array}$ & $\begin{array}{l}\text { Screen } \\
\text { bottom }\end{array}$ \\
\hline \multicolumn{6}{|c|}{ Scenario $5 \mathrm{~A}$} \\
\hline hc2 & $2,138,673$ & 179,544 & 750 & -500 & -700 \\
\hline hc3 & $2,140,833$ & 178,412 & 750 & -500 & -700 \\
\hline hc4 & $2,142,529$ & 175,947 & 750 & -500 & -700 \\
\hline hc5 & $2,141,680$ & 172,017 & 600 & -700 & -850 \\
\hline hc6 & $2,138,367$ & 187,797 & 400 & -500 & -730 \\
\hline hc7 & $2,140,313$ & 173,865 & 700 & -100 & -200 \\
\hline hc8 & $2,140,170$ & 175,358 & 500 & -100 & -200 \\
\hline hc9 & $2,143,119$ & 173,824 & 700 & -100 & -200 \\
\hline hc10 & $2,144,119$ & 174,697 & 500 & -100 & -200 \\
\hline hc11 & $2,145,072$ & 174,922 & 500 & -100 & -200 \\
\hline hc12 & $2,146,552$ & 177,170 & 500 & -100 & -200 \\
\hline hc13 & $2,145,529$ & 177,122 & 500 & -100 & -200 \\
\hline hc14 & $2,147,316$ & 180,332 & 800 & -200 & -300 \\
\hline hc15 & $2,146,167$ & 180,748 & 800 & -200 & -300 \\
\hline hc16 & $2,145,060$ & 181,678 & 150 & -200 & -300 \\
\hline hc17 & $2,143,743$ & 181,976 & 150 & -200 & -300 \\
\hline ex1 & $2,139,667$ & 182,930 & 400 & -350 & -450 \\
\hline ex2 & $2,140,776$ & 182,971 & 1,000 & -250 & -500 \\
\hline ex3 & $2,142,028$ & 182,872 & 800 & -350 & -575 \\
\hline ex4 & $2,140,031$ & 185,861 & 440 & -350 & -500 \\
\hline ex 5 & $2,141,334$ & 185,892 & 400 & -400 & -550 \\
\hline ex6 & $2,143,724$ & 188,762 & 400 & -250 & -400 \\
\hline ex7 & $2,143,710$ & 189,783 & 500 & -200 & -350 \\
\hline ex8 & $2,143,007$ & 191,085 & 350 & -50 & -250 \\
\hline Total & & & 13,340 & & \\
\hline
\end{tabular}

Table 18. Well-pumping rates in southeastern Nassau County, New York, under scenario 5.-Continued

[Pumping rates are in gallons per minute; elevations of screen tops and bottoms in feet above the North American Vertical Datum of 1988; coordinate locations in State plane feet relative to the North American Datum of 1927]

\begin{tabular}{|c|c|c|c|c|c|}
\hline \multirow{2}{*}{$\begin{array}{c}\text { Remedial } \\
\text { well } \\
\text { number }\end{array}$} & \multirow[b]{2}{*}{$x$} & \multirow[b]{2}{*}{$\mathbf{Y}$} & \multirow[b]{2}{*}{ Rate } & \multicolumn{2}{|c|}{ Elevation } \\
\hline & & & & $\begin{array}{c}\text { Screen } \\
\text { top }\end{array}$ & $\begin{array}{l}\text { Screen } \\
\text { bottom }\end{array}$ \\
\hline \multicolumn{6}{|c|}{ Scenario 5B } \\
\hline hc2 & $2,138,673$ & 179,544 & 750 & -500 & -700 \\
\hline hc3 & $2,140,833$ & 178,412 & 750 & -500 & -700 \\
\hline hc4 & $2,142,529$ & 175,947 & 750 & -500 & -700 \\
\hline hc5 & $2,141,680$ & 172,017 & 600 & -700 & -850 \\
\hline hc6 & $2,138,367$ & 187,797 & 400 & -500 & -730 \\
\hline he7 & $2,140,313$ & 173,865 & 700 & -100 & -200 \\
\hline hc 8 & $2,140,170$ & 175,358 & 500 & -100 & -200 \\
\hline hc9 & $2,143,119$ & 173,824 & 700 & -100 & -200 \\
\hline hc10 & $2,144,119$ & 174,697 & 500 & -100 & -200 \\
\hline hc11 & $2,145,072$ & 174,922 & 500 & -100 & -200 \\
\hline hc12 & $2,146,552$ & 177,170 & 500 & -100 & -200 \\
\hline hc13 & $2,145,529$ & 177,122 & 500 & -100 & -200 \\
\hline hc14 & $2,147,316$ & 180,332 & 250 & -200 & -300 \\
\hline hc15 & $2,146,145$ & 180,760 & 150 & -200 & -300 \\
\hline hc16 & $2,145,060$ & 181,678 & 150 & -200 & -300 \\
\hline hc17 & $2,143,743$ & 181,976 & 150 & -200 & -300 \\
\hline ex1 & $2,139,667$ & 182,930 & 400 & -350 & -450 \\
\hline ex2 & $2,140,776$ & 182,971 & 1,000 & -250 & -500 \\
\hline ex3 & $2,142,028$ & 182,872 & 800 & -350 & -575 \\
\hline ex4 & $2,140,031$ & 185,861 & 440 & -350 & -500 \\
\hline ex5 & $2,141,334$ & 185,892 & 400 & -400 & -550 \\
\hline ex6 & $2,143,724$ & 188,762 & 400 & -250 & -400 \\
\hline ex7 & $2,143,710$ & 189,783 & 500 & -200 & -350 \\
\hline ex8 & $2,143,007$ & 191,085 & 350 & -50 & -250 \\
\hline Total & & & 12,140 & & \\
\hline
\end{tabular}




\section{A. Scenario 5A}

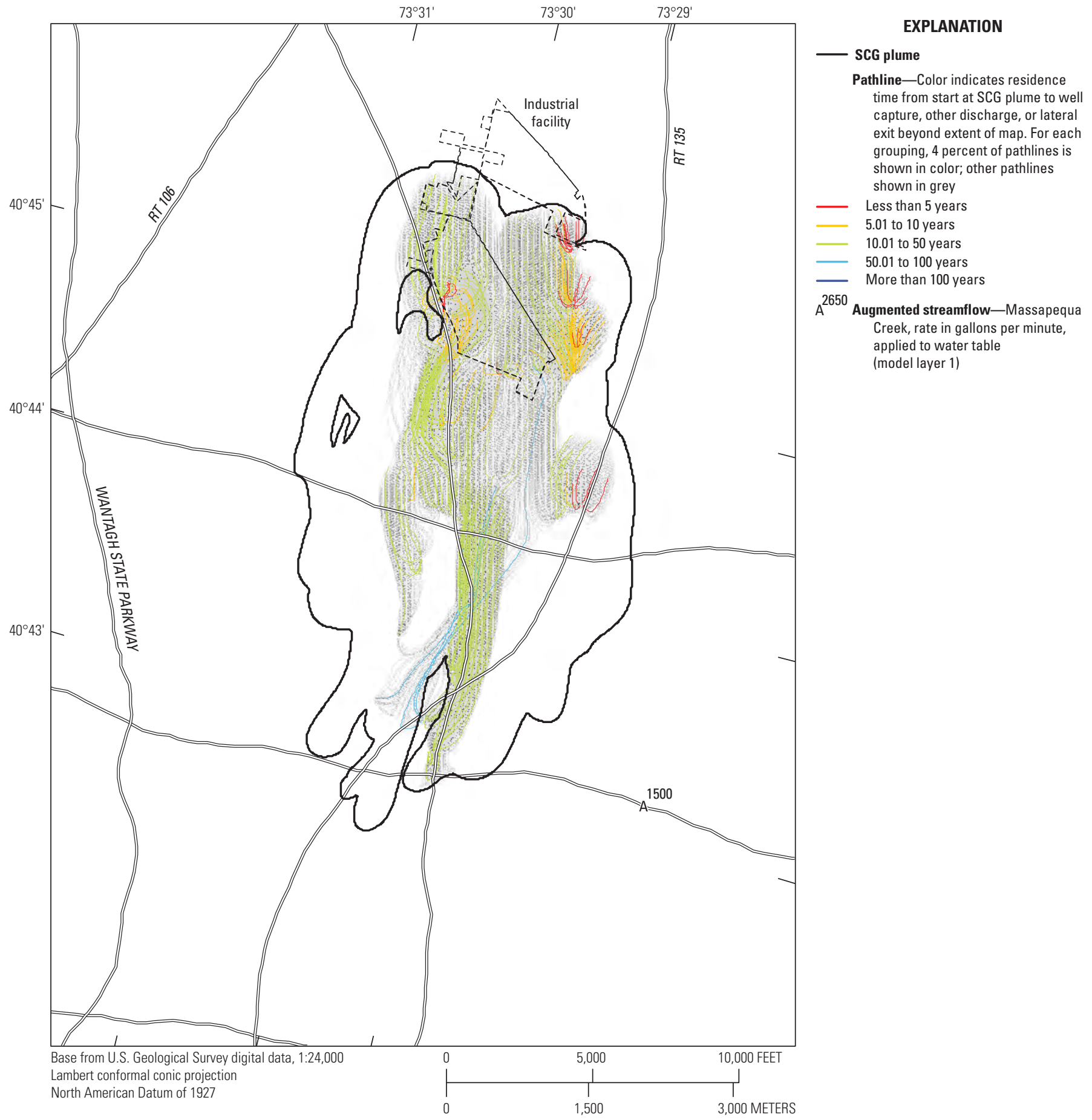

Figure 24. Maps showing remedial wells, the New York State Department of Environmental Conservation (NYSEDC) standards, criteria, and guidance (SCG) plume shell (HDR, 2019), and particle pathlines started at plume shell for scenarios 5A and 5B, southeastern Nassau County, New York; plume shell and particle pathlines for $A$, layers 1 to 5 for scenario $5 A$; $B$, layers 1 to 5 for scenario $5 B$; $C$, layers 6 to 15 for scenario $5 A$; $D$, layers 6 to 15 for scenario $5 B$; $E$, layers 16 to 23 for scenario $5 A$; and $F$, layers 16 to 23 for scenario $5 B$. A highresolution version of this figure is available for download at https://doi.org/10.3133/sir20205090. 


\section{B. Scenario 5B}

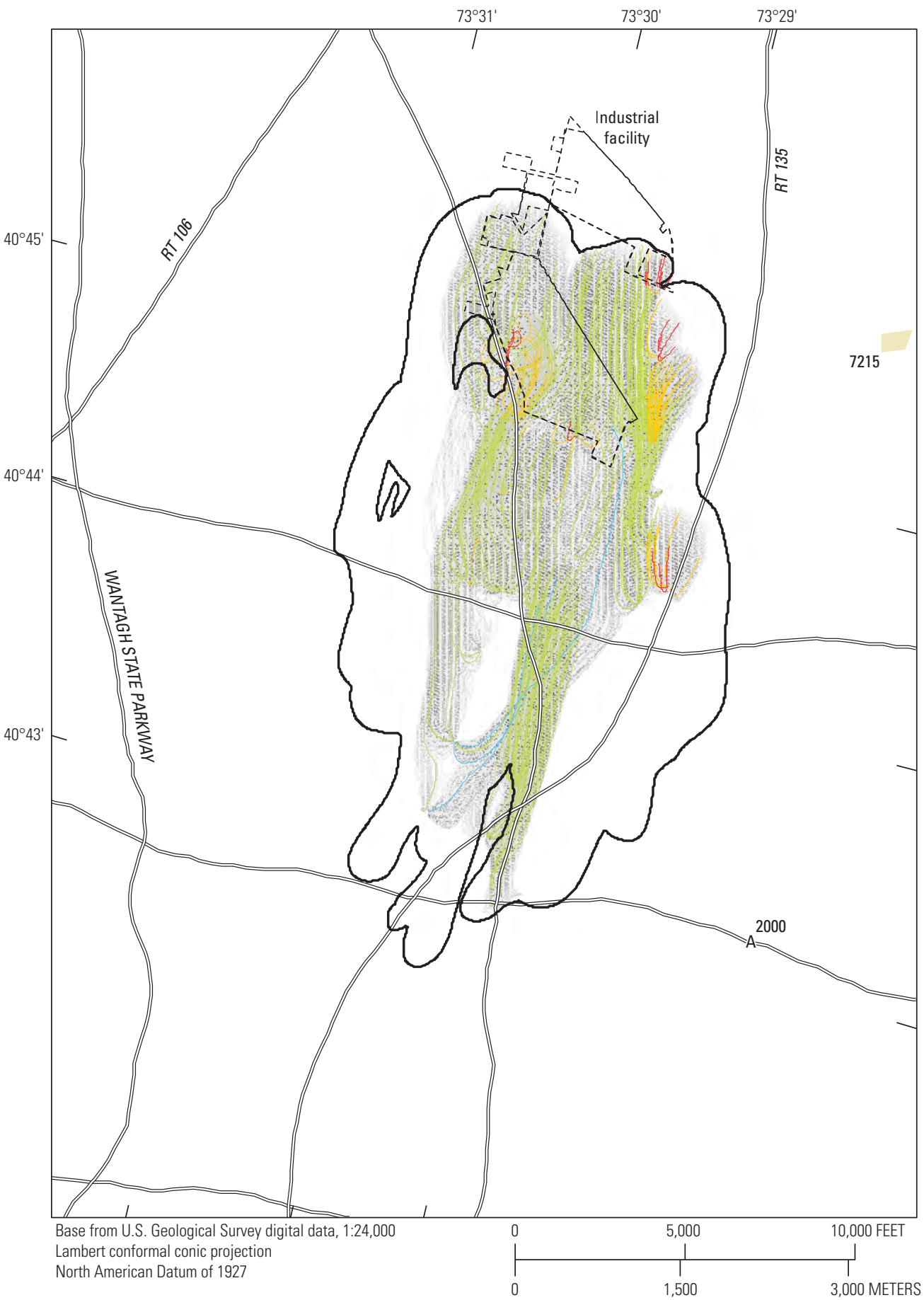

EXPLANATION

— SCG plume

Pathline-Color indicates residence time from start at SCG plume to well capture, other discharge, or lateral exit beyond extent of map. For each grouping, 4 percent of pathlines is shown in color; other pathlines shown in grey

Less than 5 years

5.01 to 10 years

10.01 to 50 years

50.01 to 100 years

More than 100 years

2650

Augmented streamflow—Massapequa Creek, rate in gallons per minute, applied to water table (model layer 1)

7125 Central basin-Recharge rate in gallons per minute, applied to water table (model layer 1)

Figure 24. -Continued 


\section{Scenario $5 \mathrm{~A}$}
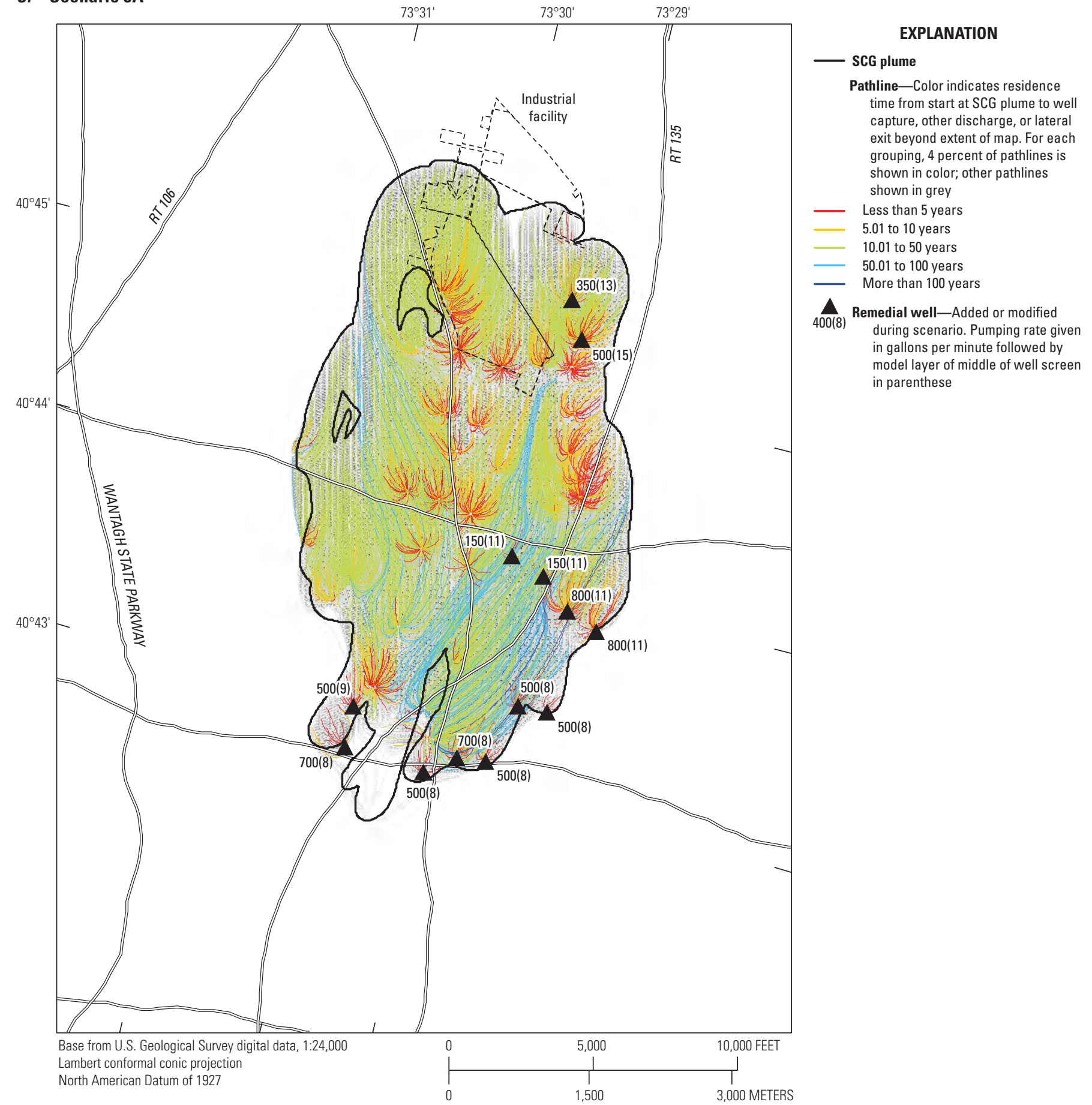

Figure 24. - Continued 


\section{Scenario 5B}

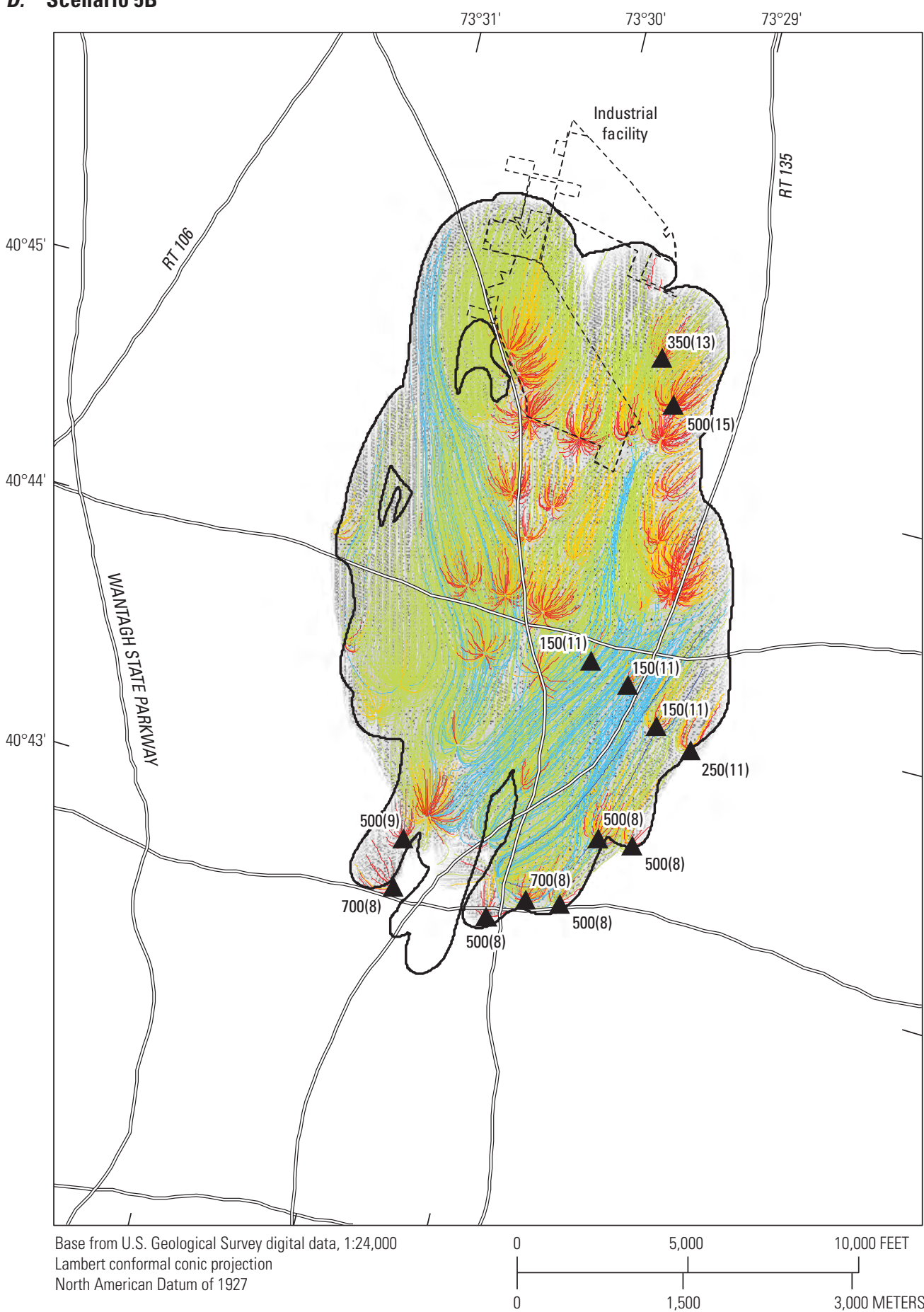

EXPLANATION

- SCG plume

Pathline-Color indicates residence time from start at SCG plume to well capture, other discharge, or lateral exit beyond extent of map. For each grouping, 4 percent of pathlines is shown in color; other pathlines shown in grey

Less than 5 years

5.01 to 10 years

10.01 to 50 years

50.01 to 100 years

More than 100 years

$\Delta$

Remedial well—Added or modified during scenario. Pumping rate given in gallons per minute followed by model layer of middle of well screen in parenthese

Figure 24. - Continued 


\section{E. Scenario 5A}

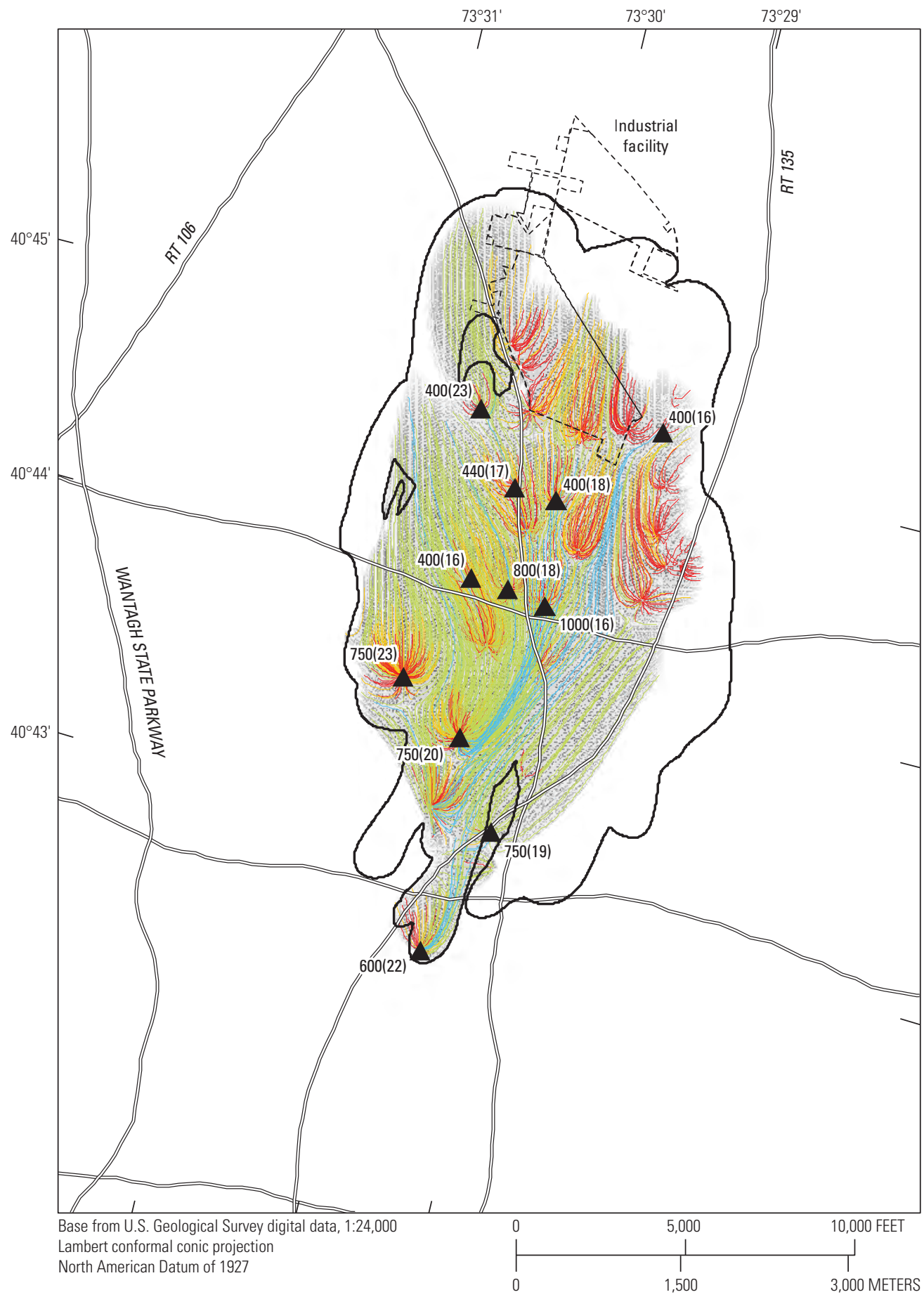

EXPLANATION

\section{- SCG plume}

Pathline-Color indicates residence time from start at SCG plume to well capture, other discharge, or lateral exit beyond extent of map. For each grouping, 4 percent of pathlines is shown in color; other pathlines shown in grey

Less than 5 years

5.01 to 10 years

10.01 to 50 years

50.01 to 100 years

More than 100 years

$\triangle R$

Remedial well-Added or modified during scenario. Pumping rate given in gallons per minute followed by model layer of middle of well screen in parenthese

Figure 24. - Continued 


\section{F. Scenario 5B}

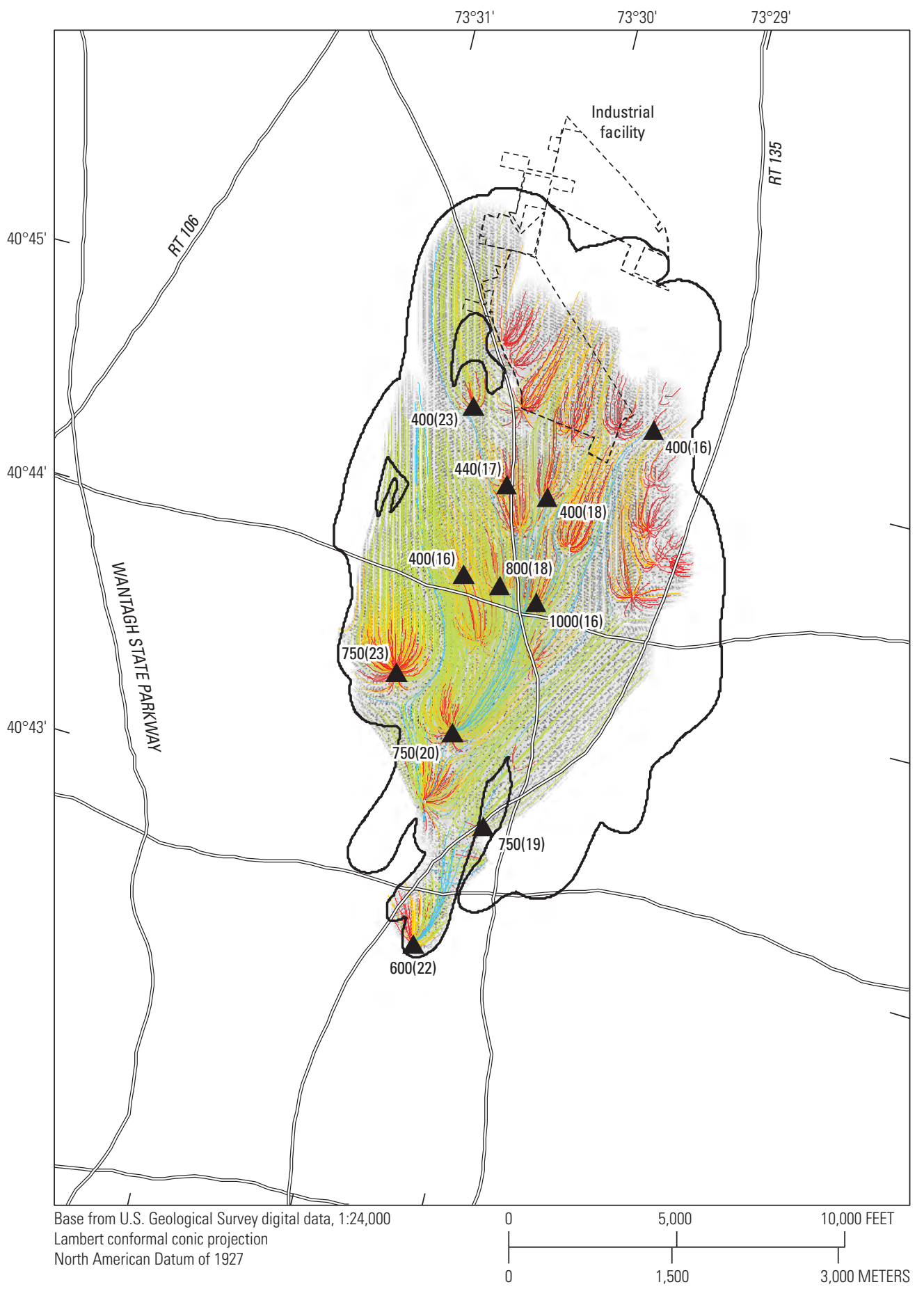

EXPLANATION

- SCG plume

Pathline-Color indicates residence time from start at SCG plume to well capture, other discharge, or lateral exit beyond extent of map. For each grouping, 4 percent of pathlines is shown in color; other pathlines shown in grey

Less than 5 years

5.01 to 10 years

10.01 to 50 years

50.01 to 100 years

- More than 100 years

Remedial well—Added or modified during scenario. Pumping rate given in gallons per minute followed by model layer of middle of well screen in parenthese

Figure 24. - Continued 


\section{A. Scenario 5A}

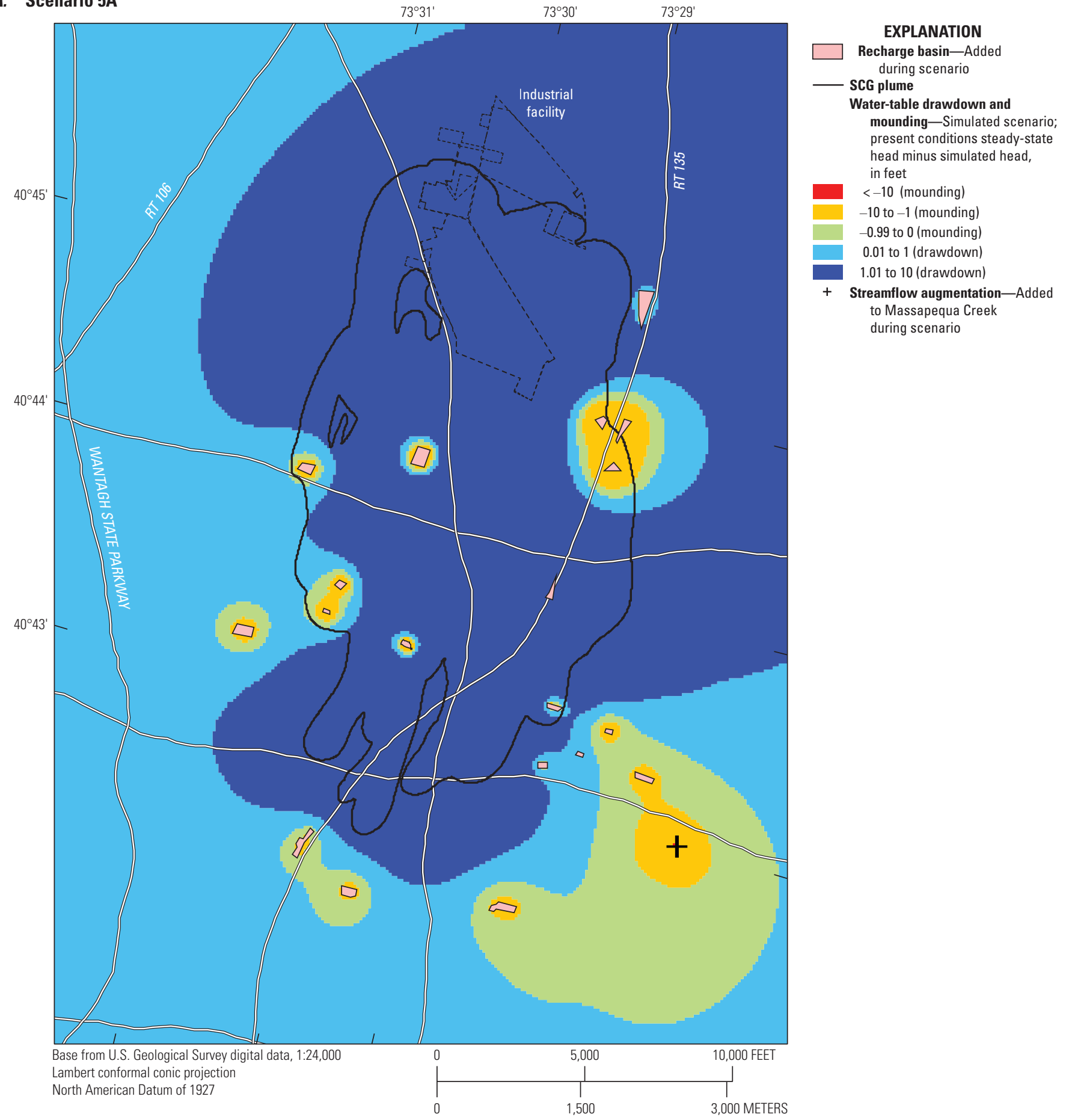

Figure 25. Maps showing changes in the locations of treated-water return and the simulated water table in scenarios $A, 5 \mathrm{~A}$ and $B, 5 \mathrm{~B}$ from scenario 1, southeastern Nassau County, New York. 


\section{B. Scenario 5B}

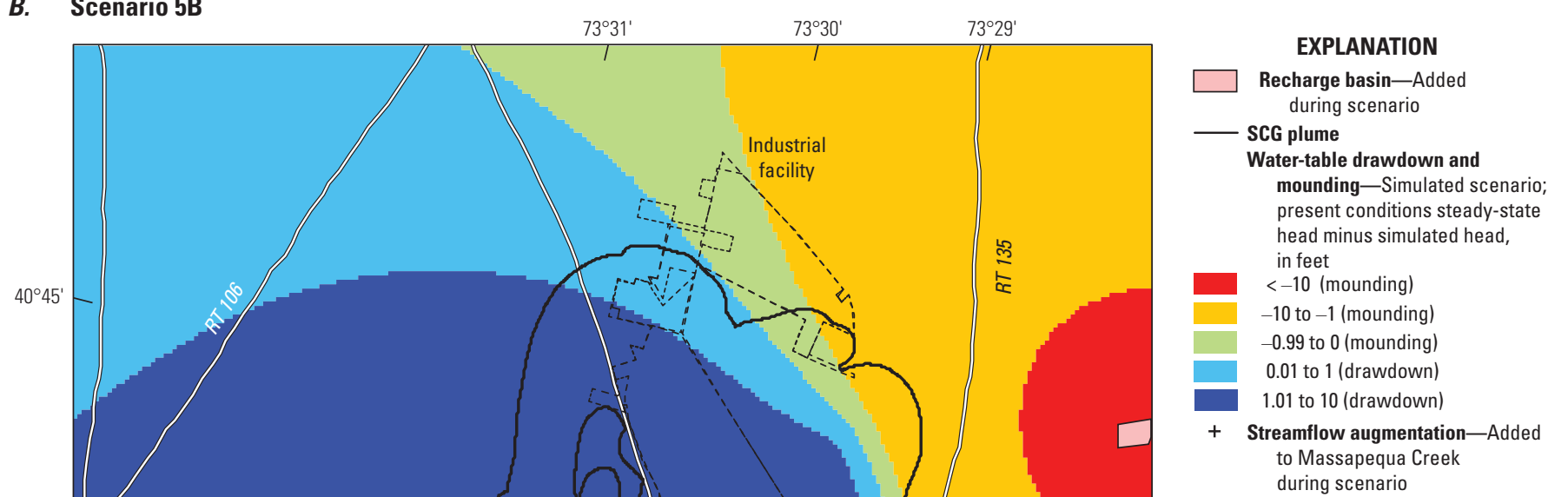

$40^{\circ} 44$

$40^{\circ} 43$

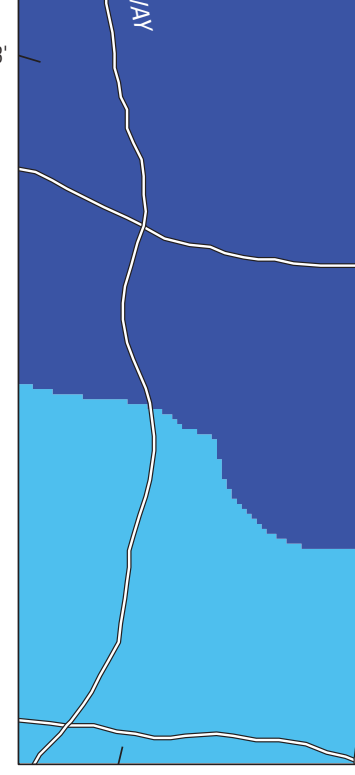

Base from U.S. Geological Survey digital data, 1:24,000

Lambert conformal conic projection

North American Datum of 1927

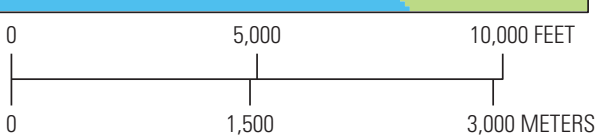

during scenario

plume

in feet

(diawdown)

Figure 25. - Continued 


\section{Limitations of Analysis}

Limitations of the MODFLOW groundwater-flow model and MODPATH particle tracker include the representation of hydrogeologic framework and hydrologic stress. Flowmodel limitations affect the accuracy of predicting the fates of plumes because particle-tracking analyses follow simulated flow fields. Groundwater-flow-model limitations also include factors affecting representation of hydrologic stresses, including well pumpage, natural groundwater discharges, and recharge. As climate-change-driven sea-level rise accelerates (Nerem and others, 2018), the steady-state assumption of the flow model may also be considered a limitation. For example, as sea level rises, the water table also rises because of the relative buoyancy of freshwater and likely results in increased stream discharge.

The assumptions of steady-state pumping and recharge limit the accuracy of the delineations presented in this report. Well pumping has changed during the timespan of the plumes. For example, the greater depth of the western OU2 plume compared with the eastern OU3 plume is likely due in part to the discontinued operation of a geothermal cooling plant that used deep pumping wells (Smolensky and Feldman, 1995). As more information about the plumes becomes available in the future, it may be necessary to adjust well pumping rates and locations. Although the steady-state period represents longterm average recharge conditions, droughts and other recharge variations are likely to occur in the future.

Particle-tracking limitations include the number and placement of particles, the treatment of weak sinks, and uncertainty in porosity parameterization. The MODPATH technique is not calibrated quantitatively through comparison of particletracking results with relevant observations of the actual system, such as water-quality data or changes in the plume size and shape over time. Particles are placed at the centroids of model cells that intersect a given plume-shell delineation (for the SCG plume, this resulted in a group of 144,947 particles; table 11). A greater number of particles may result in a more precise depiction of the plume, but also in visualization problems and more computational expense.

Weak sinks occur in cells where only a fraction of water entering the cell exits through well pumping, with the remainder exiting at other boundaries, such as the sides of model cells. A focus-area model cell is typically 100 by 100 by $40 \mathrm{ft}$; at this cell volume, wells pumping more than $50 \mathrm{gal} / \mathrm{min}$ typically dominate the cell water budget, creating a strong sink condition (all water entering the cell exits through well pumping). In a few cases, only a part of a well screen is present in a model cell, creating a weak-sink condition. Particles are stopped in these cases. The tracking of particles through weak sinks is indeterminate, and a choice is necessary whether to stop the particle (assume that it is captured by the weak sink) or continue the particle (assume that the particle is not captured by the weak sink). Although it may be considered more conservative with respect to remedial design to allow particles to travel through weak sinks, this approach does not accurately represent the capture potential of the weak sink: it results in cells where particles accumulate due to well hydraulic influence but ultimately pass through the cell. In this study, a few weak sinks occur, and particles are stopped there. If particles are allowed to continue through weak sinks, a more aggressive remedial-system design may be used with increased remedial pumping rates

MODPATH particles do not represent mass in this analysis. Particles are evenly distributed throughout plume shells without greater density in high-concentration zones. The hydraulics of mixing treated water with plume water are simulated in MODFLOW, but there is no mechanism for simulating diffusion or dispersion with respect to particles or other natural attenuation processes such as biodegradation. Therefore, the time necessary to achieve water-quality goals may be overestimated by particle travel times. During the course of the study, preliminary scenarios featuring distributed treated-water recharge basins were simulated with additional particles placed at points of recharge. It was observed that a large fraction of the additional particles was similarly captured by remedial pumping wells.

\section{Recharge Scenarios}

Within the regional model, recharge is specified by using a soil-water-balance approach. Model simulated discharges (boundary conditions shown in fig. 4), production well heads (locations shown in fig. 5), and calibration statistics (target locations shown in fig. 6) are sensitive to recharge parameters when varied within a reasonable range of uncertainty as given in the automated parameter-estimation ranges of table 6. Simulated heads and outflows increase in response to increased recharge (fig. 26A, $B, C, D$ ). If total natural recharge is increased by 20 percent, depth to water (unsaturated-zone thickness) decreases by an average of about $8 \mathrm{ft}$ at NAVFACmeasured wells and by $7.1 \mathrm{ft}$ at USGS-measured shallow water-table well N1259 (tables 4, 5, and 7). If baseline natural recharge is underestimated, then scenario mounding may also be underestimated. During scenario simulation, maximum water-table mounding that forms as a result of treated-water disposal at the hypothetical central basin in Bethpage State Park is about $66 \mathrm{ft}$ above NAVD 88 (scenario 5B; fig. 25), which is approximately $4 \mathrm{ft}$ below land surface. The model is also based on the assumption that there are no low-permeability layers beneath the central basin. Thus, it is possible that mounding is underestimated, and that groundwater may flood given the current configuration of the central basin. The basin area may be enlarged to address this potential problem.

As total natural-groundwater recharge is increased above the level of the baseline present- conditions model, more particles started within plumes tend to discharge from the upper glacial aquifer at wells, the coastline, wetlands, or streams. This discharge pattern also results in a decrease in Magothyaquifer discharge points at wells or points of subsea discharge 
A. Calibration statistics

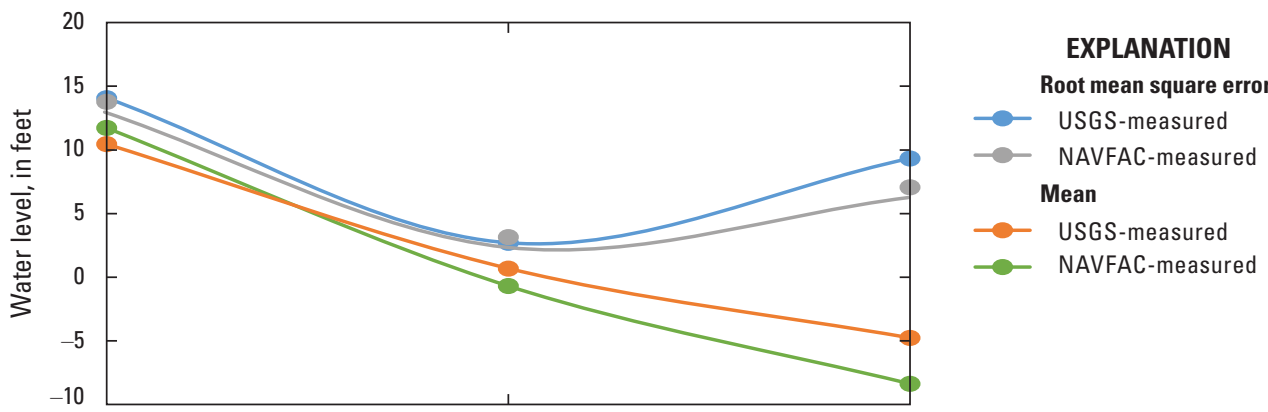

B. Production well heads

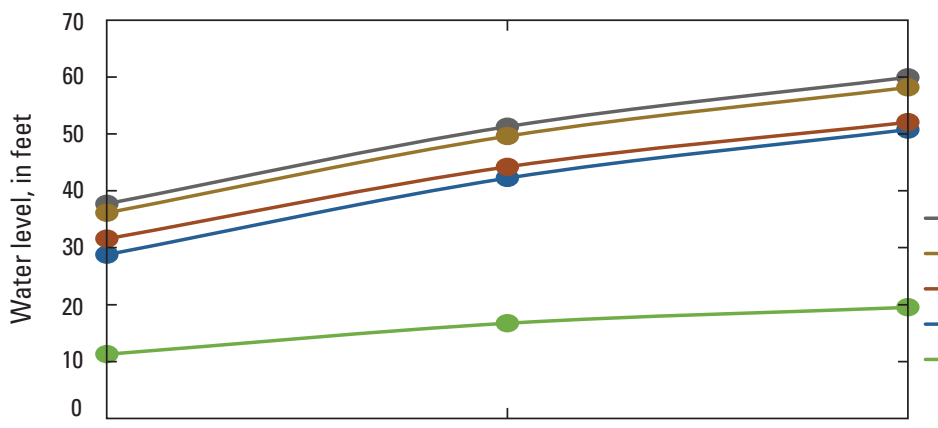

EXPLANATION

Well-Number listed in parentheses is production well number listed in tables 3 and 12 of this report; BWD number is assigned by the Bethpage Water District BWD 6-1 (N3876)

BWD 6-2 (N8941)

BWD 5-1 (N8004)

BWD 4-1 (N6915)

BWD 4-1 (N6915)

\section{Streamflow}

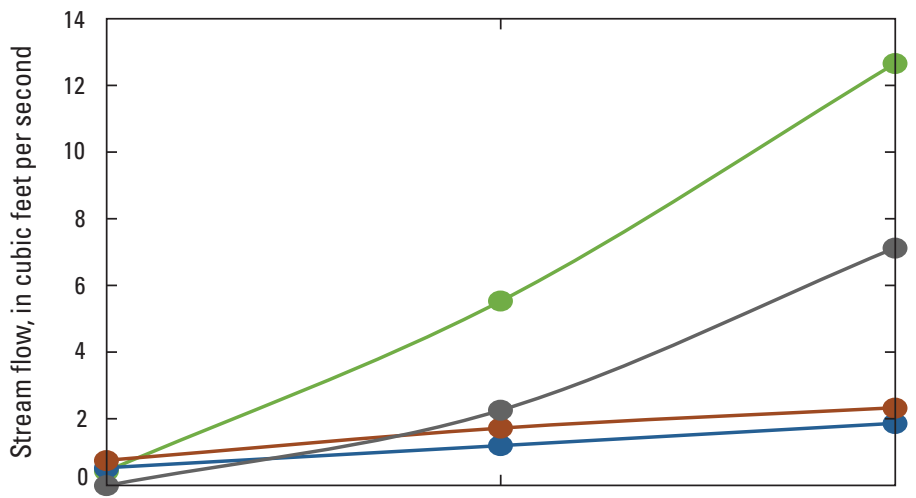

EXPLANATION

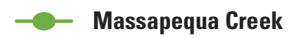

- - Seamans Creek

- Seaford Creek

- Belmore Creek-Base

D. Coastal and subsea boundary flow

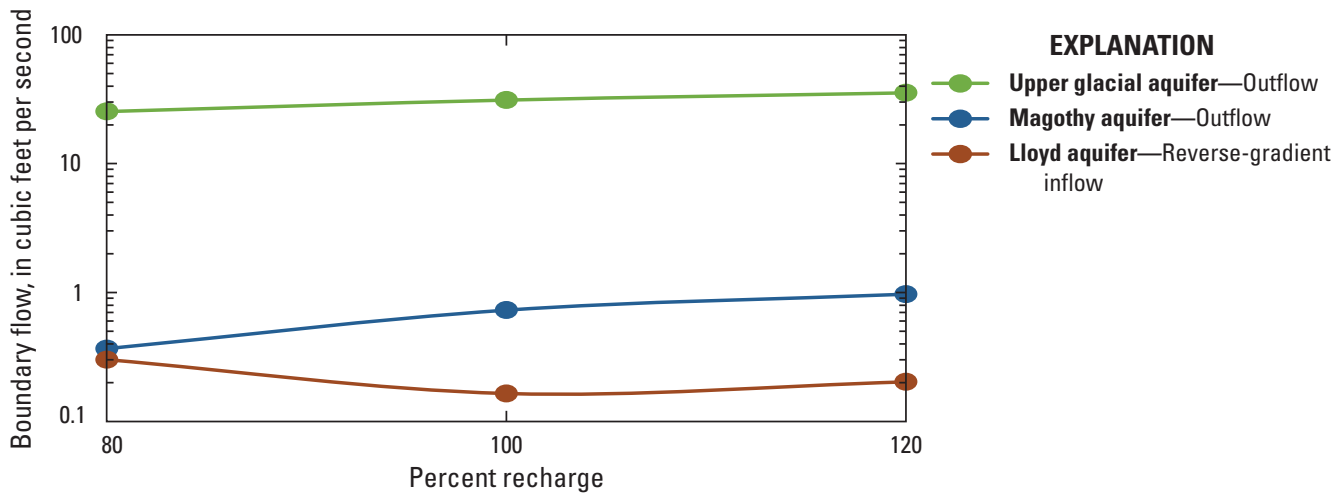

Figure 26. Graphs showing effects of variation in total natural recharge on the present-conditions steady-state MODFLOW model, southeastern Nassau County, New York; $A$, calibration statistics; $B$, head levels at production wells; $C$, streamflow; and $D$, coastal and subsea discharge. USGS, U.S. Geological Survey; NAVFAC, Naval Facilities Engineering Command. 


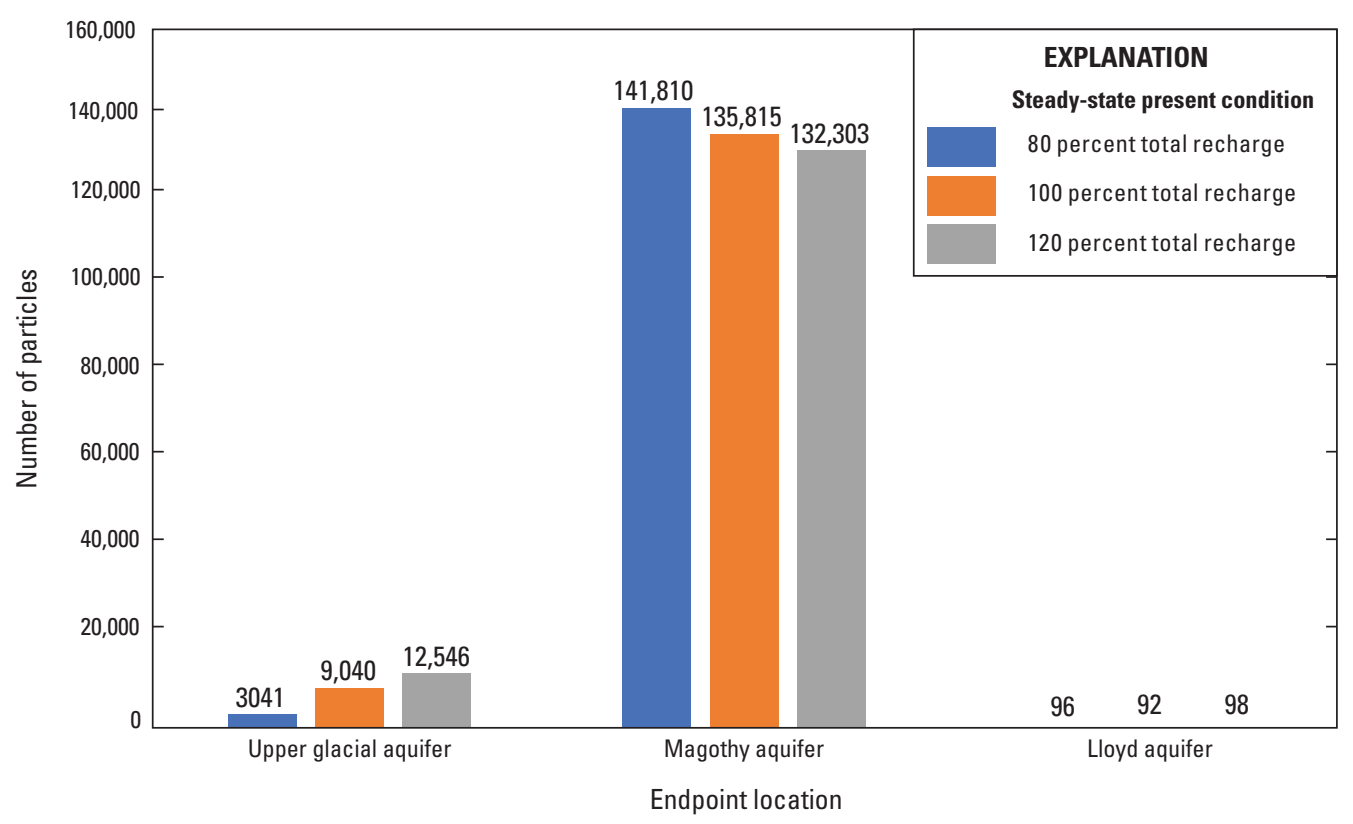

Figure 27. Graph showing effects of variation in total natural recharge on the present-conditions steady-state endpoint locations for the New York State Department of Environmental Conservation (NYSEDC) standards, criteria, and guidance (SCG) plume (HDR, 2019) in southeastern Nassau County, New York.

(discharge from the freshwater aquifer into saline groundwater beneath the seafloor; fig. 26D). As total recharge is decreased, more particles discharge within the Magothy aquifer (fig. 27). The number of particles discharging within the Lloyd aquifer is not sensitive to variations in total natural recharge of plus or minus 20 percent.

\section{Sensitivity Analysis}

Sensitivity to hydraulic conductivity and boundarycondition conductance parameters was analyzed over reasonable ranges of uncertainty as given in the automated parameter-estimation ranges of table 6 . Insensitive parameters whose variations over reasonable ranges result in less than a 0.1 -ft change in root-mean-square error-calibration statistics include all boundary condition conductances, Gardiners clay layer vertical hydraulic conductivity $(\mathrm{Kv})$, and lower Magothy high hydraulic conductivity (>100 ft/d) zone Kv.
Minor parameters whose variations over reasonable ranges result in less than a 2 -ft change in root-mean-square errorcalibration statistics include the Magothy aquifer valley fill zone Kv and Raritan confining unit Kv. None of these tests resulted in plume particles escaping capture during remedial scenarios 2 through 5 .

Within particle-tracking simulations, porosity is an uncalibrated, uniformly distributed parameter that is inversely correlated to particle velocity. Analysis of travel-time sensitivity to modest changes in porosity indicates similarly modest changes in mean travel times for all but the present steady state and baseline scenario 1 (fig. 28). These differences are due to the lack of escaping particles and larger remedial stresses in scenarios 2 through 5 that exert relatively strong control on advective groundwater flow and the resulting particle movement. Simulations where porosity was spatially distributed on the basis of hydraulic-conductivity distribution did not result in plume particles escaping capture during remedial scenarios 2 through 5 . 


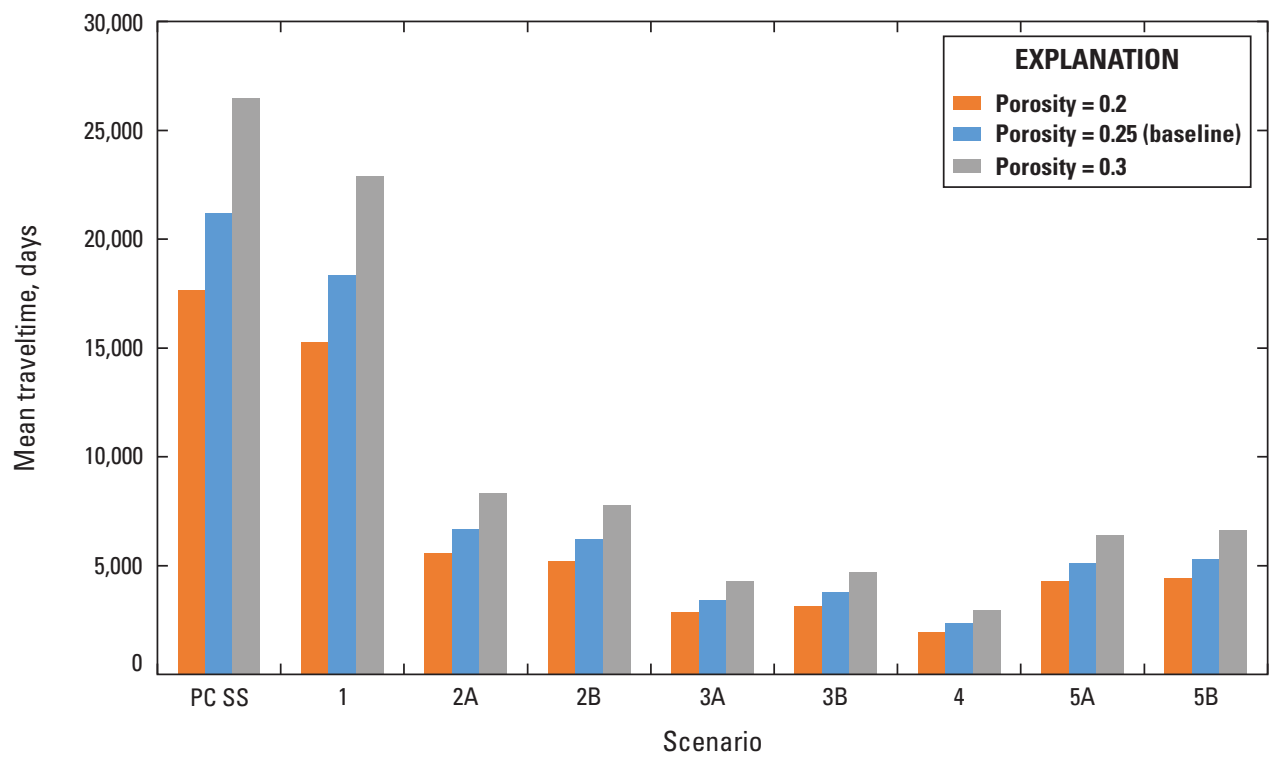

Figure 28. Graph showing sensitivities of mean travel times in the New York State Department of Environmental Conservation (NYSEDC) standards, criteria, and guidance (SCG) plume (HDR, 2019) of scenario particles to porosity, southeastern Nassau County, New York. Baseline value is listed in table 5. PC SS, present-condition steady-state.

\section{Summary}

Several plumes of dissolved volatile organic compounds (VOCs) have been identified in a sole-source aquifer near southeastern Nassau County, New York. To determine the effects of remedial scenarios on the movements of the plumes, advective groundwater-flow patterns were simulated, and particle tracking was analyzed in forward mode. Simulated hydrologic effects included cones of depression near pumping wells and water-table mounding near points of treated-water recharge. Insight was provided on the optimal number, location, and screen zone of recovery wells, and possible options for managing treated water. Particle pathlines were shown to be influenced by hydrogeologic-framework features and the interplay of nearby hydrologic stresses. During both present and hypothetical future conditions, some particles are captured by nearby public-supply wells. During hypothetical future conditions, most particles are intercepted by remedial-system pumping prior to reaching supply wells or surface-water receiving bodies.

Eight hypothetical remedial scenarios were used to explore alternative rates and locations of extraction wells and points of treated-water return. Total extraction rates varied from about 7,960 gallons per minute during an anticipated near-future condition to about 21,300 gallons per minute during full hydraulic containment of all site-related compounds to maximum contaminant limits with additional targeting of high-concentration zones. Characteristic traveltime is related to the type of plume simulated and other factors, including the degree of targeting of high-concentration zones of plumes.
Scenario 1 represents steady-state current conditions (2010-2015) with added near-term planned remedial action and is evaluated with respect to control of a New York State Department of Environmental Conservation (NYSEDC) standards, criteria, and guidance (SCG) plume. Scenario 2 represents a remedial system that is optimized to capture site contaminants where concentrations are above SCG standards with return of treated water at the land surface by using distributedrecharge basins and Massapequa Creek flow-augmentation alone or in combination with a centralized recharge basin. Scenario 3 represents a remedial system that is optimized to capture site contaminants above 50 parts per billion (ppb) total chlorinated volatile organic compounds (TCVOCs), returns water through distributed-recharge basins alone or in combination with a centralized recharge basin, and includes a focus on the capture of highly concentrated parts of plumes. Scenario 4 represents a remedial system that is optimized to capture site contaminants above $100 \mathrm{ppb}$ TCVOCs and to return water via injection wells and that includes a focus on the capture of highly concentrated parts of plumes. Scenario 5 represents a remedial system that is optimized to capture site contaminants above SCG standards and to return water by using distributedrecharge basins and Massapequa Creek flow-augmentation alone or in combination with a centralized recharge basin.

The location of treated-water recharge basins in relation to remedial pumping wells is an important factor in remedial design, and scenarios typically feature versions with distributed basins alone and in combination with a centralized basin to explore the effects of recharge centralization. Due to the offsetting of the recharge from pumping in the B scenario versions, there is less mixing of recharge water with plume 
water. There is also less stream discharge during centralbasin simulations due to the decrease of recharge distributed at nearby points. Within a water-budget zone downgradient from the model-focus area, there is also decreased drain and shoreline discharge; however, because remedial pumping amounts are balanced by treated water return, net effects at farremoved freshwater/saltwater interfaces and coastal wetlands are negligible.

\section{Selected References}

Arcadis, 2003, Comprehensive groundwater model report-U.S. Naval Weapons Industrial Reserve Plant/ Northrup Grumman: Melville, N.Y., Arcadis, April 28, [n.p.]

Arcadis, 2009, Remedial investigation report (study area groundwater), operable unit 3 (former Grumman settling ponds), Bethpage, New York: Melville, N.Y., Arcadis, 111 p., appendixes.

Buxton, H.T., and Smolensky, D.A., 1999, Simulation of the effects of development of the ground-water flow system of Long Island, New York: U.S. Geological Survey WaterResources Investigations Report 98-4069, 57 p. [Also available at https://doi.org/10.3133/wri984069.]

Charles, E.G., 2016, Regional chloride distribution in the Northern Atlantic Coastal Plain aquifer system from Long Island, New York, to North Carolina: U.S. Geological Survey Scientific Investigations Report 2016-5034, 37 p., appendixes, accessed June 4, 2019, at https://doi.org/ 10.3133/sir20165034.

Getzen, R.T., 1977, Analog-model analysis of regional threedimensional flow in the ground-water reservoir of Long Island, New York: U.S. Geological Survey Professional Paper 982, 49 p., accessed August 3, 2019, at https://doi.org/ $10.3133 / \mathrm{pp} 982$.

Harbaugh, A.W., 2005, MODFLOW-2005, the U.S. Geological Survey modular ground-water model-The ground-water flow process: U.S. Geological Survey Techniques and Methods, book 6, chap. A16, [variously paginated], accessed June 2019 at https://doi.org/10.3133/ tm6A16.

Henningson, Durham \& Richardson Architecture and Engineering, P.C. (HDR), 2019, Northrup Grumman Bethpage facility (operable units 2 and 3) and Naval Weapons Industrial Reserve Plant (operable unit 2): New York State Department of Environmental Conservation feasibility study report, work assignment D007625-32, April, [n.p.].
McDonald, M.G., and Harbaugh, A.W., 1988, A modular three-dimensional finite-difference ground-water flow model: U.S. Geological Survey Techniques of WaterResources Investigations, book 6, chap. A1, 586 p. [Also available at https://doi.org/10.3133/twri06A1.]

Misut, P.E., 2011, Simulation of groundwater flow in a volatile organic compound-contaminated area near Bethpage, Nassau County, New York-A discussion of modeling considerations: U.S. Geological Survey OpenFile Report 2011-1128, 19 p., accessed August 3, 2019, at https://doi.org/10.3133/ofr20111128.

Misut, P.E., 2014, Simulation of zones of contribution to wells at site GM-38, Naval Weapons Industrial Reserve Plant, Bethpage, New York: U.S. Geological Survey Scientific Investigations Report 2014-5036, 58 p., accessed August 3, 2019, at https://doi.org/10.3133/sir20145036.

Misut, P.E., 2018, Simulation of zones of contribution to wells south of the Naval Weapons Industrial Reserve Plant, Bethpage, New York: U.S. Geological Survey Scientific Investigations Report 2017-5161, 45 p., accessed August 3, 2019, at https://doi.org/10.3133/sir20175161.

Misut, P.E., 2020, MODFLOW-NWT and MODPATH6 model use to analyze remedial scenarios affecting plume movement through a sole-source aquifer system, southeastern Nassau County, New York: U.S. Geological Survey data release, https://doi.org/10.5066/P9DOBQ8N.

Nerem, R.S., Beckley, B.D., Fasullo, J.T., Hamlington, B.D., Masters, D., and Mitchum, G.T., 2018, Climatechange-driven accelerated sea-level rise detected in the altimeter era: Proceedings of the National Academy of Sciences of the United States of America, v. 115, no. 9, p. 2022-2025. [Also available at https://doi.org/10.1073/ pnas.1717312115.]

New York State Department of Environmental Conservation, 2019, Northrup Grumman Bethpage facility and Naval Weapons Industrial Reserve Plant site nos. 130003 A \& 130003B, December 2019-Amended record of decision. New York State Department of Environmental Conservation, $299 \mathrm{p}$.

New York State Department of Environmental Conservation, [undated], Index of standards, criteria and guidance (SCGs) for investigation and remediation of inactive hazardous waste disposal sites: New York State Department of Environmental Conservation web page, accessed June 2, 2019, at http://www.dec.ny.gov/regulations/61794.html.

Poeter, E.P., Hill, M.C., and Banta, E.R., Mehl, S., and Christensen, S., 2005, UCODE_2005 and six other computer codes for universal sensitivity analysis, calibration, and uncertainty evaluation: U.S. Geological Survey Techniques and Methods, book 6, chap. A11, 283 p., accessed March 3, 2019, at https://doi.org/10.3133/tm6a11. 
Pollock, D.W., 1994a, Source code and ancillary data files for the MODPATH particles tracking package of the groundwater flow model MODFLOW: U.S. Geological Survey Open-File Report 94-463, 2 CD-ROMs. [Also available at https://doi.org/10.3133/ofr94463.]

Pollock, D.W., 1994b, User's guide for MODPATH/ MODPATH-PLOT, version 3; a particle tracking postprocessing package for MODFLOW, the U.S. Geological Survey finite-difference ground-water flow model: U.S. Geological Survey Open-File Report 94-464, 248 p. [Also available at https://doi.org/10.3133/ofr94464.]

Pollock, D.W., 2012, User guide for MODPATH version 6-A particle-tracking model for MODFLOW: U.S. Geological Survey Techniques and Methods, book 6, chap. A41, 58 p., accessed March 3, 2019, at https://doi.org/10.3133/tm6A41.

Reilly, T.E., and Harbaugh, A.W., 2004, Guidelines for evaluating ground-water flow models: U.S. Geological Survey Scientific Investigations Report 2004-5038, 30 p. [Also available at https://doi.org/10.3133/sir20045038.]

Resolution Consultants, 2017, OU2 groundwater investigation data summary report: Los Angeles, Calif., Resolution Consultants, 136 p., accessed August 22, 2019, at https://www.navfac.navy.mil/niris/MID_ATLANTIC/ BETHPAGE_NWIRP/N90845_002079.pdf.

Smolensky, D.A., and Feldman, S.M., 1995, Threedimensional advective transport of volatile organic compounds in ground water beneath an industrial/residential area of Nassau County, New York: U.S. Geological Survey Water-Resources Investigations Report 92-4148, 53 p. [Also available at https://doi.org/10.3133/wri924148.]
Smolensky, D.A., Buxton, H.T., and Shernoff, P.T., 1989, Hydrogeologic framework of Long Island, New York: U.S. Geological Survey Hydrologic Atlas 709, 3 sheets, scale 1:250,000. [Also available at https://doi.org/10.3133/ ha709.]

Stumm, F., 1999, Hydrogeology and extent of saltwater intrusion of the Great Neck peninsula, Great Neck, Long Island, New York: U.S. Geological Survey Water-Resources Investigations Report 1999-4280, 41 p., accessed June 23, 2019, at https://doi.org/10.3133/wri994280.

Tetra Tech, 2012, Study of alternatives for management of impacted groundwater at NWIRP Bethpage: Naval Facilities Engineering Command, January, 188 p.

U.S. Geological Survey, 2019, USGS water data for the nation: U.S. Geological Survey National Water Information System database, accessed June 4, 2019, at https://doi.org/ 10.5066/F7P55KJN. [Surface-water-specific data can be found directly at https://nwis.waterdata.usgs.gov/ny/ nwis/sw.]

Westenbroek, S.M., Kelson, V.A., Dripps, W.R., Hunt, R.J., and Bradbury, K.R., 2010, SWB-A modified Thornthwaite-Mather soil-water-balance code for estimating groundwater recharge: U.S. Geological Survey Techniques and Methods, book 6, chap. A31, 60 p., accessed March 3, 2020, at https://doi.org/10.3133/tm6A31.

Winston, R.B., 2009, ModelMuse-A graphical user interface for MODFLOW2005 and PHAST: U.S. Geological Survey Techniques and Methods, book 6, chap. A29, 52 p., accessed March 3, 2020, at https://doi.org/10.3133/tm6A29.

Zheng, C., 1990, MT3D, a modular three-dimensional transport model for simulation of advection, dispersion and chemical reactions of contaminants in groundwater systems. U.S. Environmental Protection Agency, 170 p. 


\section{Appendix 1. Chemical Components of Plumes in Bethpage, New York}

Table 1.1. Chemical components of total chlorinated volatile organic compound and standards, criteria, and guidelines plumes.

[The standards, criteria, and guidelines plume are based on the New York State Department of Environmental Conservation (undated) standards, criteria, and guidelines (SCG) levels. Modified from Henningson, Durham \& Richardson Architecture and Engineering, P.C. (2019). TCVOC, total chlorinated volatile organic compound]

\begin{tabular}{l} 
Components of TCVOC plumes \\
\hline \multicolumn{1}{c}{$1,1,1-$ Trichloroethane } \\
\hline 1,1,2,2-Tetrachloroethane \\
1,1,2-Trichloroethane \\
1,1-Dichloroethane \\
1,1-Dichloroethene \\
1,2-Dichloroethane \\
1,2-Dichloroethene (cis, trans, and total) \\
Dichlorofluoromethane \\
Tetrachloroethene (PCE) \\
Trichloroethene (TCE) \\
Vinyl chloride \\
\hline Additional components of SCG plume \\
\hline 1,1,2,2-Tetrachloroethane \\
1,2-Dichloropropane \\
Chlorodifluoromethane \\
Toluene \\
Trichlorotrifluoroethane \\
Carbon tetrachloride \\
Chlorobenzene \\
1-4 Dioxane \\
Chromium \\
Nickel
\end{tabular}

\section{References Cited}

Henningson, Durham \& Richardson Architecture and Engineering, P.C., 2019, Northrup Grumman Bethpage facility (operable units 2 and 3) and Naval Weapons Industrial Reserve Plant (operable unit 2): New York State Department of Environmental Conservation feasibility study report, work assignment D007625-32, April, [n.p.].

New York State Department of Environmental Conservation, [undated], Index of standards, criteria and guidance (SCGs) for investigation and remediation of inactive hazardous waste disposal sites: New York State Department of Environmental Conservation website, accessed June 2, 2019, at http://www.dec.ny.gov/regulations/61794.html. 


\section{Appendix 2. Regional Model Construction for Groundwater Flow in Central Long Island, New York}

To simulate the groundwater-flow system of the central Long Island region surrounding the study focus area, a model was constructed from a grid of 25 layers, 617 columns, and 614 rows of 500 -foot (ft)-square cells. The regional model domain is about 30 miles (mi) long from north to south and $40 \mathrm{mi}$ wide extending from Queens to Suffolk Counties (fig. 2.1). The grid is rotated 18 degrees counterclockwise from true north. Vertically, the grid covers the entire depth of unconsolidated deposits with bedrock as the lower boundary and topobathymetry as the upper boundary.

Boundary conditions are used to represent surface-water features, freshwater/saltwater interfaces, recharge across the water table, and well pumping. Streams are represented by the MODFLOW drain package (fig. 2.2) with heads set to topography (fig. 2.1) and a calibrated-scalar conductance parameter. Saltwater marshes are represented by the MODFLOW Drain package (fig. 2.2) with heads set to $1 \mathrm{ft}$ above the North American Vertical Datum of 1988 (NAVD 88) and a calibrated-scalar conductance parameter. The shoreline and seafloor are represented by the MODFLOW general head package (fig. 2.2) with the hydrostatic head based on bathymetry (fig. 2.1) and a calibrated-scalar conductance parameter.

The MODFLOW general head package represents two subsea discharge zones (fig. 2.3). Subsea discharge moves from freshwater parts of the Magothy and Lloyd aquifers upward across confining units into saline parts, with boundary heads assumed to be hydrostatic with sea level and with separately calibrated Magothy and Lloyd scalar-conductance parameters. Freshwater/saltwater interfaces are at the landward side of subsea discharge zones (Charles, 2016).

Four groundwater-recharge distributions are summarized in figure $2.4 A-D$ : recharge from precipitation, rejected recharge from impervious surfaces, wastewater return flow, and leakages from water-supply infrastructure, respectively. Precipitation-driven recharges are based on soil-water-balance (SWB) methods described in Westenbroek and others (2010) and Masterson and others (2015). Soil-related datasets required for SWB are hydrologic soil group and available water capacity (Natural Resources Conservation Service, undated $a$ and $b$ ). Precipitation and temperature data were obtained from Oak Ridge National Laboratory (Thornton and others, 2014, 2017). Land-cover data were obtained from the U.S. Geological Survey (USGS) National Land Cover Database (Homer and others, 2007, 2015). Derived SWB input values are given in Misut (2020). Wastewater return-flow data were based on the population per grid cell in unsewered areas (fig. 2.4C); sewer-leakage values were based on the population per grid cell in sewered areas. Values of infiltration from leaky water-supply infrastructure were based on total road length per grid cell within public-service areas (fig. 2.4D).
Currently [2005-2015], about 317 million gallons per day of groundwater is withdrawn from the regional aquifer system for multiple uses including drinking water, contaminant remediation, and agricultural and industrial purposes (fig. 2.5). Wells are sparse in Queens County and near the northern coastlines of Nassau and Suffolk Counties. Wells in the ocean barrier islands are screened in deep confined aquifers typically overlain by saline groundwater. Most public-supply wells are screened within the Magothy aquifer.

Model layers generally follow hydrostratigraphic unit elevations and extents (figs. 2.6 and 2.7), derived from a synthesis of the elevations and extents developed by Smolensky and others (1989) with a revision of the Raritan clay-surface elevations to reflect recent drilling in the Bethpage area, and interpretations of Stumm (1999) along the north shore of Nassau County. In general, each of the primary regional confined aquifers and confining units is represented as a separate layer in the model. Additional layers were added to the Magothy and upper glacial aquifers to provide a better representation of pumping-well screen zones. Where a hydrogeologic unit does not extend across a given layer, a zone with a minimum thickness of $1 \mathrm{ft}$ was created, and the hydraulic properties of the overlying unit were applied to make the layer continuous across the model domain - a requirement of the finite-difference solution.

The upper glacial aquifer generally is represented by three model layers and is simulated as unconfined. The top of the model (layer 1), which represents the shallow part of the upper glacial aquifer, is land surface in onshore areas and the seabed in offshore areas. Cells in layer 1 with thicknesses of less than $1 \mathrm{ft}$ following truncation by the freshwater/saltwater interface were specified as inactive to remove stranded offshore cells. The elevation of the top of layer 2, which explicitly represents previously mapped intraglacial Wisconsin clays, where present, is derived from the surface elevations of those units. The elevation of the top of layer 3, representing deep parts of the upper glacial aquifer, is derived from the estimated bottom of the mapped intraglacial clays. The top of layer 4, which explicitly represents the Gardiners clay unit, where present, is based on the mapped surface elevation of that unit. Glacial sediments are represented in deep layers of the model where Cretaceous sediments are absent along the north shore of the island and in deep erosional channels within the shallow Cretaceous aquifers. The top of layer 5 is the mapped surface elevation of the shallow Cretaceous aquifers - the Magothy aquifer and the Monmouth greensand - and the surface elevation of the Jameco aquifer. The bottom of layer 23 is the surface of the Raritan clay unit. The bottoms of the intervening layers (6 through 22) were generally equal divisions of those two surfaces with the shallow Cretaceous aquifers and the Jameco aquifer represented by 19 model layers of equal thickness. The mapped extents and thicknesses of 
the Monmouth greensand and the Jameco aquifer were used to differentiate those units within that stack of model layers. The Cretaceous sediments are separated from the overlying glacial sediments by an unconformity, and numerous erosional channels are within the Cretaceous sediments. Glacial sediments are represented within these channels and in spaces where the shallow Cretaceous aquifers are absent. Shallow parts of the Pleistocene North Shore confining unit, along the north shore of Nassau County, are stratigraphically equivalent with the Magothy aquifer and are represented in this stack of model layers where the unit is present. Layer 24 of the model explicitly represents the Raritan confining unit. The bottom of the layer is the mapped surface elevation of the underlying Lloyd aquifer; deep parts of the North Shore confining unit are represented in this layer. Glacial sediments are represented where both the Raritan clay and North Shore confining unit are absent. Layer 25 represents the Lloyd aquifer. The bottom of the layer is the mapped surface elevation of the underlying crystalline bedrock. The layer represents the deepest overlying unit present at a given location where the Lloyd aquifer is absent.

Within the upper glacial, Jameco, and Magothy aquifers, a texture model (a representation of the baseline precalibrated distribution of hydraulic conductivity) based on borehole data was used to represent water-transmission properties and is described further by Walter and Finkelstein (2020). The boreholes generally were drilled as a part of water-supply development and, in some areas, remedial investigations. Standardized lithologic codes were assigned to each geologic depth interval in each borehole on the basis of keywords in lithologic descriptions. The estimated hydraulic conductivities differed for each lithologic type by aquifer; Cretaceous aquifers generally can be assumed to have lower hydraulicconductivity values than equivalent lithologic types in glacial aquifers because of the lesser degree of sorting and higher degree of compaction in the Cretaceous sediments. Mean values for 10 - $\mathrm{ft}$ intervals were calculated arithmetically for horizontal hydraulic conductivity $(\mathrm{Kh})$ and geometrically for vertical hydraulic conductivity (Kv). Mean values were used to interpolate conductivity fields by use of ordinary kriging for $10-\mathrm{ft}$ intervals from the land surface to a depth of $1,600 \mathrm{ft}$. Hydraulic conductivity in the shallow upper glacial aquifer near sea level ( -10 to $0 \mathrm{ft}$ relative to mean sea level) varies from about 30 feet per day (ft/d) in areas of central and northern parts of the island, generally corresponding to areas of ice-contact and moraine sediments, to about $200 \mathrm{ft} / \mathrm{d}$ to the south, within glacial outwash. Coarse sediments in the glacial sediments, identified by high hydraulic conductivities, are generally in the shallow parts of the aquifer, particularly near the south shore, where the gentle topography indicates a fluvial-outwash plain. Fine-grained sediments, identified by low hydraulic conductivities, are generally in deeper parts of the aquifer, particularly in the center of the island, where steep topography indicates glacial moraines. Hydraulic conductivities in deeper parts of the Magothy aquifer range from about 10 to about $150 \mathrm{ft} / \mathrm{d}$, and the sediments are more heterogeneous because of the greater number of depositional environments - including overbank marshes, fluvial channels, and near-shore deltaic environments. Coarse sediments are present in deeper parts of the Magothy aquifer-the basal Magothy is an important source of water-and fine-grained sediments are common in the middle parts of the aquifer.

In addition to conductivity distributions based on the texture model of Walter and Finkelstein (2020), multiplier-type parameter zones were applied during model calibration. The upper glacial aquifer was also divided into three zones based on depositional environment: ice-contact deposits, outwash plains, and moraines (fig. 2.8). Within units other than the upper glacial, Jameco, and Magothy aquifers, parameter zones were based on the hydrologic framework of Smolensky and others (1989). 


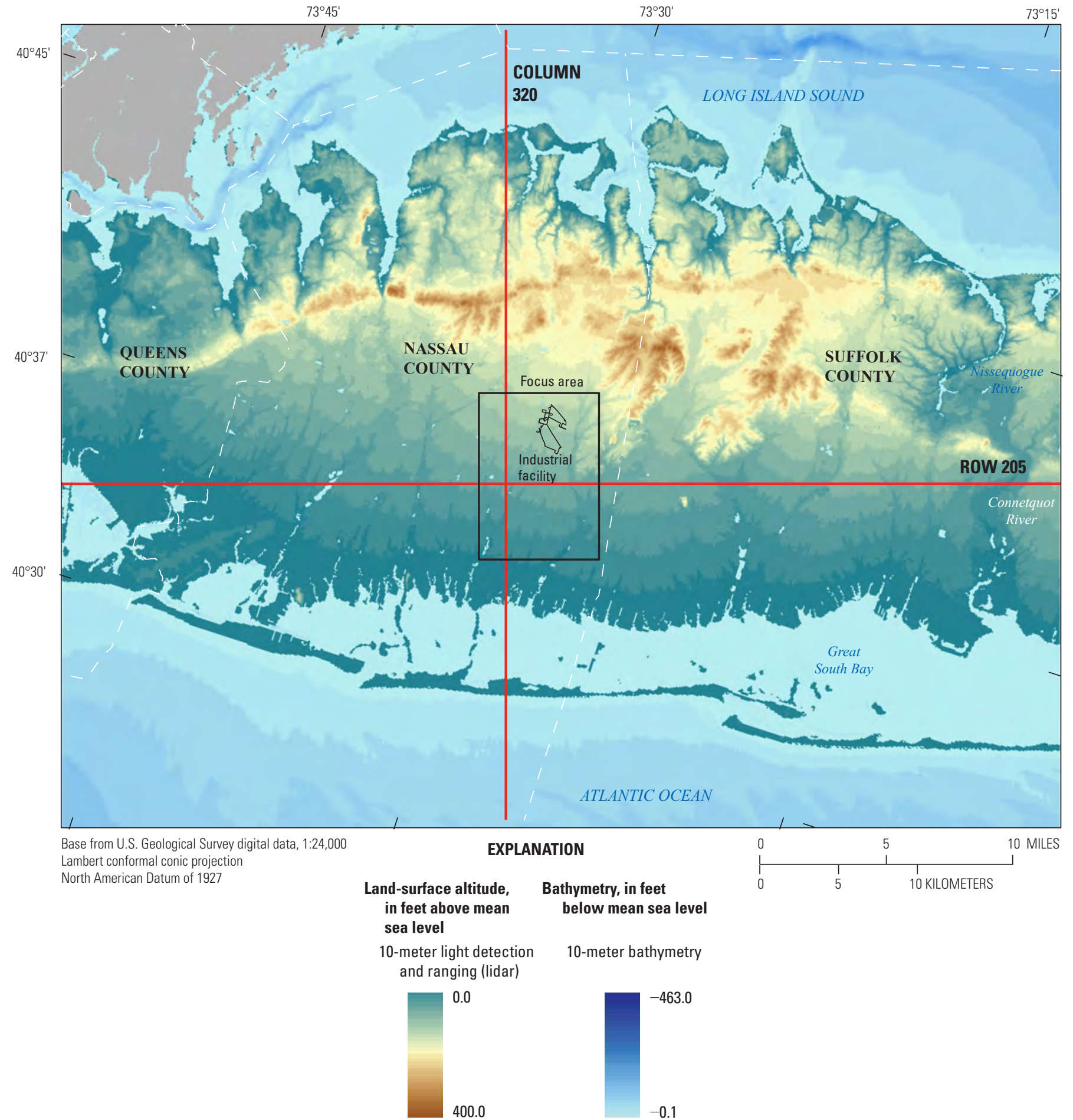

Figure 2.1. Map showing regional model domain with grid row and columns used for cross sections (fig 2.6A and $B$ ) and focus area, Long Island, New York. 


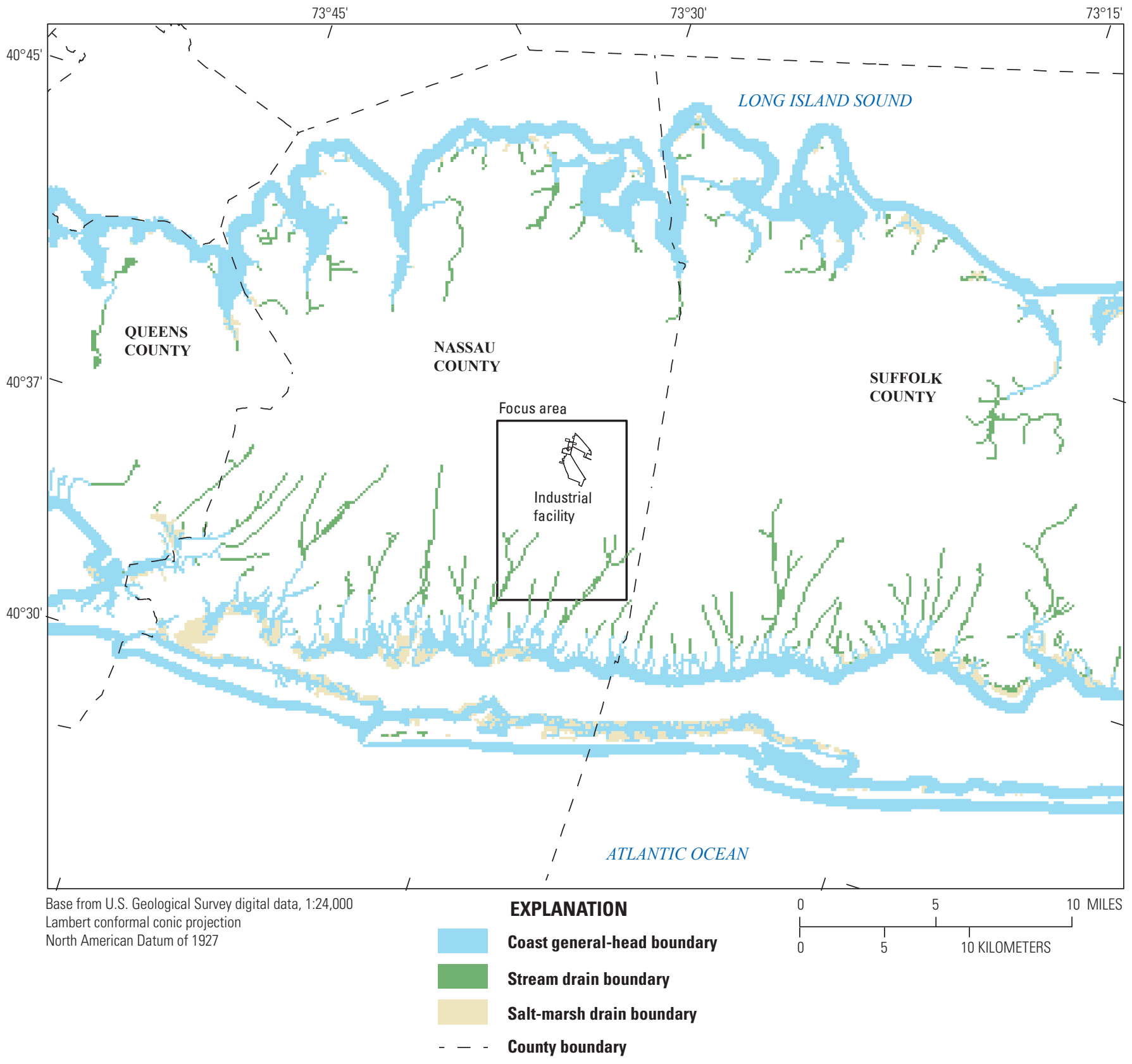

Figure 2.2. Map showing model top-layer boundaries, Long Island, New York. 


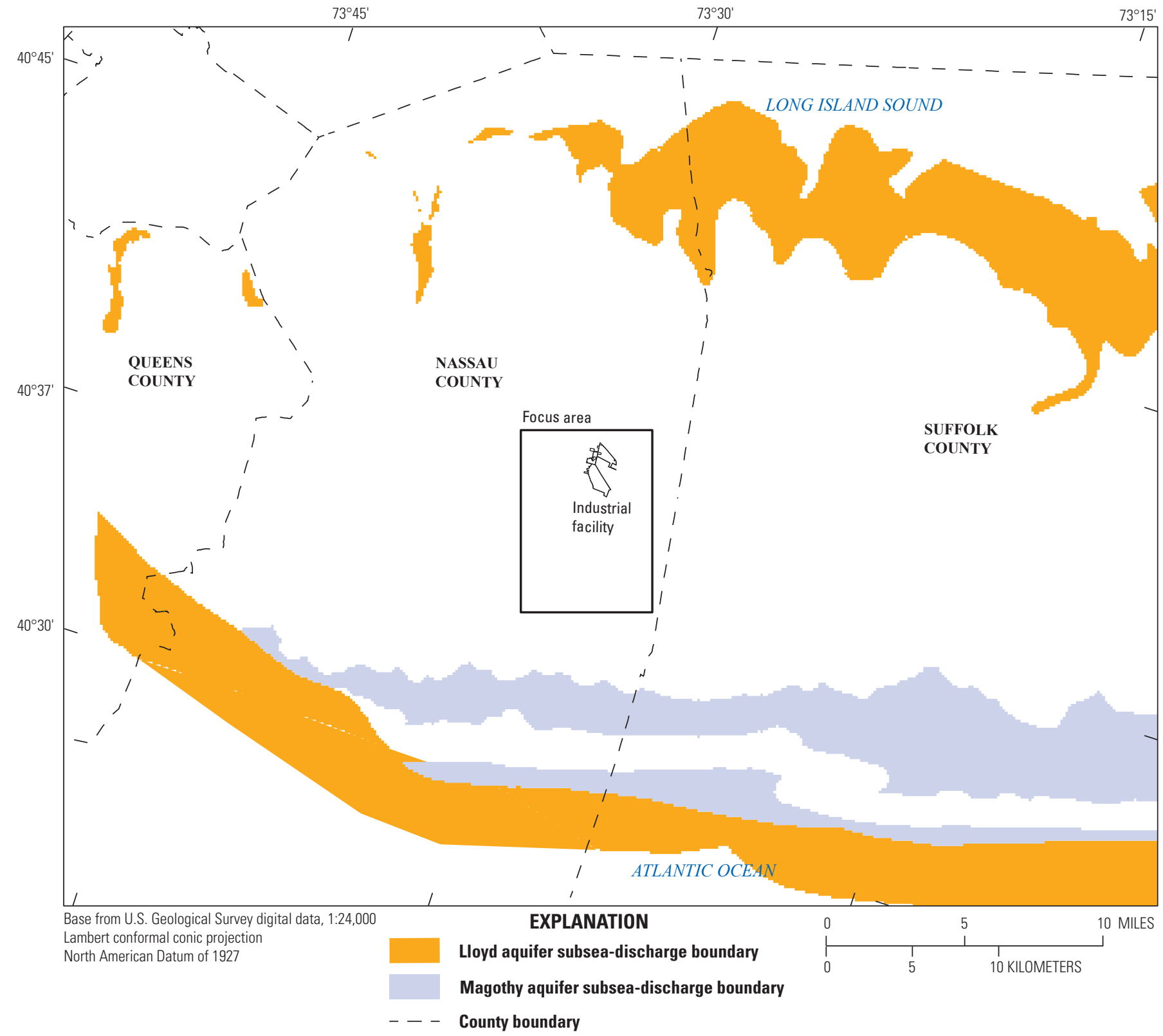

Figure 2.3. Maps showing model subsea discharge zones, Long Island, New York. 


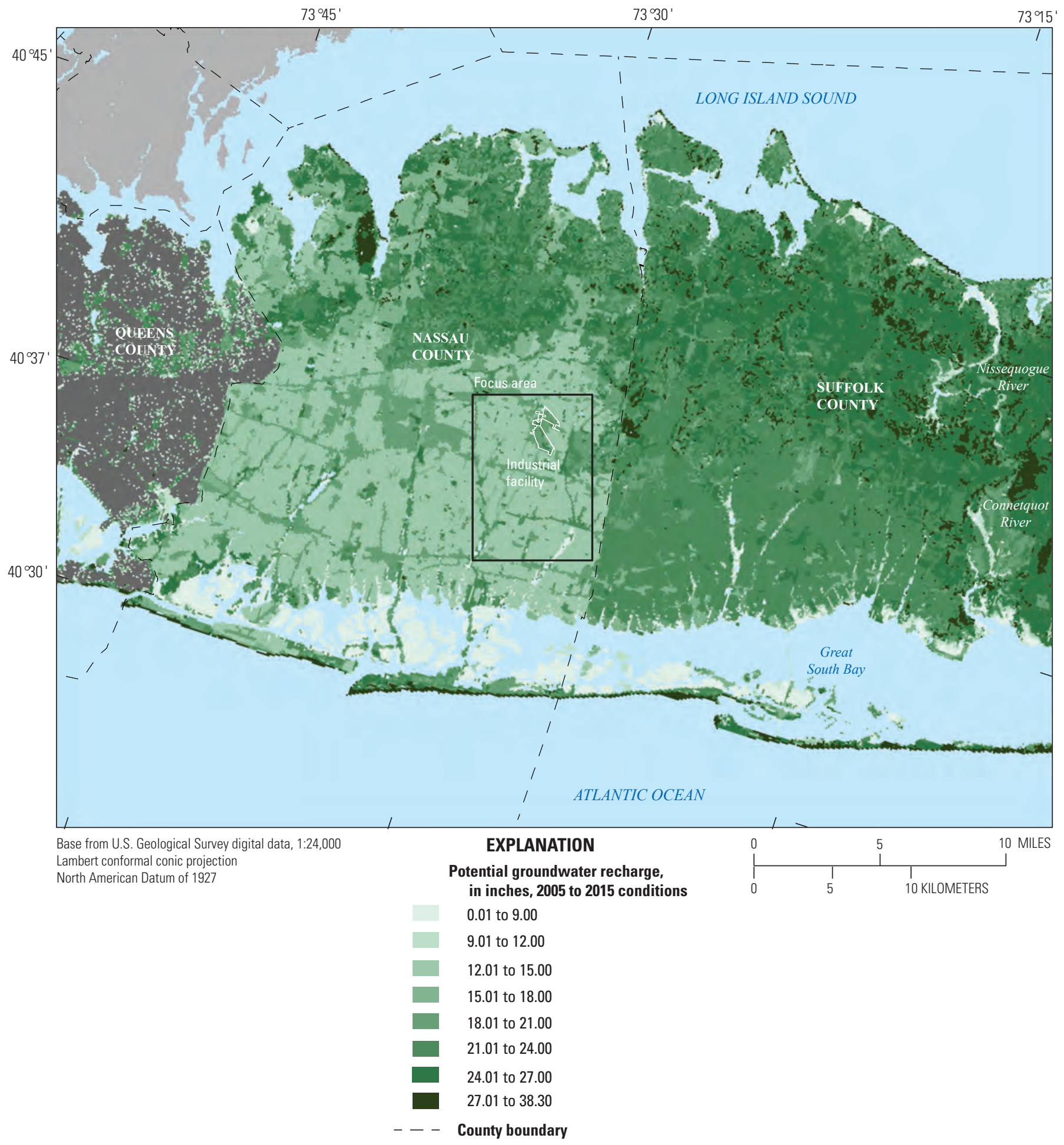

Figure 2.4. Map showing factors affecting model recharge distributions, Long Island, New York. Factors include $A$, recharge from precipitation; $B$, rejected recharge from impervious surfaces; $C$, wastewater return flow; and $D$, leakages from water-supply infrastructure. 


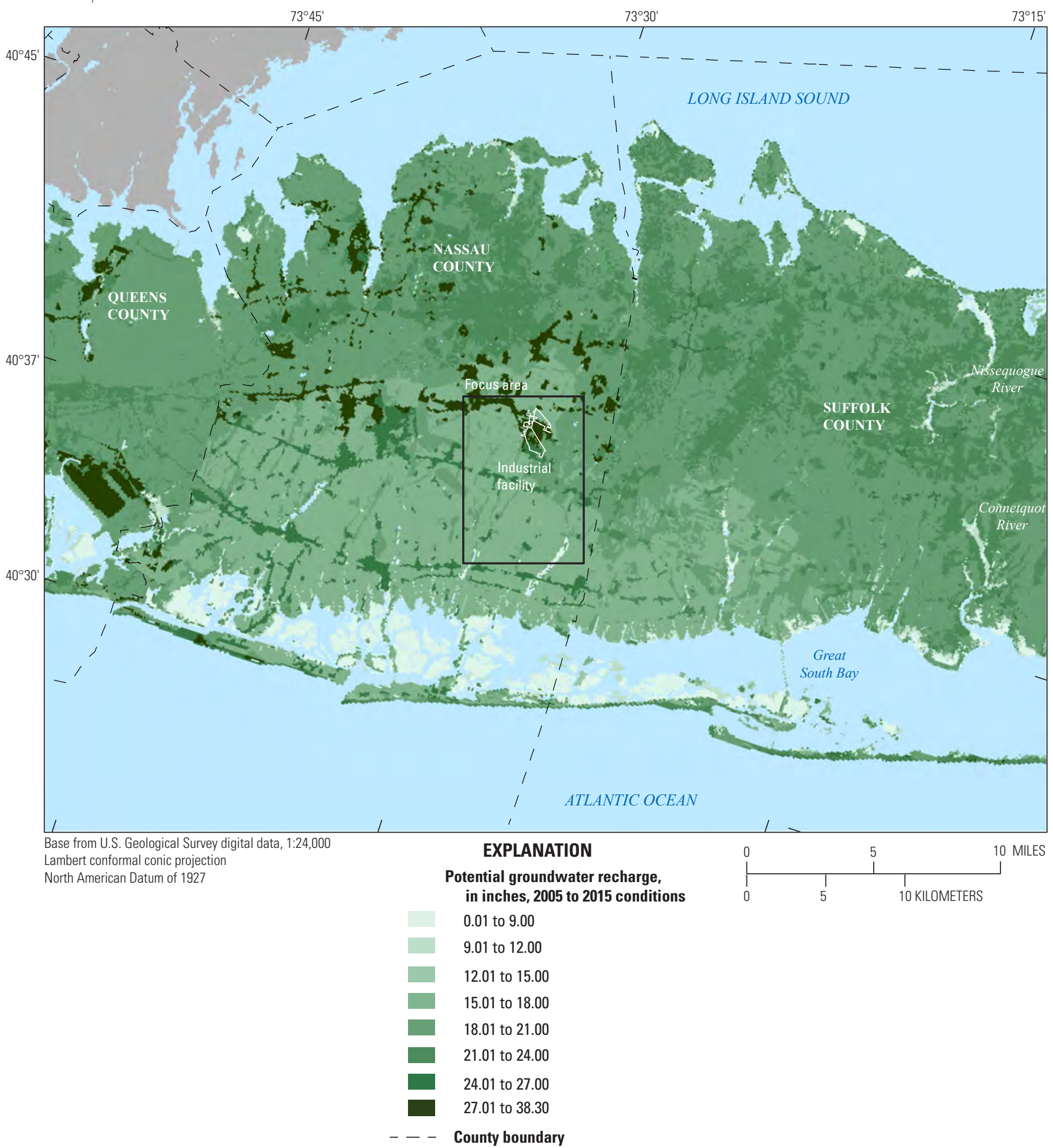

Figure 2.4. - Continued 


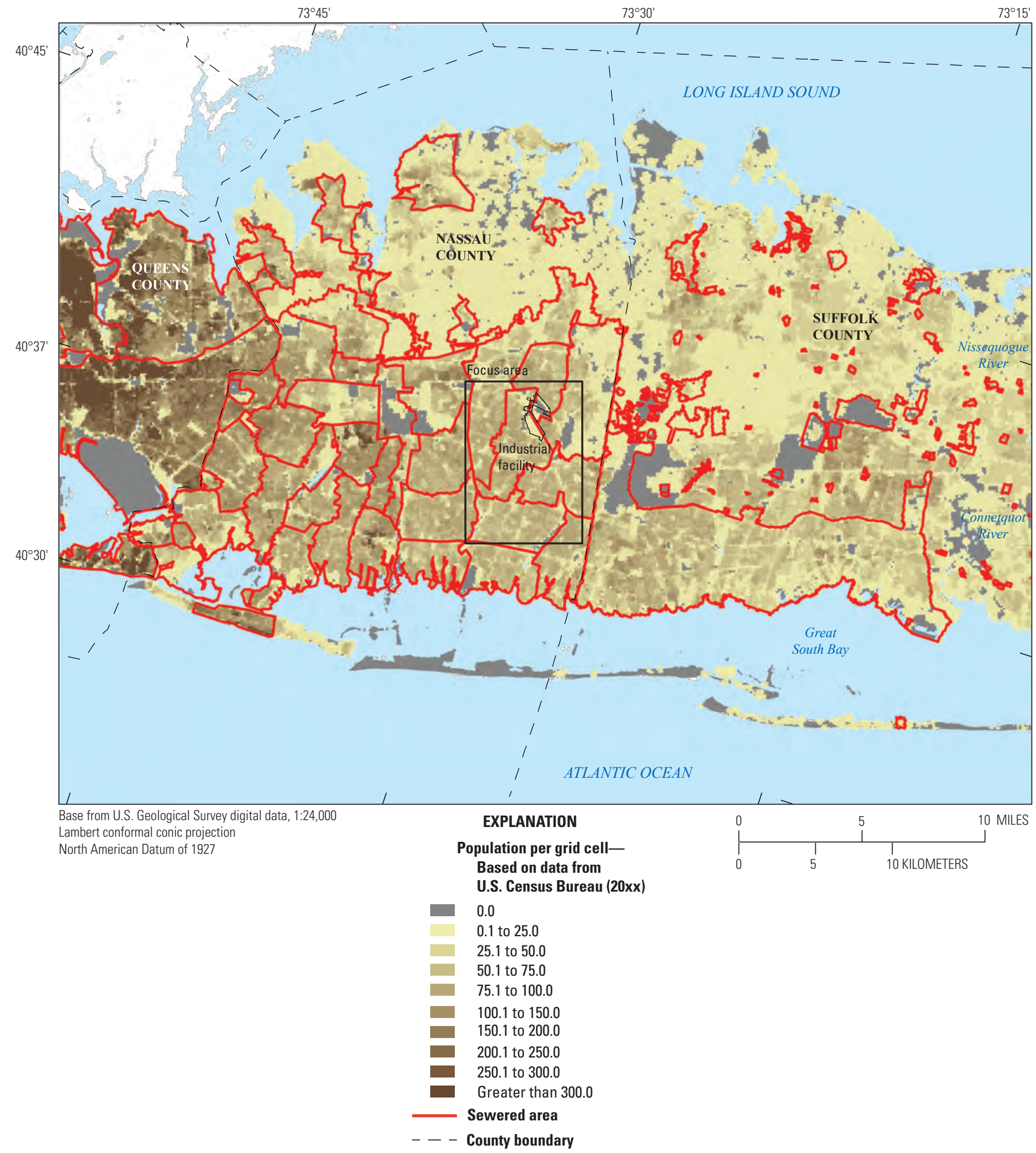

Figure 2.4. - - Continued 


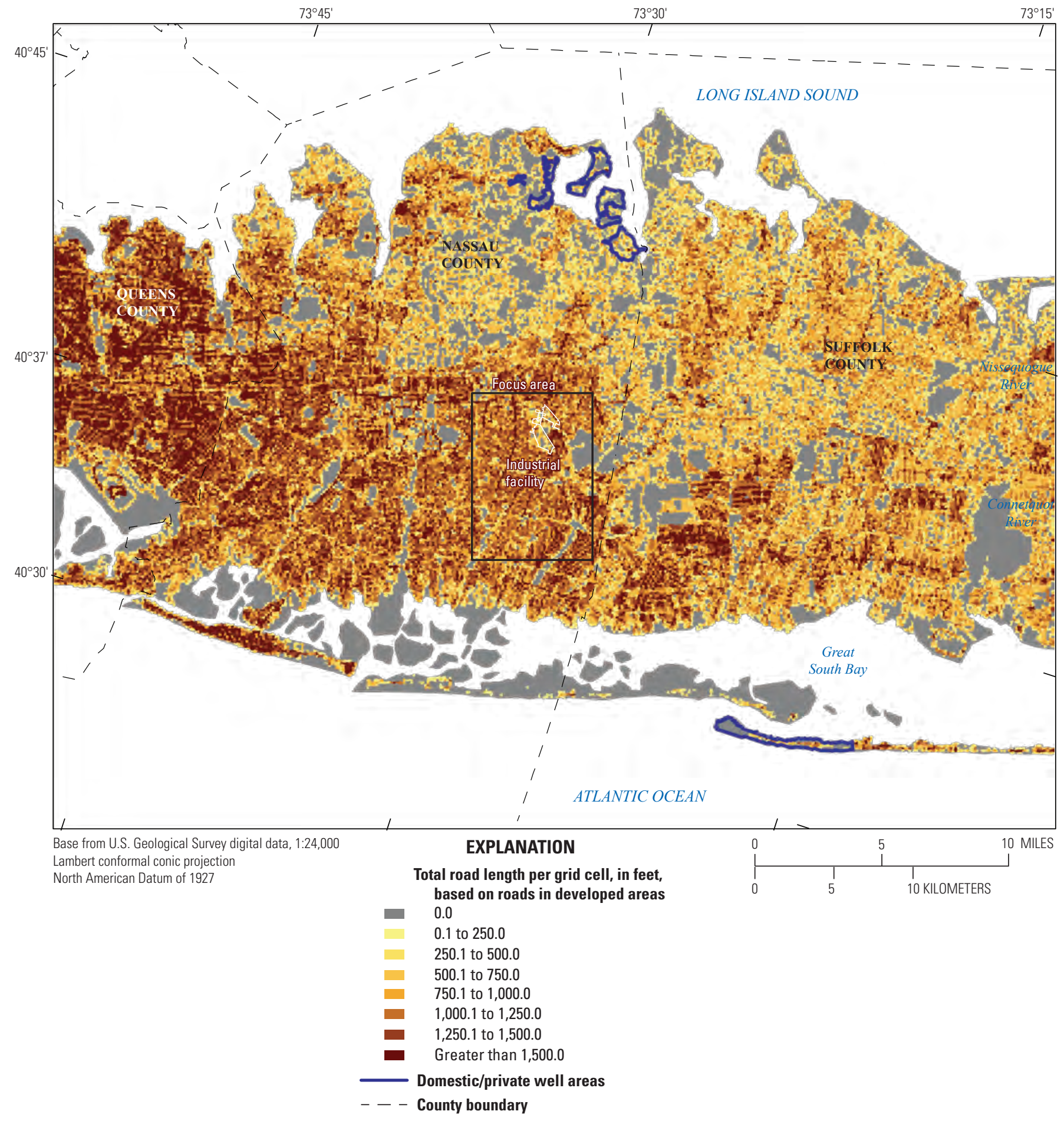

Figure 2.4. - Continued 


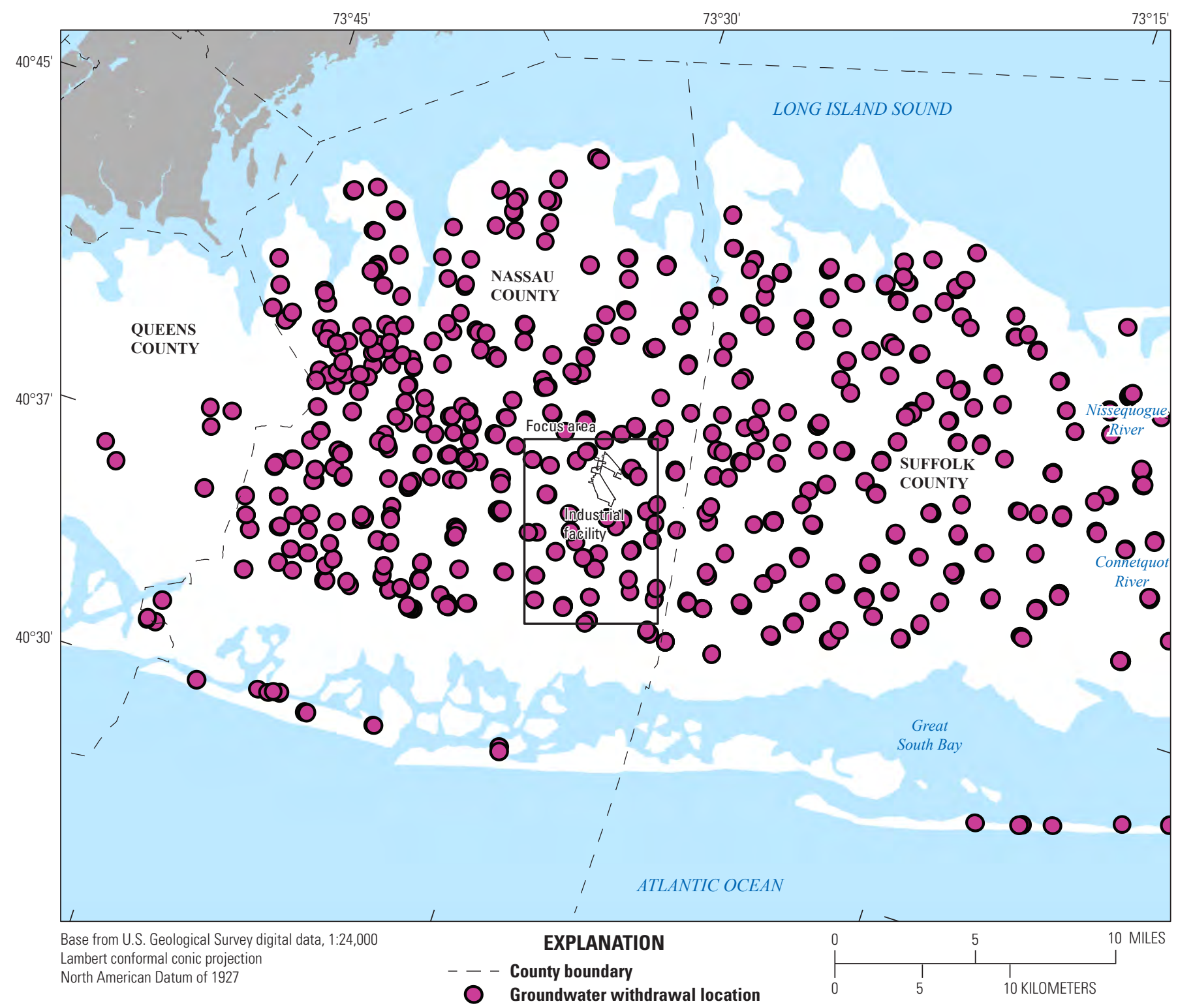

Figure 2.5. Map showing groundwater-withdrawal locations, Long Island, New York. 
A

FEET

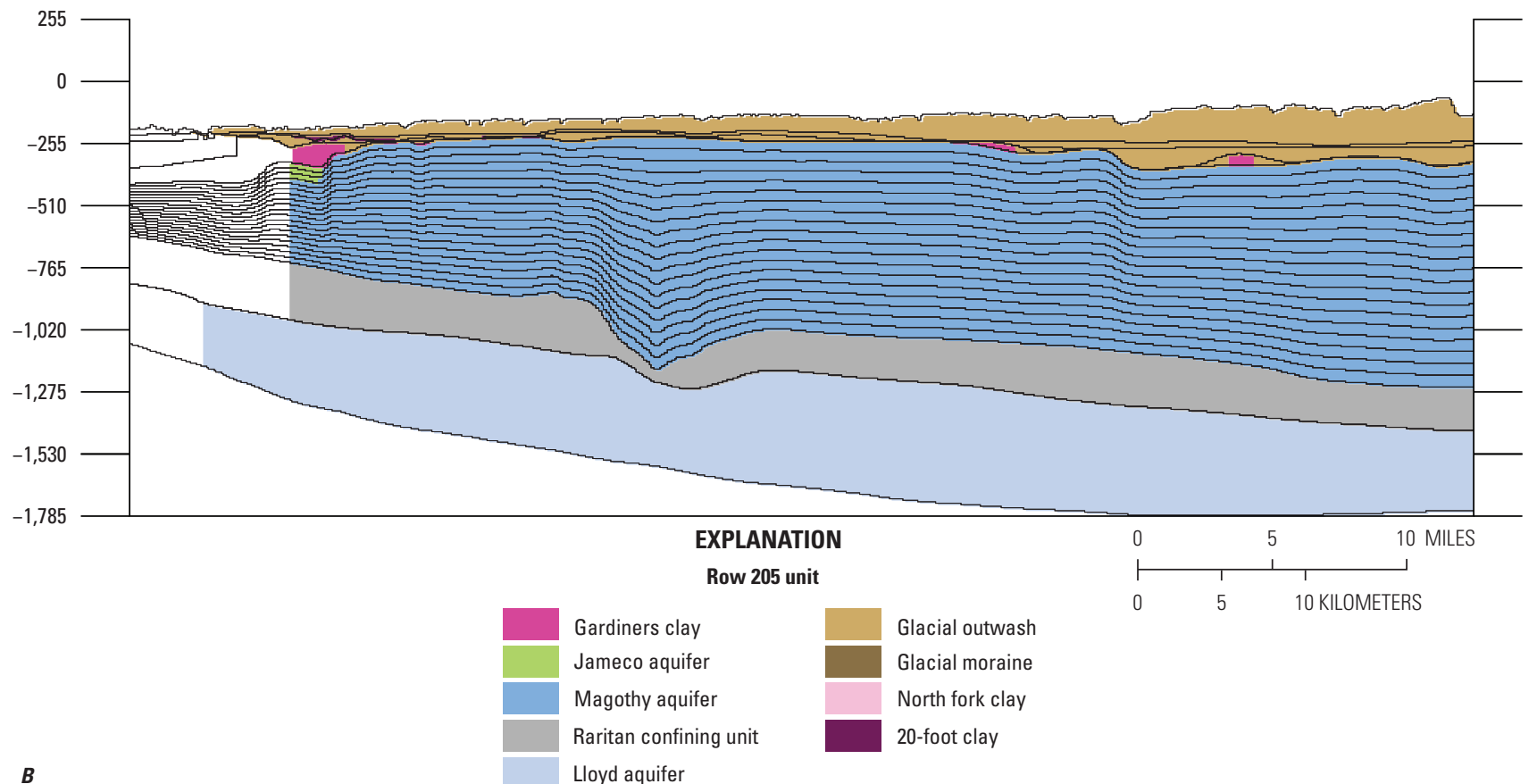

B NORTH

Lloyd aquifer

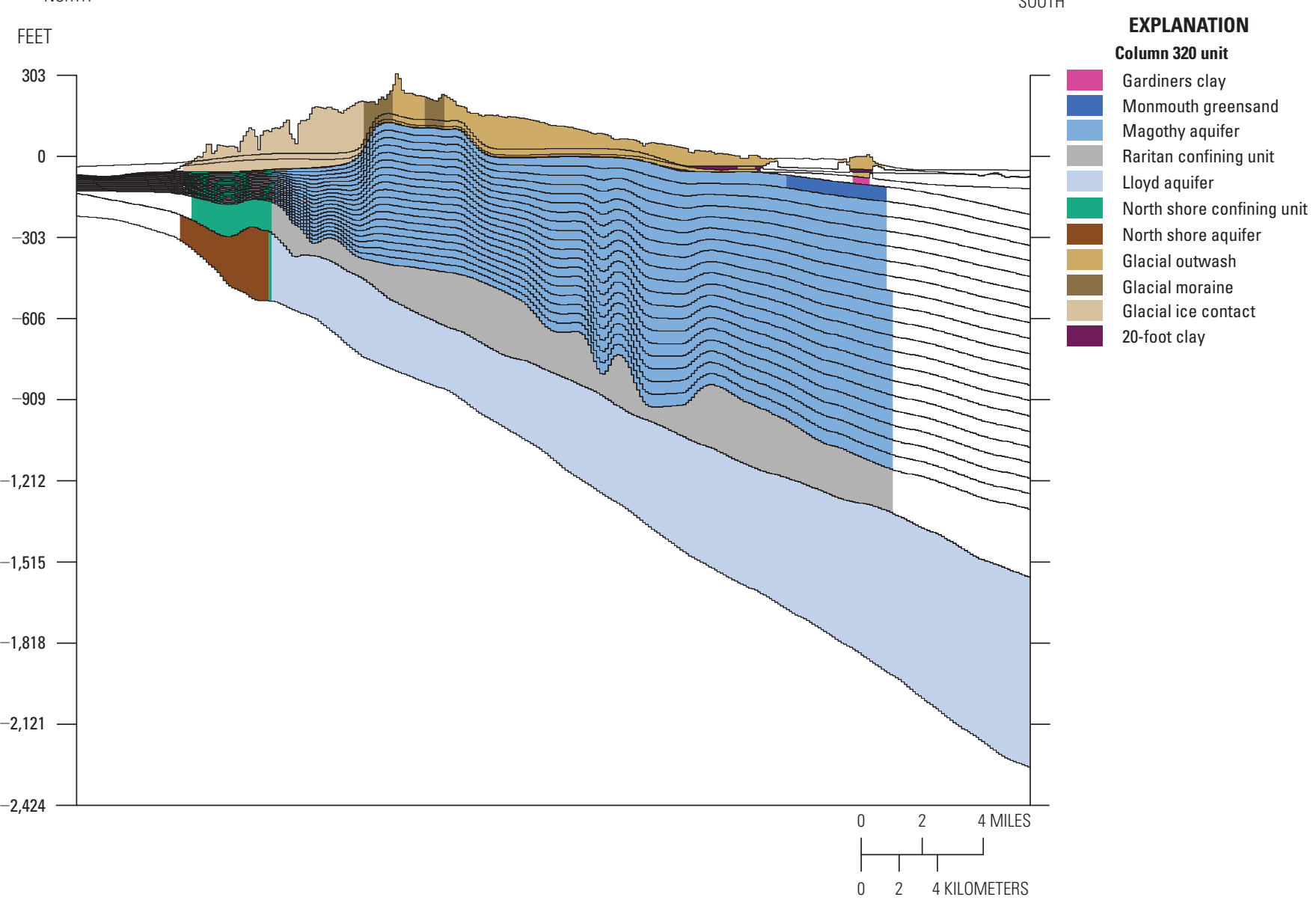

Figure 2.6. $\quad A$, Row and $B$, column sections of a regional model showing hydrogeologic units on Long Island, New York. Locations of sections are shown on figure 2.1. 


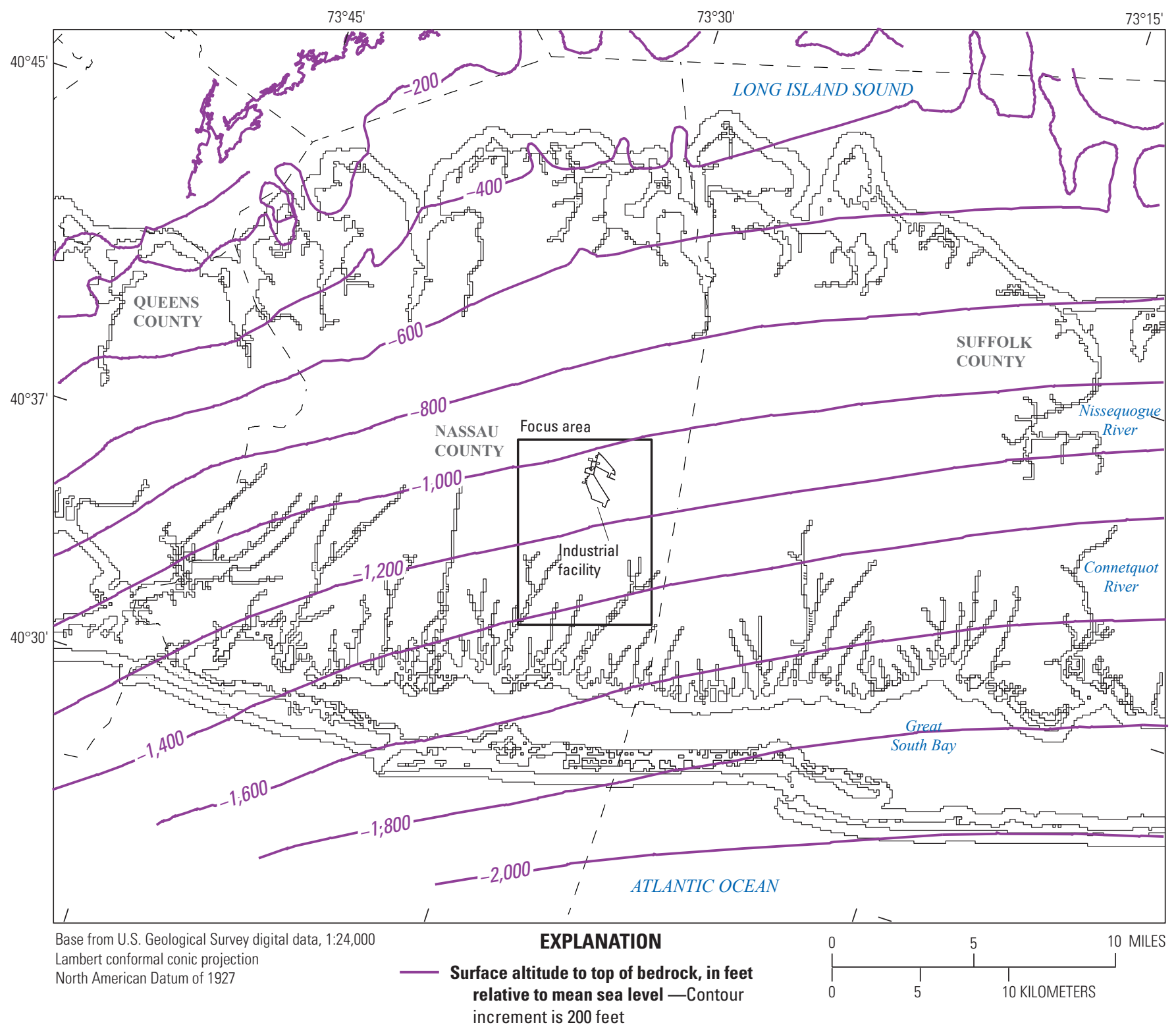

Figure 2.7. Maps showing extents and elevations of top of hydrogeologic units, Long Island, New York; $A$, bedrock; $B$, Lloyd and North Shore aquifers; $C$, Raritan confining unit; $D$, Magothy and Jameco aquifers; $E$, Gardiners clay and North Shore confining unit; $F$, Smithtown and 20-foot clay units. 


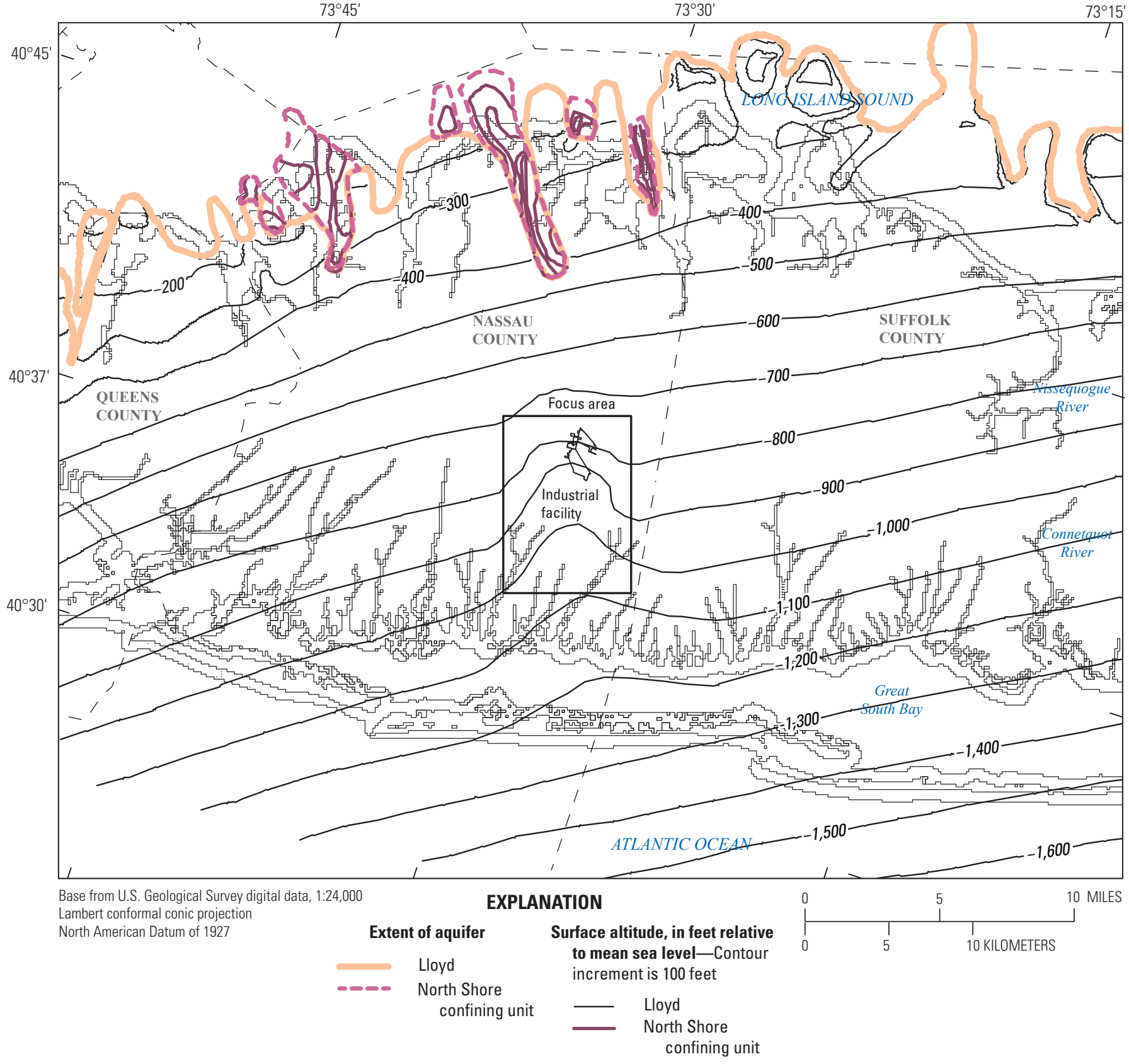

Figure 2.7. - Continued 


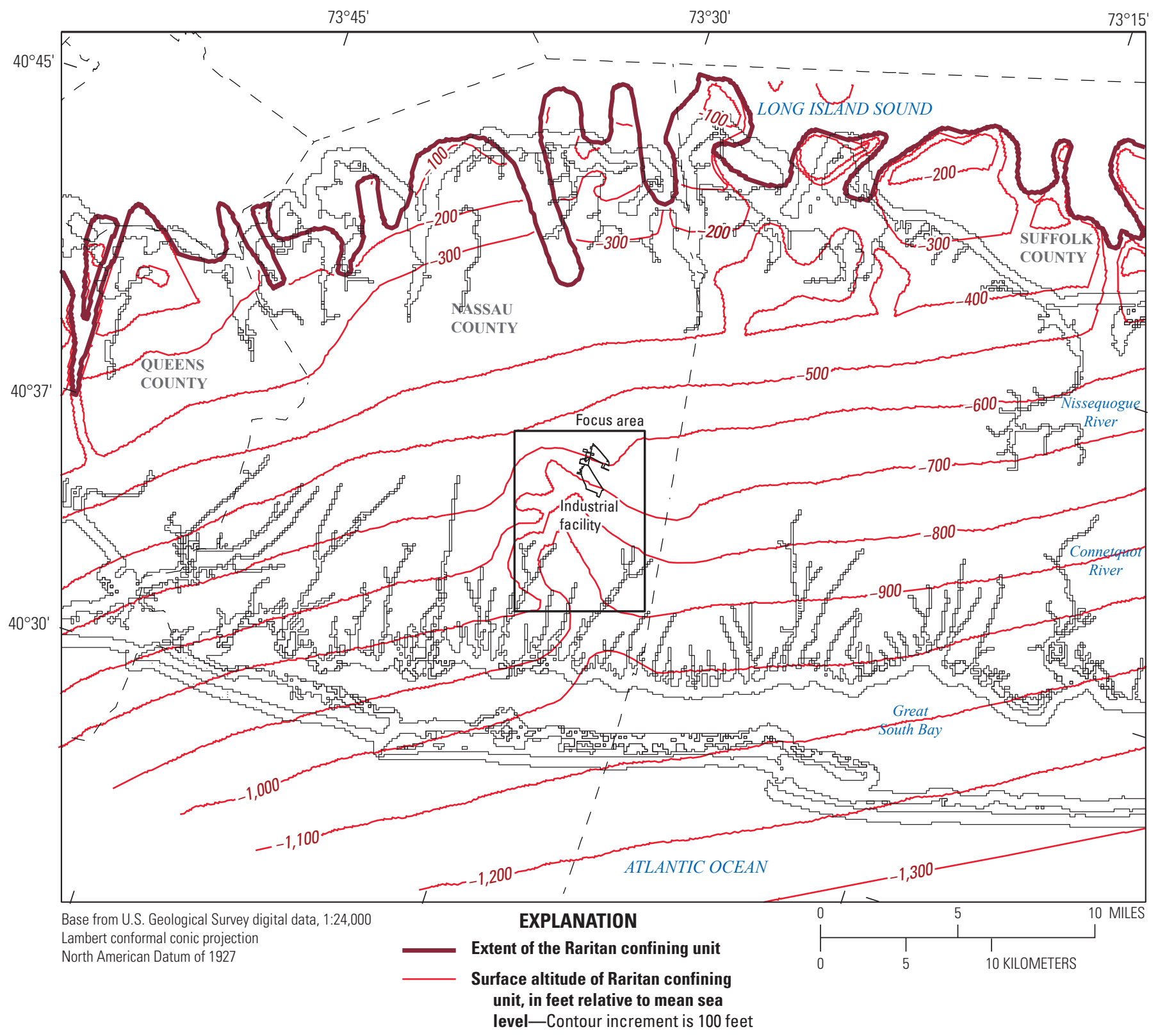

Figure 2.7. - Continued 


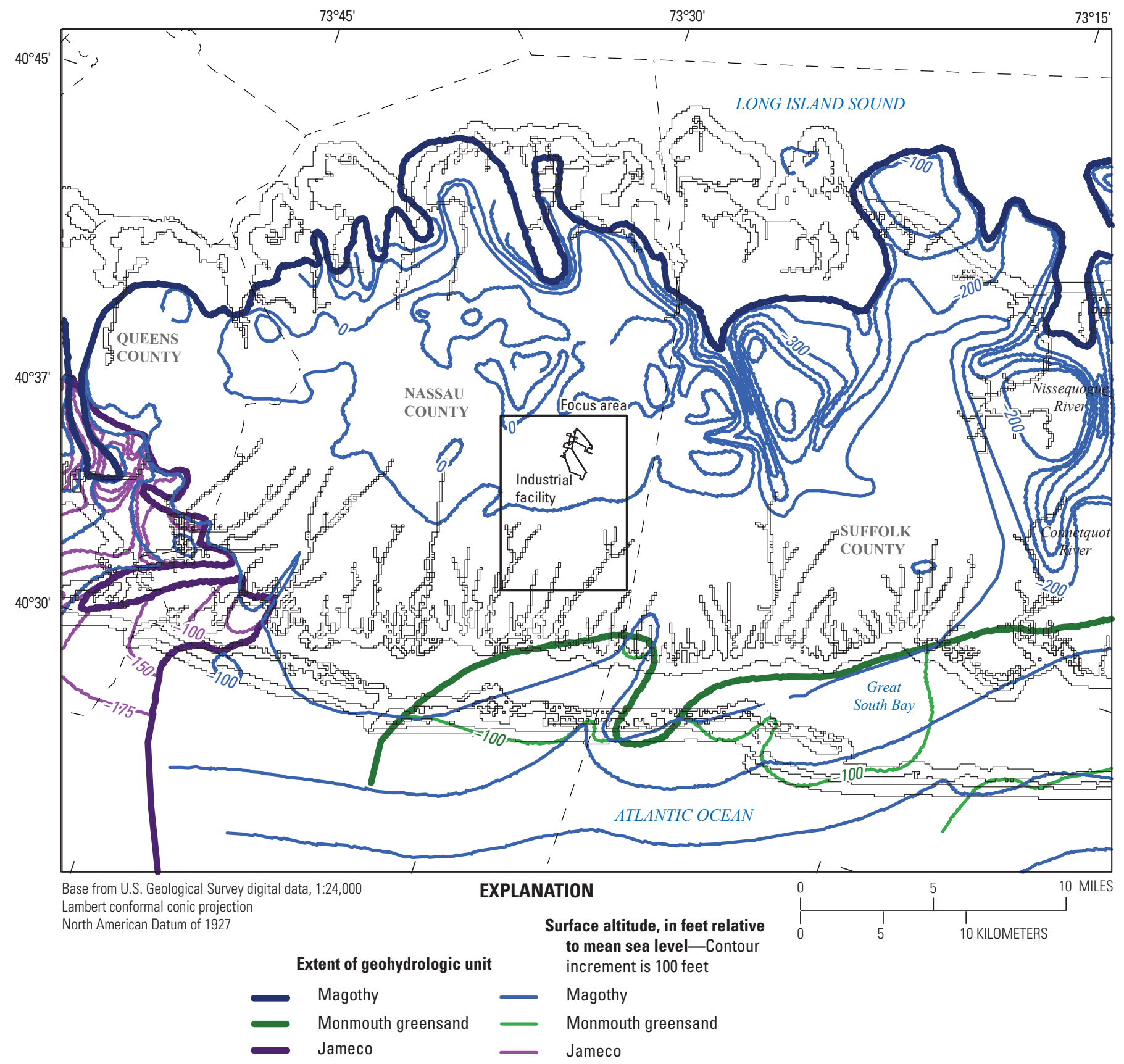

Figure 2.7. - Continued 


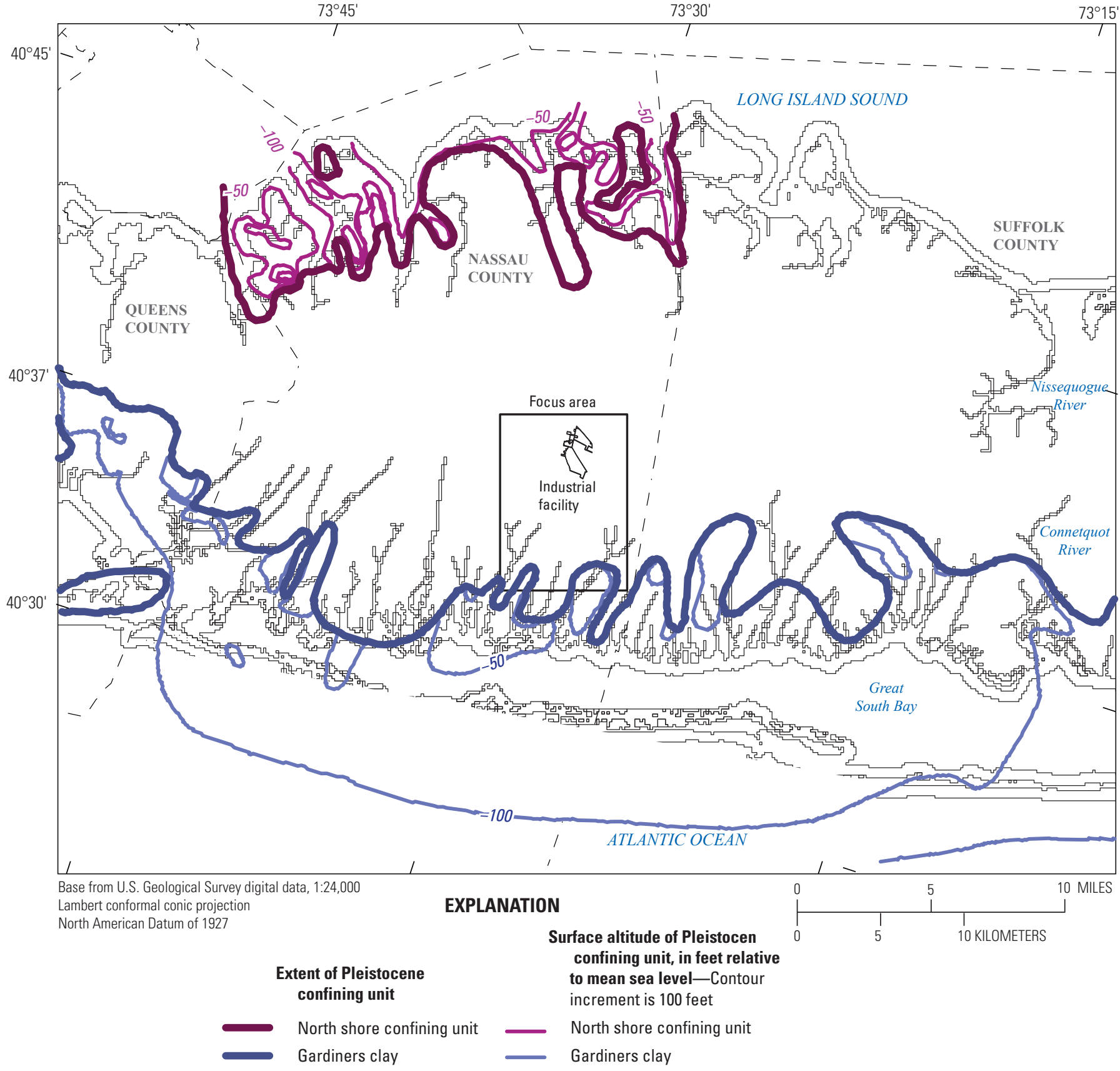

Figure 2.7. -Continued 


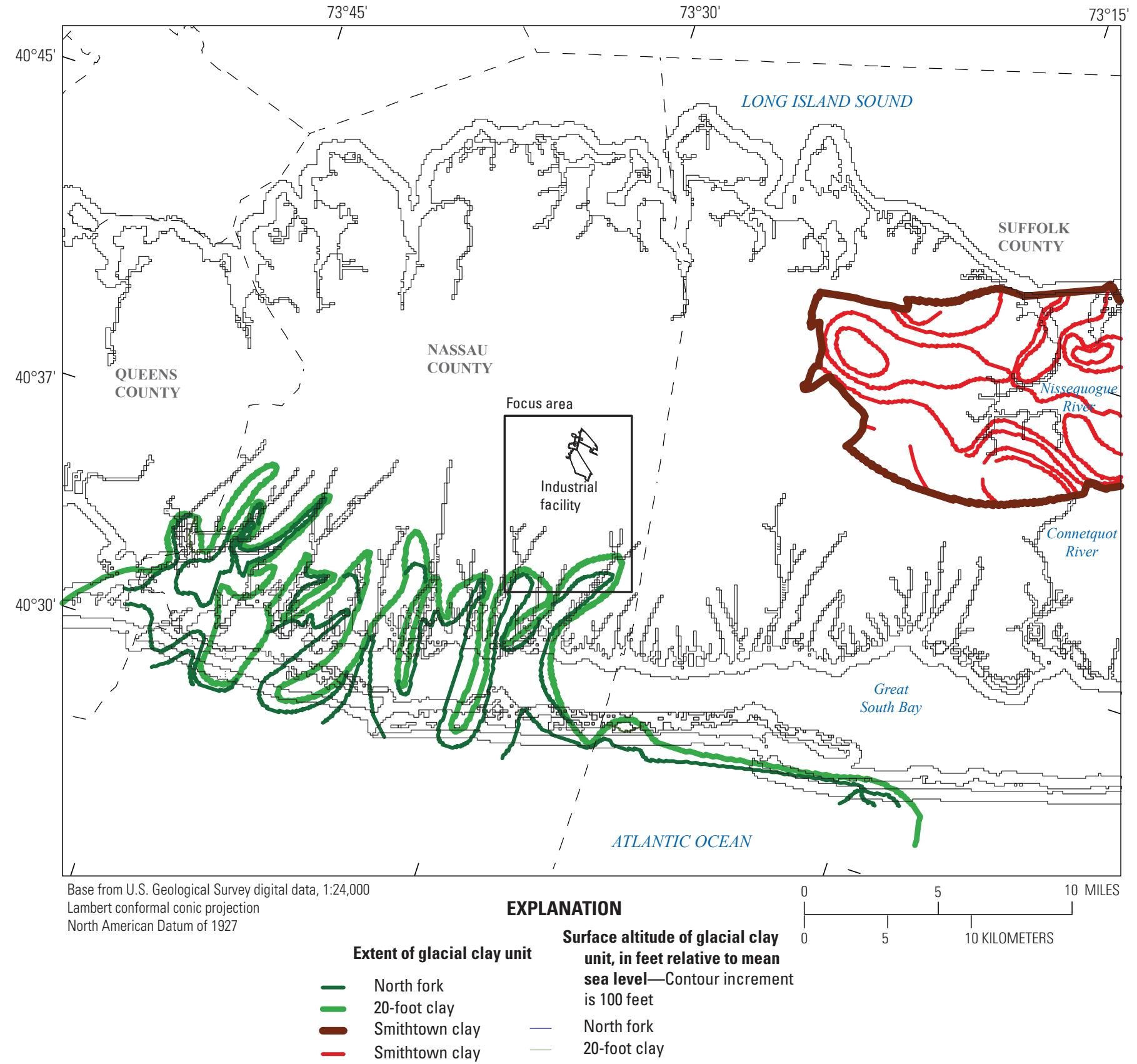

Figure 2.7. - Continued 


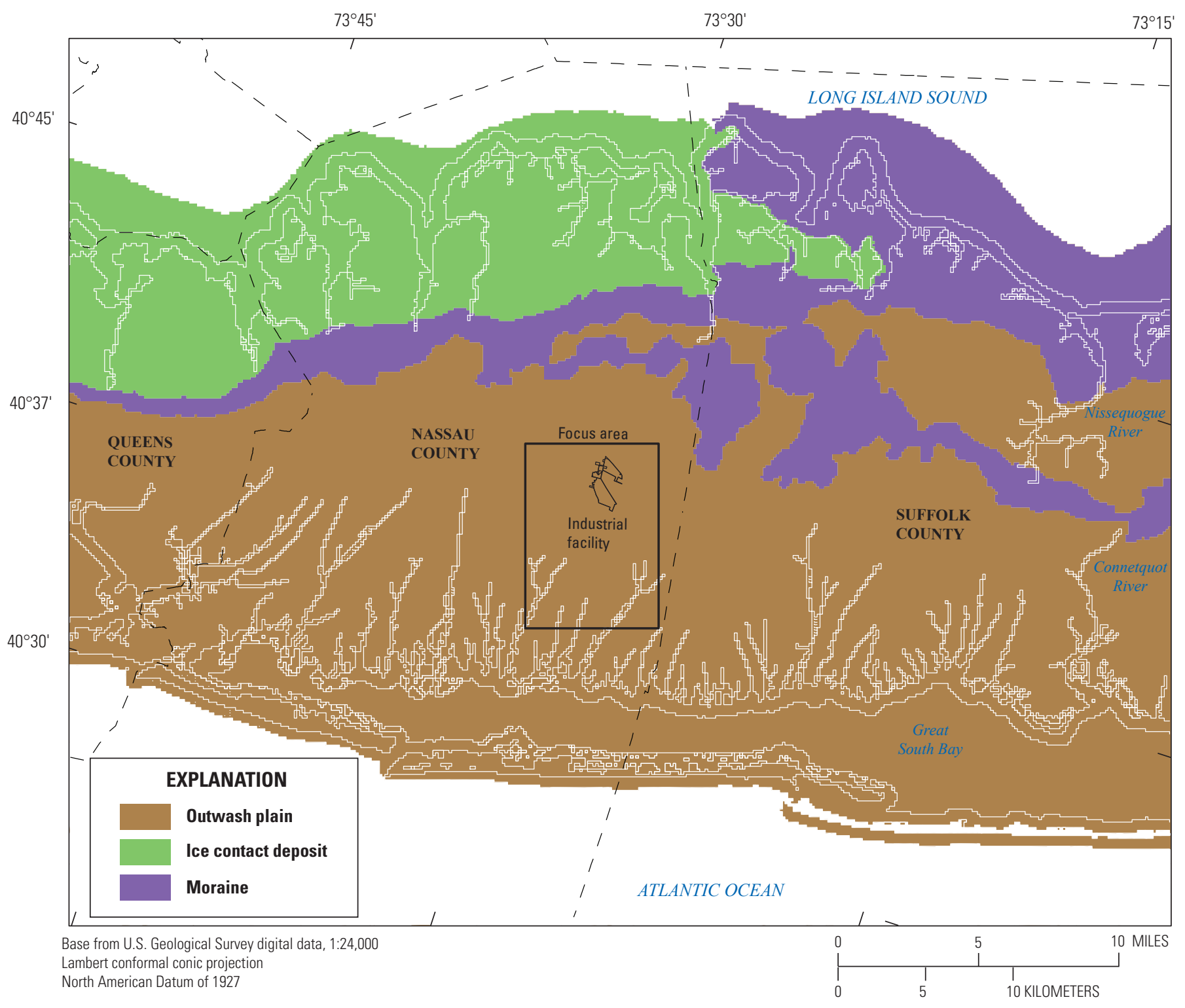

Figure 2.8. Map showing model moraine, ice-contact deposit, and outwash zones, Long Island, New York. Zone parameter values are listed in table 6 of this report. 


\section{References Cited}

Charles, E.G., 2016, Regional chloride distribution in the Northern Atlantic Coastal Plain aquifer system from Long Island, New York, to North Carolina: U.S. Geological Survey Scientific Investigations Report 2016-5034, 37 p., apps., accessed June 4, 2019, at https://doi.org/10.3133/ sir20165034.

Homer, C., Dewitz, J., Fry, J., Coan, M., Hossain, N., Larson, C., Herold, N., McKerrow, A., VanDriel, J.N., and Wickham, J., 2007, Completion of the 2001 national land cover database for the conterminous United States: Photogrammetric Engineering and Remote Sensing, v. 73, no. 4, p. 337-341, accessed June 3, 2019, at http://citeseerx.ist.psu.edu/viewdoc/download?doi= 10.1.1.515.7961\&rep=rep1\&type $=$ pdf.

Homer, C.G., Dewitz, J.A., Yang, L., Jin, S., Danielson, P., Xian, G., Coulston, J., Herold, N.D., Wickham, J.D., and Megown, K., 2015, Completion of the 2011 national land cover database for the conterminous United States-Representing a decade of land cover change information: Photogrammetric Engineering and Remote Sensing, v. 81, no. 5, p. 345-354, June 3, 2019, at https:/www.ingentaconnect.com/content/asprs/pers/2015/ 00000081/00000005/art00002.

Masterson, J.P., and Pope, J.P., Monti, J., Jr., Nardi, M.R., Finkelstein, J.S., and McCoy, K.J., 2015, Hydrogeology and hydrologic conditions of the Northern Atlantic Coastal Plain aquifer system from Long Island, New York, to North Carolina (ver. 1.1, September 2015): U.S. Geological Survey Scientific Investigations Report 2013-5133, 76 p., accessed August 2, 2019, at https://doi.org/10.3133/ sir20135133.

Misut, P.E., 2020, MODFLOW-NWT and MODPATH6 model use to analyze remedial scenarios affecting plume movement through a sole-source aquifer system, southeastern Nassau County, New York: U.S. Geological Survey data release, https://doi.org/10.5066/P9DOBQ8N.

Natural Resources Conservation Service, [undated]a, Soil physical properties, available water capacity: Natural Resources Conservation Service web soil survey, accessed March 28, 2013, at https:/websoilsurvey.sc.egov.usda.gov/ App/WebSoilSurvey.aspx.
Natural Resources Conservation Service, [undated]b, Soil qualities and features, hydrologic soil group: Natural Resources Conservation Service web soil survey, accessed March 28, 2013, at https://websoilsurvey.sc.egov.usda.gov/ App/WebSoilSurvey.aspx.

Smolensky, D.A., Buxton, H.T., and Shernoff, P.T., 1989, Hydrogeologic framework of Long Island, New York: U.S. Geological Survey Hydrologic Atlas 709, 3 sheets, scale 1:250,000. [Also available at https://doi.org/10.3133/ ha709.]

Stumm, F., 1999, Hydrogeology and extent of saltwater intrusion of the Great Neck peninsula, Great Neck, Long Island, New York: U.S. Geological Survey Water-Resources Investigations Report 1999-4280, 41 p., accessed June 23, 2019, at https://doi.org/10.3133/wri994280.

Thornton, M.M., Thornton, P.E., Wei, Y., Vose, R.S., and Boyer, A.G., 2017, Daymet - Station-level inputs and model predicted values for North America, version 3: Oak Ridge National Laboratory dataset, accessed June 4, 2019, https://doi.org/10.3334/ORNLDAAC/1391.

Thornton, P.E., Thornton, M.M., Mayer, B.W., Wilhelmi, N., Wei, Y., Devarakonda, R., and Cook, R.B., 2014, Daymet - Daily surface weather data on a 1-km grid for North America, version 2: Oak Ridge National Laboratory dataset, accessed June 4, 2019, at https://doi.org/10.3334/ ORNLDAAC/1219.

U.S. Census Bureau, 2012, 2010 census of population and housing, population and housing unit counts, $\mathrm{CPH}-2-1$, United States: U.S. Census Bureau website, accessed March 2, 2020, at https:/www.census.gov/library/ publications/2012/dec/cph-2.html.

Walter, D.A., and Finkelstein, J.S., 2020, Distribution of selected hydrogeologic characteristics of the upper glacial and Magothy aquifers, Long Island, New York: U.S. Geological Survey Scientific Investigations Report 2020-5023, 21 p., https://doi.org/10.3133/sir20205023.

Westenbroek, S.M., Kelson, V.A., Dripps, W.R., Hunt, R.J., and Bradbury, K.R., 2010, SWB-A modified Thornthwaite-Mather soil-water-balance code for estimating groundwater recharge: U.S. Geological Survey Techniques and Methods, book 6, chap. A31, 60 p., accessed March 3, 2020, at https://doi.org/10.3133/tm6A31. 

For more information, contact:

Director, New York Water Science Center U.S. Geological Survey

425 Jordan Road

Troy, NY 12180-8349

dc_ny@usgs.gov

or visit our website at https://www.usgs.gov/centers/ny-water

Publishing support provided by the

Pembroke Publishing Service Center 
通 